CAIUÁ MANI PERES

\title{
Gerenciamento costeiro integrado sob uma perspectiva etno-oceanográfica: o conhecimento tradicional na Baía do Araçá
}

\begin{abstract}
Dissertação apresentada ao Instituto Oceanográfico da Universidade de São Paulo como parte dos requisitos para obtenção do título de Mestre em Ciências, Programa de Oceanografia, área de Oceanografia Biológica.
\end{abstract}

Orientador: Prof. Dr. Alexander Turra. 
Universidade de São Paulo

Instituto Oceanográfico

\title{
Gerenciamento costeiro integrado sob uma perspectiva etno-oceanográfica: o conhecimento tradicional na Baía do Araçá
}

\author{
Caiuá Mani Peres
}

Dissertação apresentada ao Instituto Oceanográfico da Universidade de São Paulo como parte dos requisitos para obtenção do título de Mestre em Ciências, Programa de Oceanografia, área de Oceanografia Biológica.

Julgada em

$\operatorname{Prof}(\mathrm{a}) . \operatorname{Dr}(\mathrm{a})$.

Conceito

$\operatorname{Prof}(\mathrm{a}) . \operatorname{Dr}(\mathrm{a})$.

Conceito

$\operatorname{Prof}(\mathrm{a}) . \operatorname{Dr}(\mathrm{a})$.

Conceito

São Paulo 


\section{SUMÁRIO}

SUMÁRIO

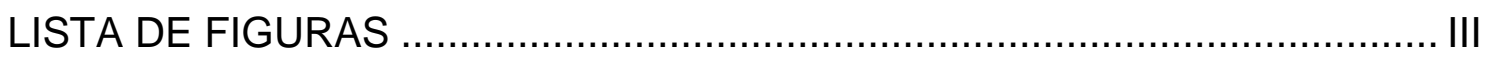

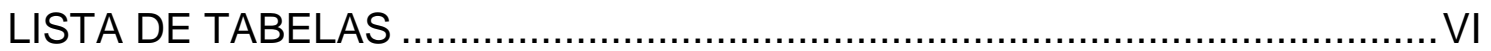

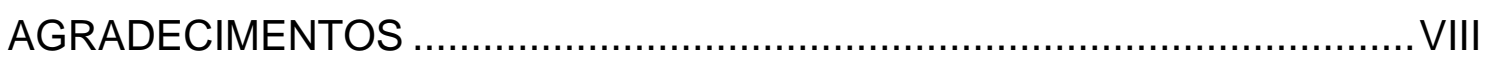

RESUMO

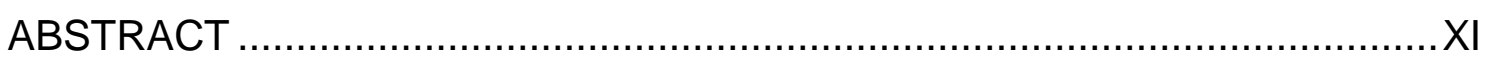

INTRODUÇÃO

O GERENCIAMENTO COSTEIRO INTEGRADO (GCI) ............................ 5

O GERENCIAMENTO COSTEIRO NO BRASIL E O PNGC …................... 8

A PARTICIPAÇÃO DAS "COMUNIDADES" NA GESTÃO DOS ESPAÇOS E

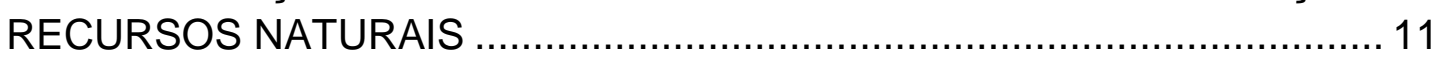

POPULAÇÕES E TERRITÓRIOS TRADICIONAIS .................................... 14

O EXEMPLO DAS COMUNIDADES CAIÇARAS E SUA INSERÇÃO NO

"AMBIENTE" URBANO................................................................. 16

O CONHECIMENTO TRADICIONAL (CT) NA GESTÃO COSTEIRA .......... 17

A ABORDAGEM ETNOOCEANOGRÁFICA ............................................ 19

MODELOS CONCEITUAIS (FRAMEWORKS) COMO SUPORTE A GESTÃO

A BAÍA DO ARAĆ́ (SÃO SEBASTIÃO-SP)

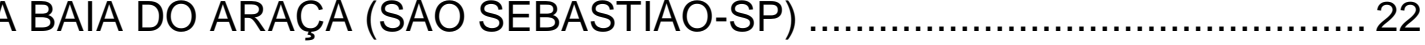

Histórico de ocupação e de transformações do Araçá ................................. 27

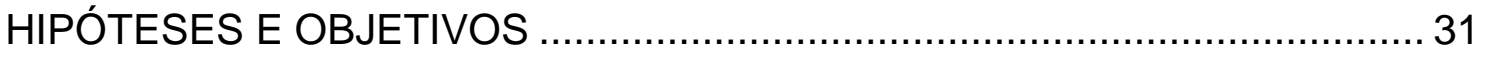

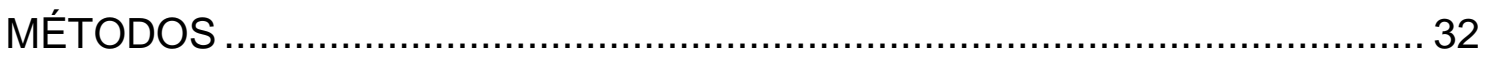

Métodos de seleção e identificação dos atores-alvo ................................ 32

Métodos de aquisição e registro das informações ................................... 33

Métodos de análise das informações ................................................... 35

Aplicação dos modelos de planejamento SWOT e DPSIR ………........... 37

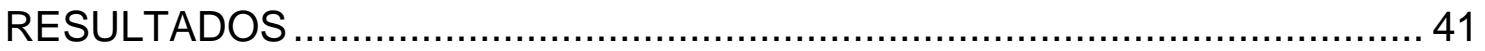

OS PESCADORES E A PESCA NO ARAÇÁ …………............................. 41

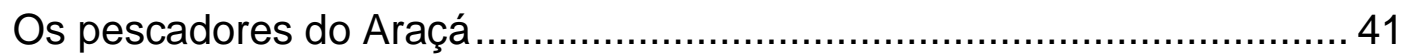

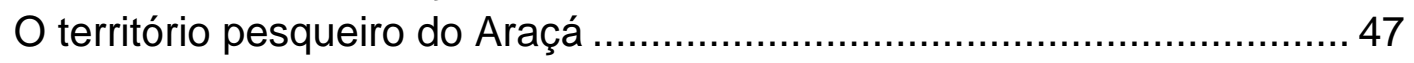

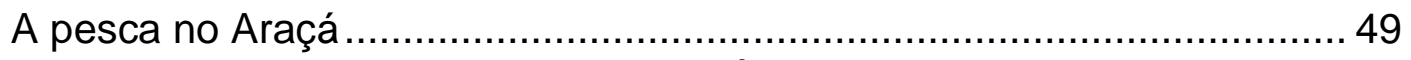

O CONHECIMENTO ETNOOCEANOGRÁFICO DOS PESCADORES DO

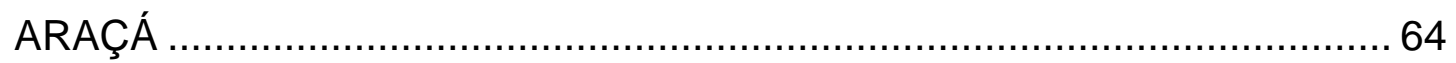

A biodiversidade - etnoespécies da fauna aquática do Araçá ................... 64

A influência de fenômenos físico-oceanográficos na pesca....................... 79

OPINIÕES E CONTRIBUIÇÕES PARA A GESTÃO LOCAL.......................... 85

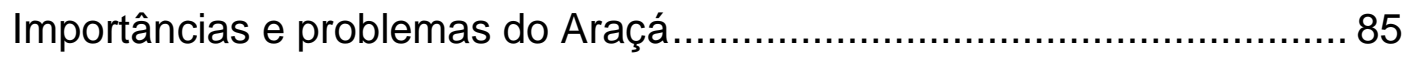

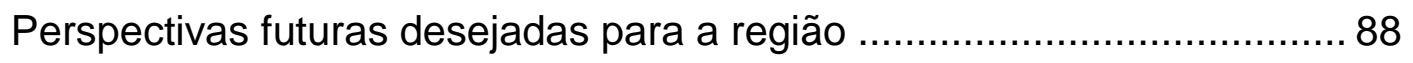

A análise SWOT e o DPSIR framework ................................................. 91

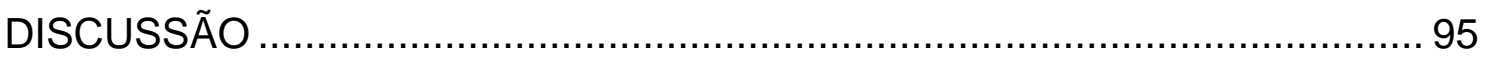

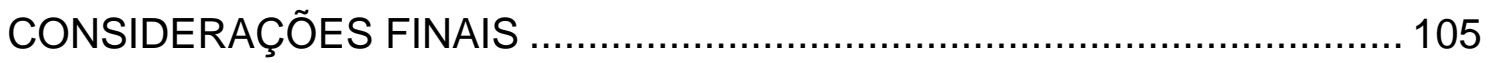


REFERÊNCIAS

107

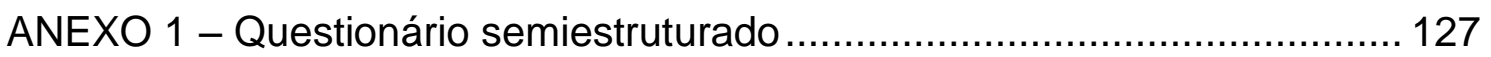

ANEXO 2 - Termo de consentimento …...................................................... 133

ANEXO 3 - Mapa da Baía do Araçá contendo apenas a linha de costa ........ 134 


\section{LISTA DE FIGURAS}

FIGURA 1: Etapas do processo de $\mathrm{GCl}$, representadas em loopings (ciclos que se repetem)

FIGURA 2: Localização da área de estudo. Em destaque: o Litoral Norte do Estado de São Paulo e a Baía do Araçá 23

FIGURA 3: Região da Baía do Araçá e seu entorno urbanizado, com destaque para o Porto de São Sebastião, TEBAR, Rodovia Rio-Santos (SP-055) e para o Emissário Submarino do Araçá 26

FIGURA 4: Projeto de construção do cais do Porto de São Sebastião executado durante a década de 1940, com destaque para a linha de costa original e para o cais do porto

FIGURA 5: Proposta de ampliação do Porto de São Sebastião apresentada pela Companhia Docas de São Sebastião, em 2011 29

FIGURA 6: Diferentes mapas (A, B, C e D) desenhados pelos pescadores do Araçá 35

FIGURA 7: Esquema de organização da matriz SWOT 38

FIGURA 8: Estrutura do modelo conceitual DPSIR 39

FIGURA 9: Localização da Baía do Araçá, dos bairros Varadouro e Topolândia, da Rodovia Rio-Santos, do Porto de São Sebastião e do TEBAR

FIGURA 10: Canoas caiçaras dos pescadores da Baía do Araçá 44

FIGURA 11: Fogão a lenha e mariscos sendo preparados ao modo tradicional caiçara, na casa de um dos pescadores entrevistados 44 
FIGURA 12: Distribuição dos entrevistados $(n=18)$ segundo: (A) classes de idade; (B) grau de escolaridade (completo ou incompleto); (C) classe de renda média bruta mensal declarada (em função do salário mínimo); e (D) relação econômica com a atividade pesqueira

FIGURA 13: Delimitação aproximada do território pesqueiro dos pescadores da Baía do Araçá, estabelecido a partir dos mapas falados, com destaque para a localização da Ponta do Araçá, da Praia Preta e do Farol do Moleque

FIGURA 14: Samburá - cesto para armazenar o camarão vivo usado por um dos pescadores entrevistados 51

FIGURA 15: Redes de espera de diferentes tamanhos e malhas utilizadas na pesca no Araçá 53

FIGURA 16: Puçás feitos artesanalmente pelos próprios pescadores e utilizados na pesca do camarão (para usá-los como isca viva) 54

FIGURA 17: Ponta da fisga na forma de tridente em detalhe, e fisga sendo utilizada para captura do siri 54

FIGURA 18: Canoas a remo e pequenas lanchas dos pescadores do Araçá, guardadas nos quintais de suas casas 12

FIGURA 19: Canoas dos pescadores locais. A primeira, localizada em uma das praias da baía, e a segunda, fundeada em uma área abrigada 56

FIGURA 20: Distribuição dos entrevistados $(n=18)$ segundo a regularidade aproximada com que costumam pescar no Araçá 
FIGURA 21: Principais etnoespécies alvo capturadas no território pesqueiro dos pescadores do Araçá

FIGURA 22: Padrões preferenciais de ocupação dos habitats (zonas ecológicas) pelos peixes capturadas no território pesqueiro do Araçá 73

FIGURA 23: Representação das estratégias de predação de algumas etnoespécies de peixes a partir das representações descritas pelos pescadores: peixes menores circulam pela baía (trajetos simbolizados por flechas) durante a maré alta, enquanto os predadores (maiores) os seguem ou aguardam sua passagem próximo a Ponta do Araçá 75

FIGURA 24: Localização dos habitats aquáticos das 6 principais etnoespécies de invertebrados, capturadas pelos pescadores no território pesqueiro do Araçá 78

FIGURA 25: Águas de sul e águas de leste representadas por flechas em azul e amarelo, respectivamente, orientadas segundo a descrição dos pescadores entrevistados 82

FIGURA 26: A revessa de maré no interior da Baía do Araçá (simbolizada por flechas em azul e amarelo) representada tanto durante o regime de águas de sul, como durante o regime de águas de leste, conforme a descrição dos pescadores entrevistados 84

FIGURA 27: DPSIR/Araçá - aplicação do modelo DPSIR para a Baía do Araçá (com base nas informações obtidas a partir do CT e das percepções dos pescadores entrevistados) exemplificando as relações entre causas e consequências dos problemas ambientais locais 94 


\section{LISTA DE TABELAS}

TABELA 1: Exemplos de estratégias de gestão dos espaços e recursos naturais, que levam em consideração a participação social e $\quad 0$ compartilhamento de responsabilidades, no contexto da gestão integrada

TABELA 2: Principais estratégias/artes de pesca utilizadas pelos pescadores da Baía do Araçá .....

52

TABELA 3: Principais causas responsáveis por mudanças na pesca, segundo a opinião dos pescadores entrevistados 60

TABELA 4: Etnoespécies da fauna aquática encontradas no território pesqueiro do Araçá e citadas pelos pescadores entrevistados 65

TABELA 5: Etnoespécies que, segundo os pescadores, usam a área interna da Baía do Araçá como um local de reprodução e desenvolvimento nas fases iniciais de vida

TABELA 6: Padrões de comportamento e de ocupação dos habitats (zonas ecológicas) das principais etnoespécies de peixes capturadas no Araçá 72

TABELA 7: Habitats preferenciais das principais etnoespécies de invertebrados capturadas pelos pescadores no Araçá 77

TABELA 8: Condições de altura da maré mais favoráveis para a captura das principais etnoespécies de invertebrados capturadas no Araçá 80

TABELA 9: Características das águas de sul em comparação as das águas de 
leste, segundo os pescadores do Araçá

TABELA 10: Importâncias atribuídas a Baía do Araçá pelos pescadores entrevistados

TABELA 11: Problemas do Araçá segundo a opinião dos pescadores entrevistados 87

TABELA 12: SWOT/Araçá - resultados da aplicação do modelo conceitual intitulado Análise SWOT 92 


\section{AGRADECIMENTOS}

Ao Instituto Oceanográfico da Universidade de São Paulo (IOUSP) pela estrutura física, de recursos humanos e por todo apoio institucional necessário para a realização desse trabalho.

Ao Centro de Biologia Marinha da universidade de São Paulo (CEBIMar/USP), pelo apoio logístico prestado.

A Fundação de Amparo a Pesquisa do Estado de São Paulo (FAPESP) pelo auxílio financeiro vinculado ao Projeto Biota Araçá (2011/50317-5).

A Coordenação de Aperfeiçoamento de Pessoal de Nível Superior (CAPES) pela bolsa que me foi concedida.

A toda equipe do Módulo 10 do Projeto Biota Araçá por todos os momentos enriquecedores compartilhados ao longo de todo esse projeto.

Ao todos do Laboratório de Manejo Ecologia e Conservação Marinha (LabManejo/IOUSP), pelo apoio, pelos momentos de bate-papo e cafézinho, pelas trocas de ideias e por todos os momentos seja de trabalho ou descontração que passamos.

A todos os pescadores da Baía do Araçá que cederam seu tempo e seus saberes tão gentilmente e colaborativamente ao participar dessa pesquisa.

A Dra. Fernanda T. Stori, pela co-orientação, por toda ajuda e parceria estabelecida nas atividades de campo, reuniões e conversas que muito me ajudaram nesse trabalho.

Ao meu orientador Prof. Alexander Turra, por todo apoio, suporte, conselhos, bate-papos inspiradores e pela parceria que construímos desde quando comecei meu estágio ainda na graduação.

A meus amigos de faculdade, do CRUSP, do Fut-Campo/ICBIÓ, de Araraquara e de muitos outros lugares, os quais não vou citar nomes pois posso me esquecer de alguém e acabar cometendo alguma injustiça.

A meus pais André e Lu, sem os quais eu nunca poderia ter chegado até aqui.

E, por fim, gostaria de agradecer a minha amada Marina Santana que sempre esteve ao meu lado pro que der e vier, na alegria ou na tristeza, que sempre me encorajou nos momentos de necessidade e que, acima de tudo, foi, 
é e será por toda minha vida a minha musa inspiradora. 


\section{RESUMO}

O conhecimento tradicional (CT) das populações costeiras pode ser fundamental para a Gestão Costeira Integrada (GCl), pois é de base empírica e combina informações sobre o comportamento dos organismos marinhos e sua taxonomia, processos físicos-oceanográficos, métodos tradicionais de manejo dos recursos naturais, etc. O principal objetivo desse trabalho foi compreender o CT de pescadores artesanais da Baía do Araçá e aplica-lo à gestão costeira através de entrevistas semi-estruturadas conjuntamente com a composição de mapas etnográficos e da sistematização das informações adquiridas. As informações etno-oceanográficas levantadas também foram aplicadas a dois modelos conceituais de orientação para o desenvolvimento de estratégias de gestão local, amplamente utilizados na gestão, a análise SWOT e o DPSIR. A Baía do Araçá é palco de conflitos e impactos que comumente influenciam a qualidade das regiões costeiras e suas relações socioambientais, havendo uma forte necessidade de planejamento do uso do território e, assim, servindo como exemplo para outras localidades. Ao todo, 18 pescadores foram identificados como informantes e entrevistados. Todos demonstraram ter afinidade com a Baía do Araçá e atribuíram ao local uma grande importância para a manutenção de seu modo de vida. Na pesca, foi verificado que a utilização de diferentes estratégias e equipamentos varia conforme as condições do mar e do tempo, espécies-alvo, locais de pesca e de acordo com os saberes e habilidades que cada um possui. De modo geral, os pescadores demonstraram ser "local experts", possuindo elevado conhecimento do ambiente que utilizam tanto para sobrevivência como para reprodução sociocultural de seu modo de vida caiçara. As análises SWOT e do DPSIR contribuíram para a sistematização do CT levantado, possibilitando sua utilização por gestores e sua aplicação para o planejamento local. Recomendase que esse saber e a participação dos pescadores na tomada de decisão sejam considerados na planificação de políticas de gestão dos espaços e recursos naturais costeiro-marinhos.

Palavras-chave: Baía do Araçá; Gerenciamento Costeiro Integrado; Etnooceanografia; Conhecimento tradicional. 


\section{ABSTRACT}

The traditional knowledge (TK) of coastal populations may be fundamental to Integrated Coastal Management (ICG), as it is based on empirical practices and combines information about the behavior of marine organisms and their taxonomy, physical-oceanographic processes, traditional methods of natural resource management, etc. The major aim of this work was to understand the TK of artisanal fishermen from Araçá Bay and apply it to coastal management through semi-structured interviews along with the composition of ethnographic maps and the systematization of the acquired information. The ethnooceanographic information obtained was also applied in two conceptual models, widely used in management, that can guideline the development of local management strategies: the SWOT analysis and DPSIR. Araçá Bay has a scene of multiple conflicts and impacts that commonly influence the quality of coastal regions and their socio-environmental relations, outstanding the important need to plan the use of this territory. Thus the study area serve as an example for other localities. In total, 18 fishermen were identified as informants and were interviewed. All of them demonstrated affinity with Araçá Bay and attribute to this place a great importance for the maintenance of their way of life. For fishing, it was verified that the use of different strategies and equipment varies according to the conditions of the sea and of the weather, to the target species, fishing places and according to the knowledge and abilities that each one possesses. In general, fishermen demonstrated to be "local experts", possessing an abundant knowledge of the environment that they use for both survival and sociocultural reproduction of their way of life. SWOT and DPSIR analyzes contributed to the systematization of the registered TK, allowing its use by managers and its application for local planning. It is recommended that both the TK and the participation of fishermen in decision-making practices should be considered in policies of management planning for coastal areas and natural resources.

Key-words: Araçá Bay; Integrated Coastal Management; Ethno-oceanography; Traditional ecological knowledge. 


\section{INTRODUÇÃO}

O sistema terrestre e seus diferentes ecossistemas sofrem mudanças constantes que ocorrem em diferentes escalas espaciais e temporais, em resposta a complexos processos de origem física, química e biológica (STEFFEN et al., 2005). Nos últimos dez mil anos, numa era dominada pela espécie humana - o "Antropoceno" (STEFFEN et al., 2005; MORAIS, 2008), ações de origem antropogênica têm influenciado cada vez mais os ecossistemas (PONTING, 1995; MORAN, 2008). Principalmente nas últimas décadas, pode-se dizer que os impactos gerados sobre a natureza não têm precedentes (MEA, 2005; MORAN, 2008, 2011) e, como resultado das alterações ambientais induzidas pelas civilizações, os recursos, as funções e os bens e serviços ecossistêmicos ${ }^{1}$ estão sendo depletados, o que afeta direta ou indiretamente o bem-estar humano (MEA, 2005).

A evolução das ciências, das tecnologias e dos meios e sistemas de produção possibilitou o desenvolvimento da humanidade, contudo, também contribuiu para o surgimento de desigualdades sociais e passivos ambientais (BELCHIOR, 2008). O elevado crescimento populacional, atrelado aos altos padrões de produção e hábitos de consumo das sociedades urbano-industriais modernas, especialmente nas nações desenvolvidas, são os principais fatores associados aos impactos e transformações que ocorreram no planeta nas últimas décadas (CICIN-SAIN, 1993; MORAN, 2008, 2011). Como consequências para os oceanos e zonas costeiras (ZCs), atualmente podemos considerar que não existem áreas marinhas intocadas, sendo as ZCs as regiões sobre maior pressão (HALPERN et al., 2008).

As ZCs são regiões extremamente dinâmicas, tanto na perspectiva de processos biofísicos (naturais) quanto socioeconômicos (antrópicos), localizadas na transição entre ambientes terrestres e marinhos (POST;

\footnotetext{
${ }^{1}$ Serviços ecossistêmicos são os benefícios provenientes dos ecossistemas em favor das necessidades humanas (MEA, 2005). Segundo a classificação da Avaliação Ecossistêmica do Milênio (MEA, 2005) esses serviços podem ser divididos em serviços de provisão (alimento, água, madeira, fibras, medicamentos, recursos genéticos etc.); serviços reguladores (ciclos hidrológicos, clima, doenças, resíduos etc.); serviços culturais (espirituais e religiosos, estéticos, educacionais, herança cultural etc.); e serviços estruturais (formação do solo, fotossíntese, polinização etc.). 
LUNDIN, 1996; CROSSLAND; BAIRD, 2005). Do ponto de vista biológico, são espaços capazes de suportar uma elevada produtividade primária e uma ampla variedade de ambientes como, por exemplo, praias, manguezais, restingas, marismas, costões rochosos e recifes de corais (CLARK, 1992; WESTMACOTT, 2001; MARTINS et al., 2012), que servem como habitat, e local de alimentação e proteção para inúmeras espécies de organismos (BIJLSMA et al., 1995; BURKE et al., 2001). Além dessa importância biológica/ecológica, as ZCs também têm uma grande relevância social e econômica (POST; LUNDIN, 1996; MARTíNEZ et al., 2007) e seus bens e serviços geram benefícios fundamentais para a vida humana (TURNER et al., 1998; BURKE et al., 2001; BEAUMONT et al., 2008).

Ao longo da história, as ZCs podem ser consideradas como as regiões mais favoráveis para 0 estabelecimento das populações humanas (RADCHENKO; ALEYEV, 2000), e, assim, tornaram-se áreas intensamente povoadas, que concentram cerca de dois terços da população mundial (MORAES, 2007). No Brasil, praticamente todos os ciclos econômicos estiveram ou estão relacionados ao território costeiro (POLETTE; LINS DE BARROS, 2012). Porém, a falta de planejamento nos processos de ocupação e urbanização desse território, tem gerado uma série de problemas ambientais e conflitos na disputa por espaços e recursos (AFONSO, 1998; TRAN et al., 2002; ERNANDORENA, 2003; MORAES, 2007; ABUCHAHLA, 2009; POLETTE; LINS DE BARROS, 2012).

$\mathrm{Na}$ atualidade, as ZCs são vistas como amplos espaços de interação setorial, institucional, demográfica e urbana na qual as relações entre o ser humano e o meio são afetadas pela dinâmica ambiental (MORAES, 2007; POLETTE; LINS DE BARROS, 2012). O crescente desenvolvimento de atividades como agricultura, aquicultura, pesca industrial, turismo, mineração, indústrias petrolíferas, transporte marítimo e portos, tem influência direta ou indireta sobre os ecossistemas costeiros e marinhos (CLARK, 1992; RADCHENKO; ALEYEV, 2000; WESTMACOTT, 2001; MORAES, 2007; TRENOUTH et al., 2012) e podem ocasionar impactos como: desmatamento da vegetação costeira (p.ex.: manguezais, restingas e marismas); intensificação de processos de erosão ou assoreamento da costa; poluição das 
águas e sedimentos; acidificação; depleção dos estoques pesqueiros; e perdas de habitats e de biodiversidade (CROSSLAND; BAIRD, 2005; CICIN-SAIN; BELFIORE, 2005, MARTINS et al., 2012). Tais impactos induzem mudanças sobre a vida marinha, habitats e paisagens (ATKINS et al., 2011) e, consequentemente, alteram a capacidade desses ambientes suportarem 0 "bem-estar" humano e fornecerem meios de subsistência, oportunidades de lazer e recreação, suporte à navegação e regulação climática (HALPERN et al., 2012).

Este cenário conflituoso e complexo, de gradativa degradação ambiental, é preocupante pois ameaça a própria manutenção dos diferentes modos de vida das populações humanas. Tal preocupação, aliada ao reconhecimento de que o planeta possui recursos finitos e de que a capacidade de absorção de impactos pelos ecossistemas é limitada, ganhou força principalmente a partir da década de 1970, influenciada pelas primeiras grandes iniciativas a nível global para tratar sobre a chamada "crise ambiental" (BUARQUE, 2008; XAVIER, 2010). Dentre essas iniciativas destacaram-se: 0 relatório do Clube de Roma ("Limites para o Crescimento"), de 1972 (MEADOWS et al., 1972); e a Conferência das Nações Unidas sobre o Meio Ambiente Humano (ou Conferência de Estocolmo), realizada em Estocolmo também em 1972 (UNEP, 1972). Em ambas, o grande tema em debate foi a necessidade de se pensar novas formas de desenvolvimento, que considerassem a capacidade de suporte dos ecossistemas, garantindo a conservação e preservação de recursos naturais através do uso racional e do manejo.

Outro marco importante, principalmente para a gestão dos oceanos e ZCs, foi a convenção das Nações Unidas sobre o Direito do Mar (CNUDM) realizada em 1982, que originou a Lei do Mar (MARTINEZ, 2012; WOR, 2015). Dentre outras definições importantes, a CNUDM estabeleceu critérios para delimitação dos limites jurisdicionais marinhos de responsabilidade das nações (que incluem o Mar Territorial e a Zona Econômica Exclusiva) e regras para controle da poluição dos oceanos visando a proteção e preservação dos ambientes marinhos (UN, 1982; WOR, 2015).

A evidente necessidade de assegurar o uso racional e a conservação 
dos espaços e recursos naturais costeiros e marinhos, levou a criação das primeiras iniciativas governamentais para a gestão das ZCs (CLARK, 1997; CICIN-SAIN; KNECHT, 1998). Ainda em 1972, mesmo ano da Conferência de Estocolmo, os EUA instituíram o primeiro plano de gestão das ZCs estabelecido por um governo, o Coastal Zone Management Act (POST; LUNDIN, 1996; CLARK, 1997; CICIN-SAIN; KNECHT, 1998; POLETTE; SILVA, 2003; XAVIER, 2010; MARTINEZ, 2012). Tais marcos reforçaram a necessidade de se repensar o modelo dominante, de valorização única e exclusiva do crescimento econômico, em detrimento de questões ambientais e, consequentemente, da própria qualidade de vida humana.

Nos anos seguintes, entre meados da década de 1970 e o início da década de 1980, outras nações seguiram os EUA e também passaram a desenvolver ações e esforços para a gestão da ZCs (SORENSEN, 1993; POST; LUNDIN, 1996; CICIN-SAIN; KNECHT, 1998). No entanto, essas primeiras iniciativas, possuíam um enfoque predominantemente setorial e priorizavam apenas porção terrestre do litoral (POST; LUNDIN, 1996; CLARK, 1997; CICIN-SAIN; KNECHT, 1998; POLETTE; SILVA, 2003). Posteriormente, percebeu-se abordagens centralizadas, setoriais e reducionistas, como 0 enfoque adotado por essas primeiras iniciativas, era insuficiente para lidar com os problemas enfrentados pelas ZCs e que esse ambiente era mais complexo do que se pensava (CICIN-SAIN; KNECHT, 1998; POLETTE; SILVA, 2003). Era necessário uma abordagem integrativa, capaz de reconhecer e lidar com a diversidade e complexidade dessas zonas de transição e interconexão "terramar", e dos processos socioecológicos que ali ocorrem.

Com a publicação do Relatório de Brundtland ("Nosso Futuro Comum"), em 1987 (CMMAD, 1991) e com a realização da Conferencia das Nações Unidas para o Meio Ambiente e Desenvolvimento (CNUMAD ou Eco 92), em 1992 no Rio de Janeiro (UNEP, 1992), o conceito de desenvolvimento sustentável ${ }^{2}$ foi formalmente adotado e passou a ser amplamente difundido na

\footnotetext{
2 Desenvolvimento sustentável é "o desenvolvimento capaz de suprir as necessidades da geração atual, sem comprometer a capacidade de atender as necessidades das gerações futuras de satisfazerem as suas próprias necessidades", ou seja, "significa possibilitar que as pessoas, agora e no futuro, atinjam um nível satisfatório de desenvolvimento social e econômico e de realização humana e cultural, fazendo, ao mesmo tempo, um uso razoável dos recursos da terra e preservando as espécies e os habitats naturais" (CMMAD, 1991).
} 
sociedade (BUARQUE, 2008). A CNUMAD reafirmou os compromissos estabelecidos na Conferência de Estocolmo (1972) e teve como alguns de seus principais resultados: a Convenção da Diversidade Biológica; a Declaração do Rio sobre o Meio Ambiente (Declaração do Rio); a Carta da Terra; e a Agenda 21, que teve um capítulo dedicado aos oceanos e costas intitulado "Capitulo 17 - Proteção dos oceanos, de todos os tipos de mares inclusive mares fechados e semifechados - e das zonas costeiras, e proteção, uso racional e desenvolvimento de seus recursos vivos" (UN, 1995).

O capítulo 17 da Agenda 21 foi fundamental para orientar as subsequentes propostas de gestão dos oceanos e ZCs (CICIN-SAIN et al., 1995) ao estabelecer "os direitos e as obrigações dos Estados" e oferecer "a base internacional sobre a qual devem se apoiar as atividades voltadas para a proteção e o desenvolvimento sustentável do meio ambiente marinho e costeiro, bem como seus recursos" (UN, 1995). Como o próprio documento destaca:

Isso exige novas abordagens de gerenciamento e desenvolvimento marinho e costeiro nos planos nacional, subregional, regional e mundial - abordagens integradas do ponto de vista do conteúdo e que ao mesmo tempo se caracterizem pela precaução e pela antecipação. (UN, 1995)

Após a CNUMAD, os princípios da integração e da sustentabilidade, e os princípios da prevenção e precaução, se tornaram norteadores das inciativas de gestão dos oceanos e ZCs ao redor do mundo e, assim, emergiu o conceito de Gerenciamento Costeiro Integrado - GCI (CLARK, 1992; CICINSAIN et al., 1995; CLARK, 1997; CICIN-SAIN; KNECHT, 1998; OLSEN, 2003; XAVIER, 2010; MARTINEZ, 2012).

\section{O GERENCIAMENTO COSTEIRO INTEGRADO (GCl)}

CICIN-SAIN e KNECHT (1998), definem o $\mathrm{GCl}$ como um processo contínuo e dinâmico através do qual são tomadas metas, decisões e ações para proteção, uso racional e desenvolvimento sustentável dos espaços e recursos naturais costeiros e marinhos. Para ASMUS et al. (2006), os principais objetivos do $\mathrm{GCl}$ são: (i) "preservar e proteger a produtividade e a biodiversidade dos ecossistemas"; (ii) "reforçar a gestão integrada"; e (iii) 
"promover o desenvolvimento racional e sustentável dos recursos".

Contudo, as ZCs são regiões altamente povoadas, abrigam grandes aglomerações urbanas, comportam uma ampla variedade de atividades humanas e, consequentemente, sofrem com diferentes pressões pelo uso de seus espaços e recursos (MORAES, 2007; XAVIER, 2010; POLETTE; LINS DE BARROS, 2012). Como exemplos, dentre as diversas questões que programas de $\mathrm{GCl}$ se propõe a abordar, pode-se citar: o combate a erosão costeira; o combate a poluição; o manejo da pesca e aquicultura; a regulação, controle e monitoramento de atividades como portos, indústria petrolífera e mineração; e a criação e o manejo de áreas naturais protegidas (CLARK, 1997; CICIN-SAIN; KNECHT, 1998). Assim, o grande desafio do GCl consiste em buscar um equilíbrio entre atividades potencias e demandas por espaços e recursos para, numa visão de curto, médio e longo prazo, promover a sustentabilidade da ZC (GESAMP, 1996; CLARK, 1997; CICIN-SAIN; KNECHT, 1998).

Considerando tais objetivos e desafios, entende-se que os processos de GCI devem ser flexíveis e capazes de lidar com a pluralidade e a complexidade das demandas e problemas existentes nas ZCs (CLARK, 1997). Tal perspectiva, requer uma abordagem holística, integrada e ecossistêmica, capaz de reconhecer os múltiplos fatores em interação, na formulação e implementação de políticas públicas (GESAMP, 1996; OLSEN, 2003; POLETTE; SILVA, 2003; ATKINS et al., 2011; SOUSA et al., 2013). Deste modo, abordagens capazes de considerar os diferentes interesses de ordem política, social, econômica, cultural e conservacionista, nos processos de compatibilização do uso e da ocupação das ZCs, de modo a promover uma maior interação entre a sociedade e o poder público e possibilitar uma participação mais efetiva do público alvo na tomada de decisão, são premissas fundamentais do GCI (GESAMP, 1996; EDWARDS et al., 1997; ELLSWORTH et al., 1997; POLETTE; SILVA, 2003; OLSEN, 2003; ABUCHAHLA, 2009; ATKINS et al., 2011; SOUSA et al., 2013).

Nesse contexto, e pautada nos princípios recomendados pela Agenda 21, XAVIER (2010) destacou quatro diferentes enfoques sobre os quais políticas no âmbito do $\mathrm{GCl}$ devem ser fundamentadas:

- Enfoque integrativo: integração intersetorial - entre os diferentes 
setores que influenciam e afetam as ZCs (sejam eles terrestres, costeiros e/ou marinhos); integração espacial - entre os diferentes ecossistemas costeiros (aquáticos e/ou terrestres) e entre as diferentes regiões político-administrativas; integração intergovernamental - entre os diferentes níveis de governo (local/municipal, estadual e federal); integração ciência-gestão entre diferentes disciplinas científicas e entre os próprios cientistas e os gestores e tomadores de decisão; e integração internacional - entre diferentes nações.

- Enfoque adaptativo: envolve o "auto-aprendizado" e o "aprender fazendo", no qual as lições e o conhecimento adquirido ao longo dos processos de gestão são incorporadas aos próprios processos visando sua adequação, melhoria e aperfeiçoamento.

- Enfoque ecossistêmico: adota o ecossistema como unidade de gestão sem separar as dimensões humanas (culturais, sociais e econômicas) e naturais (biofísicas).

- Enfoque participativo: visa garantir a democratização e a participação social nos processos de planejamento e gestão, aproximando o público alvo da tomada de decisão, sob a perspectiva do controle social.

Além de serem orientadas por tais enfoques, políticas de $\mathrm{GCl}$ devem ser constantemente avaliadas e, dentro das demandas e necessidades existentes, modificadas para se adequar a realidade e as questões que pretendem abordar (XAVIER, 2010). Neste sentido, a proposição de planos e programas de $\mathrm{GCl}$ pode ser pautada num modelo cíclico baseado em cinco etapas (Figura 1) que, no entanto, requerem feedbacks contínuos e podem sofrer alterações e adequações a qualquer momento do processo, visando seu aperfeiçoamento (GESAMP, 1996; OLSEN et al., 1999). Tais etapas são:

1. Identificação e análise das principais questões a serem consideradas (p.ex.: condições biofísicas/ambientais e estrutura político-institucional);

2. Preparação do programa ou plano de $\mathrm{GCl}$ a ser executado;

3. Adoção formal do programa e financiamento do mesmo; 
4. Implementação do programa;

5. E avaliação do programa, do processo e de seus resultados.

\section{Formas mais sustentáveis de gerenciamento costeiro}

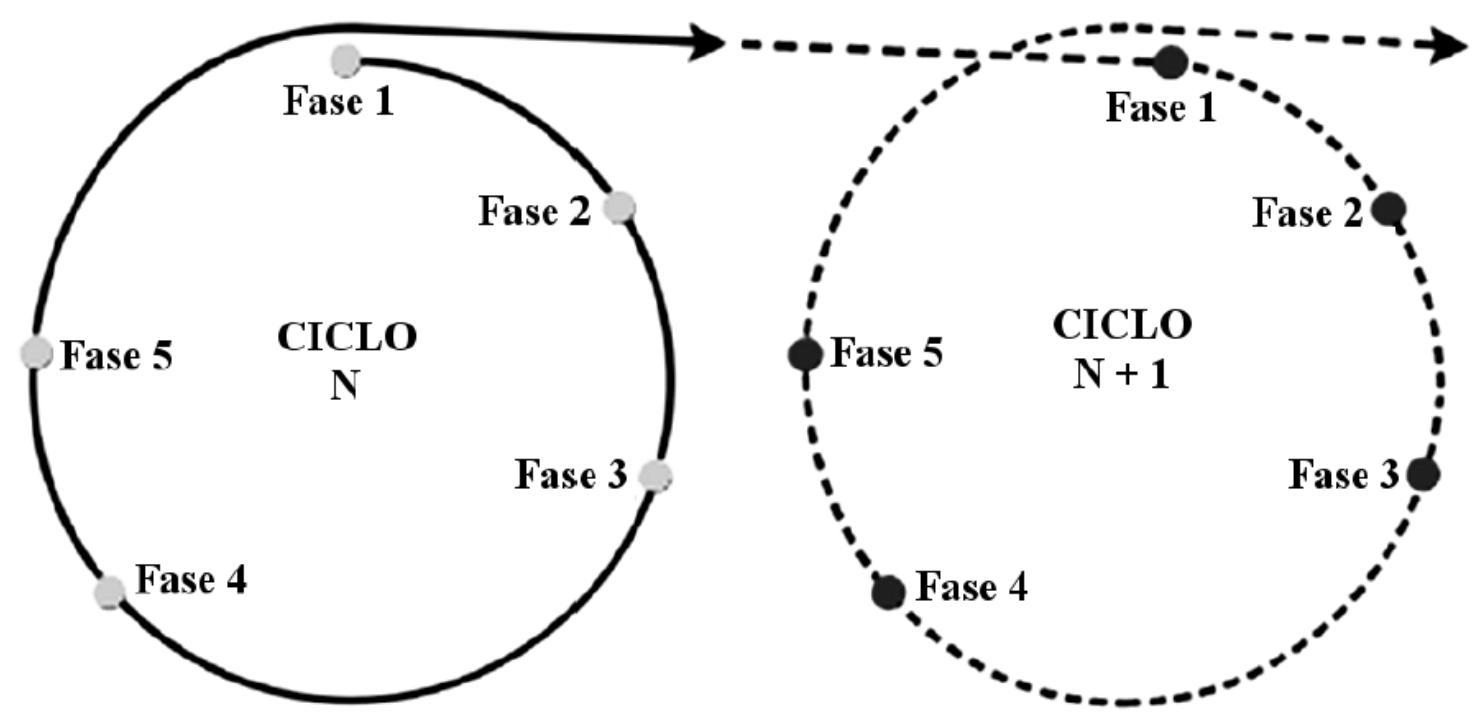

Figura 1: Etapas (1, 2, 3, 4 e 5) do processo de GCI, representadas em loopings (ciclos que se repetem). Fonte: XAVIER (2010) apud GESAMP (1996).

Atualmente há um consenso com relação aos princípios, objetivos e desafios do $\mathrm{GCl}$, e esse modelo tem sido amplamente aplicado ao redor do mundo, sendo adaptado às realidades e peculiaridades políticos-institucionais e socioambientais existentes em cada país (CICIN-SAIN; KNECHT, 2006). Desse modo, conforme destaca XAVIER (2010, p.7), no GCl "a forma como o processo é desencadeado e conduzido é diferenciada em cada caso". No caso brasileiro, esse processo se deu através de uma grande mobilização em nível nacional, que culminou na criação do Plano Nacional de Gerenciamento Costeiro, ou PNGC, em 1988 (MORAES, 2007; XAVIER, 2010).

\section{O GERENCIAMENTO COSTEIRO NO BRASIL E O PNGC}

A origem do PNGC (instituído pela Lei ํo7661/1988) está atrelada a outras políticas nacionais como a Política Nacional para os Recursos do Mar (aprovada por Decreto Presidencial em 1980) e a Política Nacional do Meio Ambiente (instituída pela Lei oㅜ6.938/1981), além de ser respaldado pela Constituição Federal de 1988, que conferiu a ZC brasileira o status de 
"Patrimônio Nacional" (MORAES, 2007). Pautado nessas políticas, o PNGC tem como principal objetivo, orientar o uso racional dos recursos costeiros e marinhos, contribuindo para a melhora da qualidade de vida e preservação do patrimônio natural histórico, étnico e cultural brasileiro (MORAES, 2007; XAVIER, 2010; MARTINEZ, 2012). Ao ter como finalidade primordial a promoção do ordenamento do uso dos recursos naturais e da ocupação desses espaços, assim como a identificação de potencialidades, vulnerabilidades e tendências existentes, o PNGC expressa um importante compromisso com a sustentabilidade da ZC brasileira (POLETTE; SILVA, 2003).

Após sua implementação e um processo de atualização que ocorreu durante a década de 1990, o PNGC foi revisado dando origem ao PNGC II, cuja regulamentação foi efetuada pelo Decreto 5.300/2004 (MORAES, 2007; XAVIER, 2010). Segundo afirma MORAES (2007, p.113), em relação a primeira versão:

A nova versão do PNGC reafirma o modelo institucional adotado anteriormente, que se estrutura seguindo os princípios da descentralização executiva e da ação cooperada entre os níveis de governo, porém acentuando a presença das esferas federal e municipal e da sociedade civil na condução do programa.

Outra atualização importante do PNGC II foi a do conceito de "zona costeira", que passou a ter um caráter menos acadêmico (técnico), e mais político-administrativo (MORAES, 2007). Na definição do PNGC II, a ZC brasileira foi limitada por uma "faixa terrestre", e por outra "faixa marítima": a primeira, correspondente aos municípios que sofrem influência direta dos fenômenos costeiros e marinhos, e, a segunda, correspondente a totalidade do mar territorial (espaço que se estende por 12 milhas náuticas a partir da linha de costa desses municípios). Esse enfoque geopolítico, utilizando os municípios e o mar territorial como critérios de definição dos limites da ZC, teve como objetivo facilitar a prática do planejamento e a aplicação dos instrumentos de gestão (MORAES, 2007).

Com a promulgação dos PNGC I e II, foram instituídas as normas gerais do gerenciamento costeiro no Brasil, e estabelecidas as definições e bases 9 
para a formulação de políticas e programas governamentais (MORAES, 2007; XAVIER, 2010; MARTINEZ, 2012). Além disso, também foram instituídos diversos instrumentos de gestão, dentre os quais: o Plano Estadual de Gerenciamento Costeiro - PEGC; o Plano Municipal de Gerenciamento Costeiro - PMGC; o Sistema de Informações do Gerenciamento Costeiro SIGERCO; o Sistema de Monitoramento Ambiental da Zona Costeira - SMAZC; o Relatório de Qualidade Ambiental da Zona Costeira - RQA-ZC; o Zoneamento Ecológico-Econômico Costeiro - ZEEC; e o Plano de Gestão da Zona Costeira - PGZN.

No processo de evolução do PNGC, os objetivos e princípios orientadores da gestão da ZC brasileira demonstram uma evidente intenção de encorajar a democratização, a descentralização, a participação pública e a integração (WEVER et al., 2012). Contudo, mesmo com os avanços realizados, o Estado tem permanecido como o grande indutor da ocupação do território e mediador das relações entre sociedade e espaço, e entre sociedade e natureza (MORAES, 2007). Somando-se a isso, conforme ressaltou COSTA (2005, p.55):

Na atualidade, as políticas públicas territoriais na escala nacional tendem a fragmentação, isto é, correspondem (e reiteram), de um lado, à crescente especialização dos aparelhos do Estado e à setorização dos planos, programas e projetos e, de outro, elas sucumbem no mais das vezes diante da variedade das demandas frequentemente conflitantes, geradas pelos novos e poderosos fluxos internacionais $e$ nacionais (de capitais, bens, serviços e informações).

Esse cenário tem resultado em conflitos e na falta de colaboração entre agências governamentais, bem como entre usuários que não compartilham das mesmas percepções e interesses (SERAVAL; ALVES, 2011; WEVER et al., 2012). Deste modo, a gestão dos espaços e recursos costeiros e marinhos, assim como a partição de benefícios, tem permanecido desigual (não equitativa), ameaçando a sustentabilidade da ZC brasileira (SERAVAL; ALVES, 2011; WEVER et al. 2012). 


\section{A PARTICIPAÇÃO DAS "COMUNIDADES" NA GESTÃO DOS ESPAÇOS E RECURSOS NATURAIS}

Desde a década de 1980, houve um reconhecimento das limitações dos Estados em ordenar e regular o uso dos espaços e recursos naturais (KNIGHT; MEFFE, 1997), principalmente daqueles considerados comuns ou de livre acesso, conforme os conceitos de regimes de propriedade estabelecidos por FEENY et al. (2001). Tais limitações estão atreladas ao fato de que muitos dos modelos de gestão convencionais eram pautados numa visão reducionista, cartesiana e disciplinar, em que a tomada de decisão era centralizada e efetivada através de políticas de comando e controle (MOURA, 2013). Contudo, atualmente, há um consenso de que novas abordagens são necessárias e, nesse contexto, a ideia de participação pública e compartilhamento de responsabilidades no planejamento e na tomada de decisão, é um tema que tem ganhado grande atenção e interesse de pesquisadores, profissionais, reguladores, gestores e governantes (PETERSON, 2011; ROWE et al., 2004).

$\mathrm{Na}$ literatura envolvendo a temática ambiental, existem diferentes estratégias de gestão pautadas na participação social (TABELA 1), que encorajam o envolvimento de cientistas, gestores, população local e outros atores sociais na gestão dos espaços e recursos naturais. No entanto, não há nenhuma maneira fácil de obtê-la, havendo a necessidade de acordos institucionais e mecanismos de governança eficazes. 
Tabela 1: Exemplos de estratégias de gestão dos espaços e recursos naturais, que levam em consideração a participação social e o compartilhamento de responsabilidades, no contexto da gestão integrada.

\begin{tabular}{|c|c|c|}
\hline Estratégias & Definição & $\begin{array}{l}\text { Referências da } \\
\text { literatura ambiental }\end{array}$ \\
\hline $\begin{array}{l}\text { "Manejo } \\
\text { comunitário" }\end{array}$ & $\begin{array}{l}\text { Tipo de gestão focada no papel das } \\
\text { comunidades locais que mantêm uma relação } \\
\text { de estreita dependência com os recursos } \\
\text { naturais. Prioriza a capacitação e a participação } \\
\text { das comunidades em relação à participação do } \\
\text { governo. }\end{array}$ & $\begin{array}{l}\text { Hildebrand,1997; } \\
\text { Hegarty, 1997; Rhoads et } \\
\text { al., 1999; Berkes, 2004; } \\
\text { Armitage 2005; Zagonari } \\
\text { 2008; Tissot et al., } 2009\end{array}$ \\
\hline $\begin{array}{l}\text { "Co-gestão } \\
\text { adaptativa" }\end{array}$ & $\begin{array}{l}\text { Combina as abordagens de co-gestão e gestão } \\
\text { adaptativa. Usa a ideia de compartilhamento do } \\
\text { poder e das responsabilidades entre os vários } \\
\text { grupos sociais através do caminho do "aprender } \\
\text { fazendo" (do inglês "learning by doing"). }\end{array}$ & $\begin{array}{l}\text { Berkes et al., 2000; } \\
\text { Carlsson e Berkes, 2005; } \\
\text { Schreiber e Bearlin, } \\
2004 \text {; Cumming et al. } \\
2006\end{array}$ \\
\hline $\begin{array}{l}\text { "Gestão } \\
\text { baseada em } \\
\text { ecossistemas" }\end{array}$ & $\begin{array}{l}\text { Uma abordagem integrada da gestão ambiental } \\
\text { que entende o sistema como um conjunto sócio- } \\
\text { ecológico, reconhecendo todas as interações } \\
\text { dentro de um ecossistema, incluindo aqueles } \\
\text { com seres humanos. Não priorizar as questões } \\
\text { individuais, espécie ou serviços do ecossistema } \\
\text { de forma isolada e não considera o homem e a } \\
\text { natureza como independentemente. }\end{array}$ & $\begin{array}{l}\text { Slocombe, 1998; Pikitch } \\
\text { et al., 2004; Arkema et } \\
\text { al., 2006; Barbier et al., } \\
\text { 2008; Tissot et al., 2009; } \\
\text { Curtin e } \\
\text { Prellezo, 2010; }\end{array}$ \\
\hline $\begin{array}{l}\text { "Governança } \\
\text { interativa e } \\
\text { adaptativa" }\end{array}$ & $\begin{array}{l}\text { Apesar de ser guiada por uma lógica de } \\
\text { governo, reconhece o papel das forças sociais } \\
\text { para auxiliar na gestão pública. Percebe a } \\
\text { importância da criação de novas estruturas } \\
\text { interativas para transformar os atores da } \\
\text { sociedade em colaboradores para a melhoria do } \\
\text { desempenho administrativo e da legitimidade } \\
\text { democrática. Vale ressaltar a dificuldade em se } \\
\text { estabelecer uma interação favorável para que } \\
\text { essas sinergias e colaborações possam surgir. }\end{array}$ & $\begin{array}{l}\text { Folke et al., 2005; Song } \\
\text { et al., 2013; Österblom et } \\
\text { al., } 2013\end{array}$ \\
\hline
\end{tabular}

Embora não exista uma única estratégia/modelo de gestão participativa/compartilhada, tal ideia pode ser entendida como um processo de construção de políticas públicas de forma conjunta, entre sociedade (incluindo os diversos atores sociais envolvidos) e Estado (governos, órgãos e agências governamentais) (ROWE; FREWER, 2000). Nesse contexto, principalmente na esfera local, destaca-se o papel das comunidades, cuja participação na discussão e elaboração de políticas pode fortalecer processos democráticos e o engajamento na defesa por interesses coletivos, contribuindo para o uso racional dos espaços e recursos (JACOBI, 2000; JACOBI; FRANCO 2011; STORI et al., no prelo).

Contudo, mesmo com o crescente interesse na utilização de abordagens 
participativas, a racionalidade "cognitivo-instrumental" tem prevalecido na elaboração de políticas ambientais (MORIN, 2004; SANTOS, 2007; JACOBI et al., 2015), pautada na ideia de que o conhecimento científico é o único capaz de ordenar o mundo de maneira confiável (ALLUT, 2000). No entanto, conforme ressaltou ALLUT (2000), existem outros saberes pautados em outras bases cognitivas, como o conhecimento tradicional (CT), que também são capazes de ordenar o mundo, prever fenômenos e atender as necessidades de sobrevivência das populações que os detém. Desse modo, o conhecimento tradicional pode ser atrelado ao conhecimento científico, contribuindo para o sucesso de modelos de gestão, pois leva em consideração as visões, opiniões, percepções e saberes dos próprios envolvidos na tomada de decisão (ALLUT, 2000; MOURA, 2009; 2013; HILL et al., 2010).

Nesse contexto, MCALLISTER (1999) destaca que novos enfoques de pesquisa têm surgido, fundamentados em "paradigmas antipositivistas e construtivistas", com o objetivo de promover uma a reflexão colaborativa entre gestores, reguladores, pesquisadores e comunidades locais, os quais:

(1) Reconhecem a existência, o valor e a legitimidade dos diferentes tipos de conhecimento, em particular 0 conhecimento "popular", "local" e "nativo"; (2) reconhecem que a informação e o conhecimento não estão livres de valores, e que a escolha seletiva da informação ou do conhecimento confere poder a alguns e tira o poder de outros; e (3) reconhecem que o conhecimento e a informação são construídos dentro de um contexto, que não existe uma (só) "explicação" ou "teoria" para um dado conjunto de fatos, e que a escolha da teoria depende de valores. (MCALLISTER, 1999, p.7)

Considerando essas premissas, diversos autores ressaltam a importância de pesquisas interdisciplinares direcionadas aos saberes das comunidades tradicionais (GADGIL et al., 1993; WEBLER et al., 1995; BERKES et al., 1995; 2000; MOURA, 2009; 2013), assim como às suas percepções e opiniões (GESAMP, 1996; JUNG et al., 2011; TAYLOR et al., 2011; PERES et al., 2016), para o desenvolvimento de políticas públicas no âmbito da gestão integrada. 


\section{POPULAÇÕES E TERRITÓRIOS TRADICIONAIS}

Existem inúmeros grupos de populações tradicionais ao redor do mundo, distintos em suas características socioculturais e territoriais, mas que possuem algumas similaridades, as quais merecem destaque: a intensa ligação com o território tradicionalmente ocupado; o conhecimento aprofundado da natureza; sistemas de produção e manejo voltados para subsistência; e a autoidentificação e identificação pelos outros enquanto um grupo distinto (DIEGUES, 2004a; 2008; DIEGUES; NOGARA, 1999). Baseada nessas premissas, a Política Nacional de Desenvolvimento Sustentável dos Povos e Comunidades Tradicionais (PNPCT), instituída no Brasil pelo Decreto 6.040/2007, define "Povos e Comunidades Tradicionais" como:

Grupos culturalmente diferenciados e que se reconhecem como tais, que possuem formas próprias de organização social, que ocupam e usam territórios e recursos naturais como condição para sua reprodução cultural, social, religiosa, ancestral e econômica, utilizando conhecimentos, inovações e práticas gerados e transmitidos pela tradição (BRASIL, 2007, art. 3ำ, inciso I).

Ao assumir tal definição, uma consideração importante é o fato de que as comunidades tradicionais possuem uma relação íntima com a natureza e dependem de seus recursos, tendo desenvolvido formas próprias de controle, exploração e manejo dos territórios nos/dos quais vivem (ADAMS, 2000a; BEGOSSI, 2000; DIEGUES, 2008). Nesses territórios, o manejo dos espaços e recursos é feito com base em mecanismos socioculturais próprios dessas comunidades, pautados em seus conhecimentos e práticas tradicionais que tendem a respeitar e levar em consideração os ciclos naturais e a capacidade de suporte do ambiente (BEGOSSI, 1998; DIEGUES, 2008). Deste modo, torna-se imprescindível entender o conceito de território, visto que esse é um elemento central do relacionamento entre as populações tradicionais e a natureza (DIEGUES, 2008).

Para GODELIER (1984), o território é uma porção da natureza e espaço em que uma sociedade reivindica e garante aos seus membros as condições e os meios materiais necessários para sua existência. Ou seja, é o espaço onde uma determinada população garante os direitos de acesso, uso e controle dos 
recursos naturais de que necessita (CASTRO, 2000). Assim, é no território que se constroem os meios de subsistência, trabalho e produção, além dos processos de reprodução social e cultural, essenciais para a sobrevivência dessas populações (DIEGUES, 2004a; 2008). Nesse sentido, o território transcende a ideia de espaço físico ocupado e, além de ser o "espaço de reprodução econômica e das relações sociais", é também "o locus das representações e do imaginário mitológico dessas sociedades" (DIEGUES, 2008, p.87).

Entretanto, tais espaços, seus recursos naturais e, consequentemente, o próprio modo de vida das populações que deles dependem, tem sido cada vez mais ameaçados pelo domínio das sociedades urbano-industriais (MORAN, 2008). São exemplos de fatores que tem ameaçado as populações tradicionais e sua manutenção em seus territórios: a ampla difusão de valores culturais atrelados ao consumo e a acumulação de capital (RUDDLE, 2000), o crescimento dos centros urbanos e da especulação imobiliária (ADAMS, 2000a; DIEGUES, 2004a), e o desenvolvimento de atividades econômicas como turismo de massa (DIEGUES, 2004a), pesca industrial (DIEGUES, 1983; 1993), agronegócio (MARQUES, 2001) e indústrias e portos (STORI et al., 2013). Além desses fatores, a perda de territórios tradicionais atrelado ao contexto de criação de áreas naturais protegidas (ANPs) pautadas num modelo restritivo e que não permite o uso direto dos espaços e recursos (mesmo que de forma sustentável), também é uma questão que tem sido foco de intenso debate (ADAMS, 1998; ARRUDA; 2000; PIMBERT; PRETTY, 2000; DIEGUES, 2000; 2008; VIANNA, 2008; CAPUCCI, 2016; GRABNER, 2016).

Nesse contexto, é necessário que políticas de gestão dos espaços e recursos naturais costeiro-marinhos visando sua conservação e sustentabilidade se aproximem das populações tradicionais que vivem nesses espaços, garantam sua manutenção nesses territórios e considerem suas opiniões, percepções, saberes, técnicas de manejo e sistemas de apropriação territorial (GADGIL et al., 1993; BERKES et al., 1995; RUDDLE, 1998; PIMBERT; PRETTY, 2000; DIEGUES, 2000; 2004b 2008; CORDELL, 2001; MEDEIROS, 2009; KALIKOSKI et al., 2009; MOURA, 2009; 2013; STORI, 2010). 


\section{O EXEMPLO DAS COMUNIDADES CAIÇARAS E SUA INSERÇÃO NO}

\section{"AMBIENTE" URBANO}

O termo caiçara tem origem no vocábulo tupi-guarani e era usado para denominar as estacas colocadas em volta das aldeias, ou o curral construído com galhos de árvores às margens de corpos d'água para cercar os peixes (ADAMS, 2000a). Atualmente, é usado para distinguir as comunidades tradicionais litorâneas originadas da miscigenação de índios, portugueses e negros (ADAMS, 2000a; DIEGUES, 2008; NETO, 2016) que habitam desde a costa sul do estado do Rio de Janeiro até a costa do estado do Paraná (DIEGUES, 2004a), região que inclui o Litoral Norte do Estado de São Paulo (LNSP), o município de São Sebastião e a Baía do Araçá.

Segundo MUSSOLINI (1980) e ADAMS (2000a, b), nessa região houve um período de relativo isolamento que perdurou desde o início do século XIX até meados do século XX. Tal condição propiciou a conformação de diversos núcleos comunitários ao longo das praias, baías e reentrâncias do litoral sudeste, isolados dos centros urbanos (em maior ou menor grau dependendo de sua posição geográfica) e afastados de influências culturais externas (MUSSOLINI, 1980; ADAMS, 2000a).

Cercados por um lado pela Mata Atlântica e por outro pelo oceano, as comunidades caiçaras consolidaram suas tradições, costumes e mecanismos próprios de uso e exploração dos recursos naturais locais, pautados num conjunto de saberes tradicionais sobre o mar e a mata (BEGOSSI, 1998; ADAMS, 2000a; DIEGUES, 2004a). Nesse cenário, os caiçaras desenvolveram como principais atividades produtivas a pesca artesanal e o cultivo de roças itinerantes (MUSSOLINI, 1980; DIEGUES, 1983, 2004a; BEGOSSI, 1998; ADAMS, 2000a, b; MOURÃO; NORDI, 2003; WILLEMS, 2003). Outra característica era fabricação e o uso de canoas de um pau só, utilizadas como principal meio de transporte marítimo entre as praias e cidades próximas, seja para a pesca ou seja para o transporte de pessoas e produtos (MUSSOLINI, 1980; MALDONADO, 2004; DENADAI et al., 2009).

Embora afastados e parcialmente isolados, de alguma forma, os caiçaras mantiveram algum contato com a cultura dos centros urbanos, da qual incorporaram diversos elementos (WILLEMS, 2003). No entanto, conforme 
destacou ADAMS (2000b, p. 151):

Após a abertura das estradas de acesso ao litoral norte do Estado de São Paulo, na segunda metade do século XX, as transformações socioeconômicas, que até então ocorriam lentamente, passaram a ocorrer de modo acelerado, com a chegada do turismo e da urbanização do litoral.

Para DIEGUES (2004a), principalmente após a metade do século XX, com o rápido desenvolvimento e urbanização das cidades do Litoral Norte de São Paulo, com a gradual perda dos espaços tradicionais terrestres e com a crescente inserção das comunidades no meio urbano-capitalista, muitos caiçaras deixaram de ser pescadores/lavradores e se tornaram pescadores artesanais urbanos. A pesca artesanal passou, então, a ser a principal atividade produtiva desses caiçaras, sendo praticada de forma combinada e alternada com outras atividades econômicas associadas a vida na cidade (DIEGUES, 2004a).

O modo de vida (caiçara), em muitos casos, altera-se profundamente, e nas cidades passa a se fundar na pesca, na coleta, atividades entremeadas com empregos urbanos, como pequeno comércio, construção civil... (DIEGUES, 2004a, p.42)

No processo de transição para a "vida urbana", até mesmo a pesca passou a ter uma menor importância em alguns locais e, ao invés de pescar e plantar, muitos caiçaras passaram a desempenhar trabalhos ligados ao setor de serviços, comércio, turismo, e construção civil (NOHARA, 2016). Ao considerar os diferentes processos de transformação e adaptação que as comunidades caiçaras sofreram, DIEGUES (2004a) desconstrói a ideia de que essa cultura é estática, homogênea e imutável. Desse modo, conforme observaram WILLEMS (2003) e DIEGUES (2004a), na cultura e no modo de vida caiçara a própria mudança pode ser vista como um "modelo de cultura".

\section{O CONHECIMENTO TRADICIONAL (CT) NA GESTÃO COSTEIRA}

Conforme exposto anteriormente, as comunidades tradicionais possuem um conjunto próprio de saberes a respeito dos seus territórios. Esse conhecimento tradicional (CT) é um conhecimento integrado, holístico e não fragmentado (quando comparado ao conhecimento gerado pela ciência 
positivista), que sumariza os mecanismos de adaptação dessas populações aos ambientes nos/dos quais vivem, tendo um importante potencial para auxiliar no desenvolvimento de estratégias de gestão local (GADGIL et al., 1993; BERKES et al., 1995; 2000; HILL et al., 2010; MOURA et al., 2013; NARCHI et al., 2014; RAMIRES et al., 2015). No caso das comunidades tradicionais que habitam as regiões costeiras, como os caiçaras do litoral paulista, seu CT pode combinar informações sobre espécies marinhas e seu comportamento, habitats costeiro-marinhos, processos físico-oceanográficos e métodos de manejo capazes de garantir sua subsistência (RUDDLE, 2000; DIEGUES, 2003, 2004a,b).

DIEGUES (2003, p.12) destaca três aspectos fundamentais atrelados ao CT:

- (1) o CT é cumulativo: produzido e reproduzido empiricamente através das gerações;

- (2) o CT é empírico: experimentado e testado diariamente;

- e (3) o CT é dinâmico: capaz de se transformar e de se adaptar em função de mudanças socioeconômicas, tecnológicas e físicas.

Quando colocado no contexto da conservação da biodiversidade e da sustentabilidade, existe uma série de razões práticas para o CT ser considerado em processos de gestão (BERKES et al., 1995). Segundo BERKES et al. (1995), o CT pode:

- oferecer novas perspectivas sobre características biológicas e ecológicas numa região;

- auxiliar o entendimento de processos que ainda não foram "decifrados" pelo conhecimento científico e/ou a formulação de novas hipóteses científicas;

- fornecer modelos para o manejo sustentável de recursos naturais e orientar o planejamento local;

- ser de grande relevância para áreas protegidas e para educação ambiental;

- ser usado no contexto de avaliações ambientais (BERKES et al., 1995). 
Especialmente em regiões onde há uma ausência ou carência de dados científicos, as percepções e o CT das comunidades locais tornam-se ainda mais relevantes (RUDDLE, 2000; DIEGUES, 2008; TAYLOR et al., 2011). Porém, é difícil interpretar o CT no âmbito da ciência normal positivista, o que demanda que ele seja sistematicamente investigado, organizado e avaliado, para que possa ser incorporado às políticas públicas (GADGIL et al., 1993 RUDDLE, 2000).

\section{A ABORDAGEM ETNOOCEANOGRÁFICA}

As etnociências (p.ex.: etnobiologia, etnoecologia, etnoicitiologia e etnobotânica) são abordagens particulares aplicadas a estudos interdisciplinares na interface entre as "ciências do homem" e da natureza (ROUÉ, 2000), que tem contribuído amplamente para o estudo das diferentes formas de CT (DIEGUES, 2000; 2008). Tal abordagem parte do pressuposto de que cada povo possui um sistema singular capaz de perceber, interpretar, organizar e classificar o mundo ao seu redor, atrelada a um contexto sociocultural, econômico e territorial (DIEGUES, 2000). O interesse dessas abordagens, ou campo de estudos, concentra-se no que LÉVI-STRAUSS (1973) denomina de "pensamento selvagem" ou "ciência do concreto", ou ainda, no que ROUÉ (2000) resume como sendo "a ciência de um povo".

Para CAMPOS (2002), as etnociências podem ser vistas como "uma etnografia de saberes do outro, construída a partir dos referenciais de saberes acadêmicos". O princípio fundamental por traz dessas ciências é entender a lógica subjacente ao conhecimento humano, percepções e interpretações do mundo natural e seus processos, através do uso da linguística (DIEGUES, 2008; MOURA; DIEGUES, 2009).

Uma distinção importante no âmbito das etnociências é a diferenciação entre as chamadas perspectivas êmica e ética. Na visão êmica, ou na visão "de dentro", procura-se compreender os sistemas de práticas e saberes tradicionais com base nos referenciais e nas categorias cognitivas e linguísticas da própria cultura estudada; já na visão ética, ou na visão "de fora", esse conjunto de saberes e práticas são analisados a partir do olhar e dos referenciais dos pesquisadores, ou seja, utilizando categorias cognitivas e 
linguísticas da ciência moderna (CAMPOS, 2002). Ambas são importantes mas podem ser difíceis de se distinguir no âmbito das etnociências, visto que a busca pela integração dessas perspectivas implica num compartilhamento de realidades entre indivíduos que pensam e se expressam de maneira distinta (POSEY, 2001).

A utilização de ambas as abordagens (êmica e ética) tem sido recorrente em pesquisas etnocientíficas, dentre as quais destaca-se um campo em especial: a etnoecologia. Numa definição pragmática a etnoecologia pode ser entendida como "o estudo científico do conhecimento ecológico tradicional" (MARQUES, 2001, p.49). Para MARQUES (2001), uma definição mais precisa desse conceito, que explicita melhor seu objeto de estudo e, ao mesmo tempo, é operacional, também pode ser apresentada como:

O campo de pesquisa (científica) transdisciplinar que estuda os pensamentos (conhecimentos e crenças), sentimentos e comportamentos que intermediam as interações entra as populações humanas que os possuem e os demais elementos dos ecossistemas que as incluem, bem com os impactos ambientais daí decorrentes. (MARQUES, 2001, p.16)

Considerando tal definição, MOURA (2013) refere-se a etnooceanografia como sendo uma perspectiva da etnoecologia que estende seu olhar sobre os ecossistemas marinhos (MOURA, 2013). Conforme destacou o autor:

A etnooceanografia coloca em perspectiva na etnoecologia as interações entre as populações e um determinado tipo de ambiência do ecossistema, os ecossistemas marinhos, estuarinos e/ou costeiros. Longe de representar a fundação de mais uma etnoárea, etno-coisas ou etno- $X$, a etnooceanografia se assume enquanto uma perspectiva possível da etnoecologia, a perspectiva etnooceanográfica. (MOURA, 2013, p.20)

Seguindo a proposta de MOURA (2009; 2013), o presente trabalho adota a perspectiva etnooceanográfica e se apoia nas premissas da etnoecologia propostas por MARQUES (2001), a saber:

(a) A aceitação de que a pesquisa etnoecológica pode ser feita em qualquer ecossistema (inclusive urbano) e em qualquer contexto sociocultural (inclusive o de letrados em 
sociedades industriais); (b) o reconhecimento da etnoecologia como um campo de cruzamento de saberes (no mínimo uma interdisciplina e não uma disciplina a mais); (c) a busca de uma integração entre a antropologia e biologia, porém indo além (quando possível bem além) disso; (d) a insistência em uma metodologia cientificamente enquadrável, mas que permita transgressões responsáveis (integrando subjetividade e objetividade) e heterodoxias assumidas (integrando razão e emoção); (e) o enfrentamento da quantificação necessária, porém enfatizando o tratamento qualitativo de realidades ocultáveis pela insuficiência da fala dos números. (MARQUES, 2001, p.15)

Assim, entende-se que a abordagem etnooceanográfica é voltada não só para a investigação do CT sobre aspectos biofísicos dos ambientes marinhos, mas também estende seu "olhar" para os aspectos humanos (socioculturais) das relações entre homem-natureza nesses ecossistemas. Trata-se de uma abordagem essencialmente interdisciplinar, que pode ser inserida no domínio da chamada Oceanografia Humana - "uma perspectiva que se funda em oposição às perspectivas clássicas, ao analisar a interligação e interdependência do ser humano com os oceanos e a Zona Costeira" (STORI et al., no prelo).

Tendo em vista a importância e o potencial de contribuição do CT em processos de gestão integrada, considera-se que a pesquisa etnooceanográfica pode colaborar diretamente para que o CT tenha seu devido reconhecimento e seja incorporado às políticas públicas, visando conservação e o uso sustentável dos ambientes e recursos naturais costeiro-marinhos. Neste contexto, uma aplicação do CT investigado por pesquisas etnooceanográficas (a qual será experimentada neste trabalho), é o aporte de informações a modelos conceituais (frameworks) que podem ser utilizados em processos de planejamento estratégico, para orientar a tomada de decisão no âmbito da gestão costeira integrada.

\section{MODELOS CONCEITUAIS (FRAMEWORKS) COMO SUPORTE A GESTÃO}

No contexto da gestão integrada e ecossistêmica dos espaços costeiros 
e marinhos, a aplicação de modelos conceituais (ou frameworks) tem sido amplamente utilizada (KELBLE et al., 2013). Esses modelos auxiliam no processo de integração e síntese das informações científicas (ou, no caso do presente trabalho, etnocientíficas) de uma forma prática para que gestores e tomadores de decisão possam incorporá-las às políticas públicas (ODGEN et al., 2005; SEKOVSKI et al., 2012). Tais ferramentas também podem, além de orientar o planejamento estratégico (SRIVASTAVA et al., 2005), melhorar a organização e comunicação das questões analisadas e, assim, seu entendimento, encurtando o tempo entre o processo de análise e a tomada de decisão (BRAUN; AMORIN, 2014).

Dentre os inúmeros frameworks existentes e utilizados atualmente, encontram-se os modelos "SWOT" (strengths, weaknesses, opportunities, threats/ forças, fraquezas, oportunidades e ameaças) e "DPSIR" (driving forces, pressures, states, impacts, responses/ fatores indutores de mudança ${ }^{3}$, pressões, estado, impactos, respostas). O primeiro (SWOT), volta-se para a análise de potencialidades e vulnerabilidades locais, considerando fatores internos e externos ao ambiente de interesse (PICKTON; WRIGHT, 1998; COWX et al., 2010; SRIVASTAVA et al., 2005); e o segundo (DPSIR), volta-se para a análise das relações entre causa e efeito envolvendo fatores antrópicos do cenário analisado e suas consequências socioambientais (SMEETS; WETERINGS, 1999; BOWEN; RILEY, 2003; LUNDBERG, 2005; GIUPPONI et al., 2006; TSCHERNING et al., 2012; GARI et al., 2015).

Sobretudo em áreas sujeitas a impactos e conflitos socioambientais, ambos promovem a reflexão em torno dos problemas, fragilidades e potencialidades evidenciados localmente, e podem ser utilizados em estágios preliminares de tomada de decisão, ou como ferramentas de planejamento estratégico (STORI et al., no prelo).

\section{A BAÍA dO ARAÇÁ (SÃO SEBASTIÃO-SP)}

A Baía do Araçá, ou apenas Araçá está localizada na borda continental do Canal de São Sebastião (CSS), ao lado do Porto de São Sebastião e nas

\footnotetext{
${ }^{3}$ A tradução direta do termo driving forces pode ser: "forçantes" ou "forças motrizes". No entanto, no modelo DPSIR o significado desse termo fica melhor traduzido como "fatores indutores de mudança", conforme apresentado nesse trabalho.
} 
proximidades da área central do município de São Sebastião, Litoral Norte do Estado de São Paulo, Brasil (Figura 2).

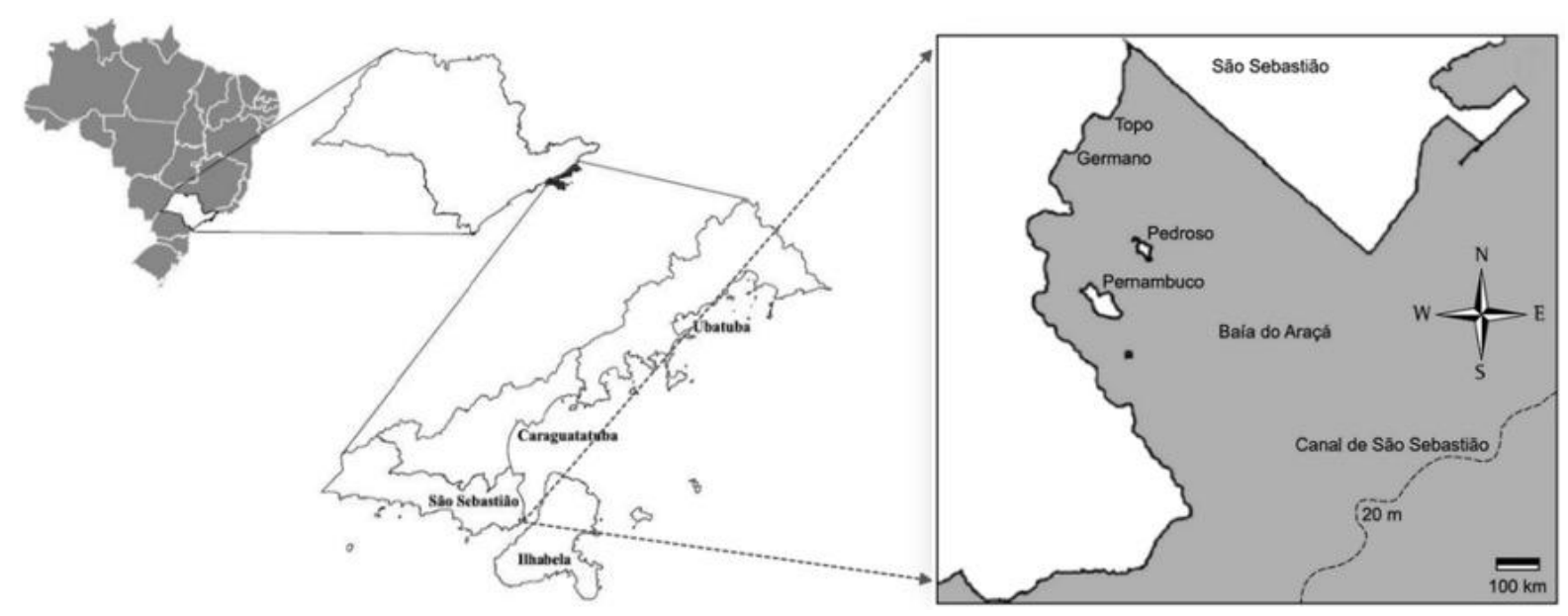

Figura 2: Localização da área de estudo. Em destaque: o Litoral Norte do Estado de São Paulo e a Baía do Araçá. Fonte: PERES et al. (2016).

Devido a sua geomorfologia e localização, é uma baía rasa e de baixa hidrodinâmica (dominada pela maré), protegida contra a ação direta de correntes e fluxos de água que ocorrem no CSS (AMARAL et al., 2010; AMARAL et al., 2015), que é mais profundo (com profundidades de até $45 \mathrm{~m}$ ) e sujeito a processos físicos-oceanográficos de maior intensidade (CASTRO et al., 2008). Em sua área interna há uma extensa planície de fundo arenosolamoso que, por sua baixa declividade, fica quase inteiramente descoberta durante a maré baixa de sizígia (AMARAL et al., 2010; 2015). Os limites laterais são promontórios rochosos e existem ainda duas ilhotas, quatro praias e três núcleos principais de bosques de mangue (AMARAL et al., 2010; 2015).

Quando comparado a outras baías costeiras, o Araçá compreende um espaço relativamente pequeno, com uma área interna de cerca de $550.000 \mathrm{~m}^{2}$ (ou aproximadamente $0,55 \mathrm{~km}^{2}$ - a título de comparação a Baía de Guanabara, Rio de Janeiro, possui cerca de $400 \mathrm{~km}^{2}$ ). Ainda assim, trata-se de um local que apresenta uma grande complexidade ambiental e que possui uma das maiores variedades de ambientes e diversidade do litoral brasileiro (AMARAL et al., 2010; 2015).

Essa ampla variedade de habitats, que inclui costões rochosos, praias, manguezais, uma ampla planície entremarés e uma área permanentemente submersa cuja profundidade aumenta gradativamente na medida em que avança na direção do CSS, comporta uma elevada produtividade e alta 
diversidade biológica (AMARAL et al., 2015). As características biofísicas do Araçá, aliadas à facilidade de acesso e à proximidade de centros de pesquisa, como o Centro de Biologia Marinha da Universidade de São Paulo (CEBIMar), fazem com que o local seja um verdadeiro laboratório natural para o desenvolvimento de atividades de pesquisas e ensino (AMARAL et al., 2015).

Até recentemente, embora a área do Araçá fosse utilizada constantemente para fins acadêmicos, os diversos trabalhos científicos produzidos possuíam caráter pontual, estando concentrados em áreas específicas do conhecimento como, por exemplo, estudos sobre a fauna marinha com foco na macrofauna bentônica (AMARAL et al., 2010). A primeira proposta com caráter interdisciplinar e integrador surgiu com a estruturação do Projeto "Biodiversidade e funcionamento de um ecossistema costeiro subtropical: subsídios para a gestão integrada", ou "Biota Araçá", financiado pela Fundação de Amparo a Pesquisa do Estado de São Paulo (FAPESP). Tal projeto, fruto do esforço conjunto de cerca de 170 pesquisadores, trata o Araçá como um estudo de caso da zona costeira, com objetivo de conhecer ampla e profundamente sua estrutura e seu funcionamento considerando processos físicos, biológicos, econômicos e sociais (AMARAL et al., 2015). Os resultados do Biota Araçá, no qual este trabalho se insere, estão sendo de grande importância para a proposição de políticas de gestão e para a tomada de decisão na Baía do Araçá (AMARAL et al., 2016).

O livro "A vida na Baía do Araçá" (de AMARAL et al., 2015) foi a primeira publicação integrada, com ênfase sobre a biodiversidade local, que sintetizou parte dos resultados do Projeto Biota Araçá. Conforme apresentado por AMARAL et al. (2015), 1364 espécies (táxons) foram identificadas no local, das quais mais de 50 são novas para a ciência. Isso inclui centenas de espécies de macroalgas, fitoplâncton, zooplâncton e invertebrados bentônicos, 122 espécies de peixes, 60 epécies de aves e uma de tartaruga, "que utilizam a baía em busca de um lugar seguro para se reproduzir, crescer e se alimentar" (AMARAL et al., 2015, p.29). Além de ser uma região de grande importância ecológica, considerada um laboratório a céu aberto, o Araçá também é um local onde há a presença frequente de usuários que dependem de seus serviços e recursos ambientais, como pescadores artesanais e catadores de 
mariscos e siris, cujo produto é comercializado ou utilizado para o consumo próprio (AMARAL et al., 2010; 2015; CARRILHO, 2015; PERES et al., 2016).

Atualmente, o Araçá é parte de duas ANPs consideradas de uso sustentável (uso direto), a Área de Proteção Ambiental Marinha Municipal de Alcatrazes (criada pela lei municipal 848/1992) e a Área de Proteção Ambiental Marinha do Litoral Norte (APAMLN - estabelecida pelo Decreto Estadual ํo53.525/2008). Conforme estabelecido pelo Sistema Nacional de Unidades de Conservação (SNUC - Lei no 9.985/2000), tais categorias de ANPs permitem a utilização dos espaços e recursos naturais pela população residente, desde que assegurada sua conservação e sustentabilidade (VIANNA, 2008).

Entretanto, há muitos anos o ambiente local vem sendo exposto a diferentes tipos de ação antrópica, tais como: ocupações irregulares; turismo sazonal; lançamento de efluentes de esgoto doméstico; além da proximidade do centro urbano do município, do Porto de São Sebastião e do Terminal Marítimo Almirante Barroso - TEBAR (Figura 3), onde ocorrem constantes acidentes envolvendo derrames de óleo e outras perturbações (AMARAL et al., 2010; TURRA et al., 2015; PERES et al., 2016). 


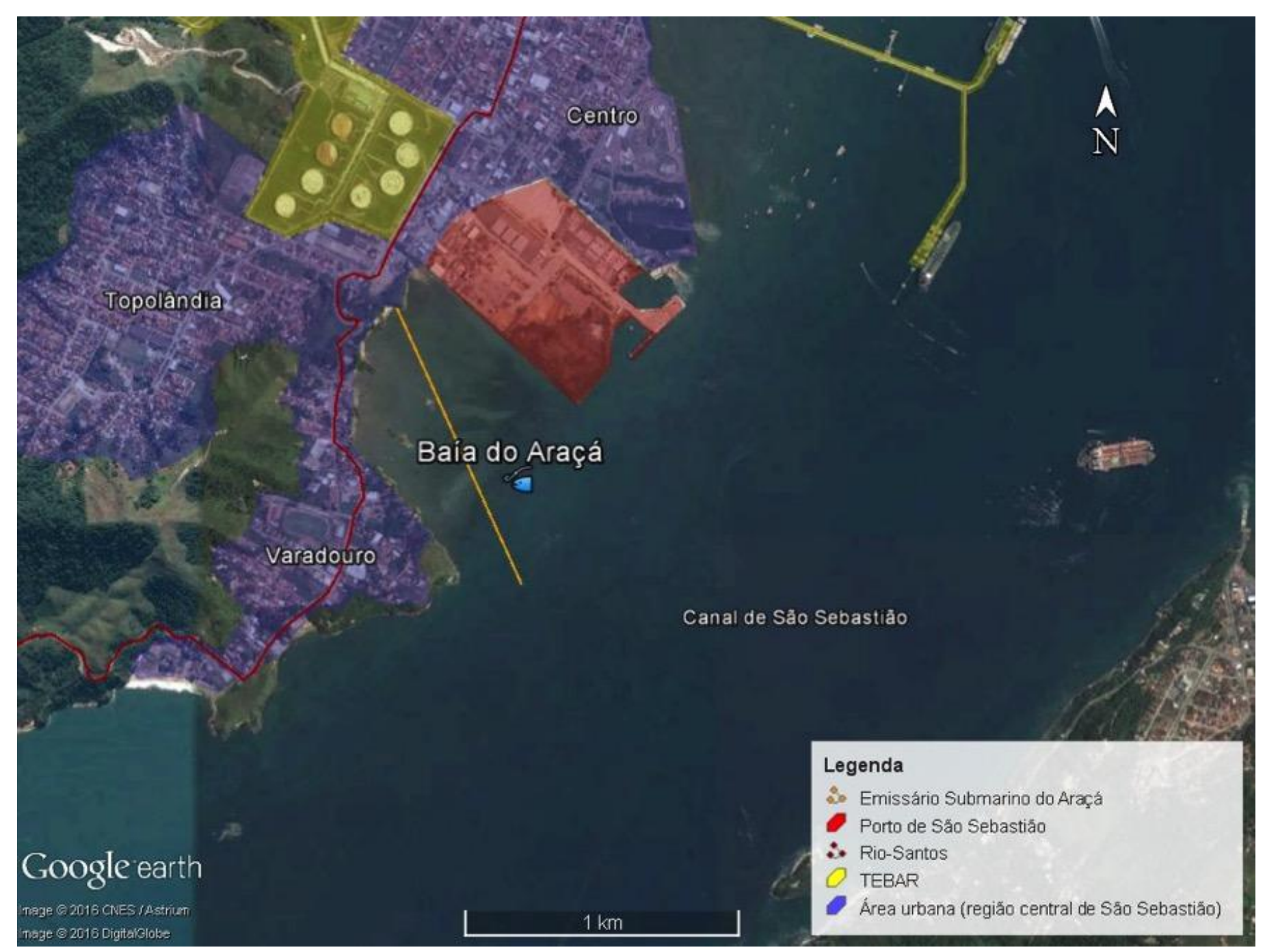

Figura 3: Região da Baía do Araçá e seu entorno urbanizado, com destaque para o Porto de São Sebastião, TEBAR, Rodovia Rio-Santos (SP-055) e para o Emissário Submarino do Araçá. 


\section{Histórico de ocupação e de transformações do Araçá}

O início da ocupação da área central do município de São Sebastião, adjacente à Baía do Araçá, ocorreu no período colonial em meados do século XVI (RESSURREIÇÃO, 2002). Porém, o histórico de transformações mais significativas sobre o local teve início apenas a partir do século XX. A primeira grande mudança foi a construção do Porto de São Sebastião entre 1936 e 1954 (ALBUQUERQUE, 2013). A construção do cais do porto dividiu a orla sebastianense e formou a Baía do Araçá (Figura 4), separando essa região da praia que existia em frente ao centro histórico da cidade (PERES et al., 2016).

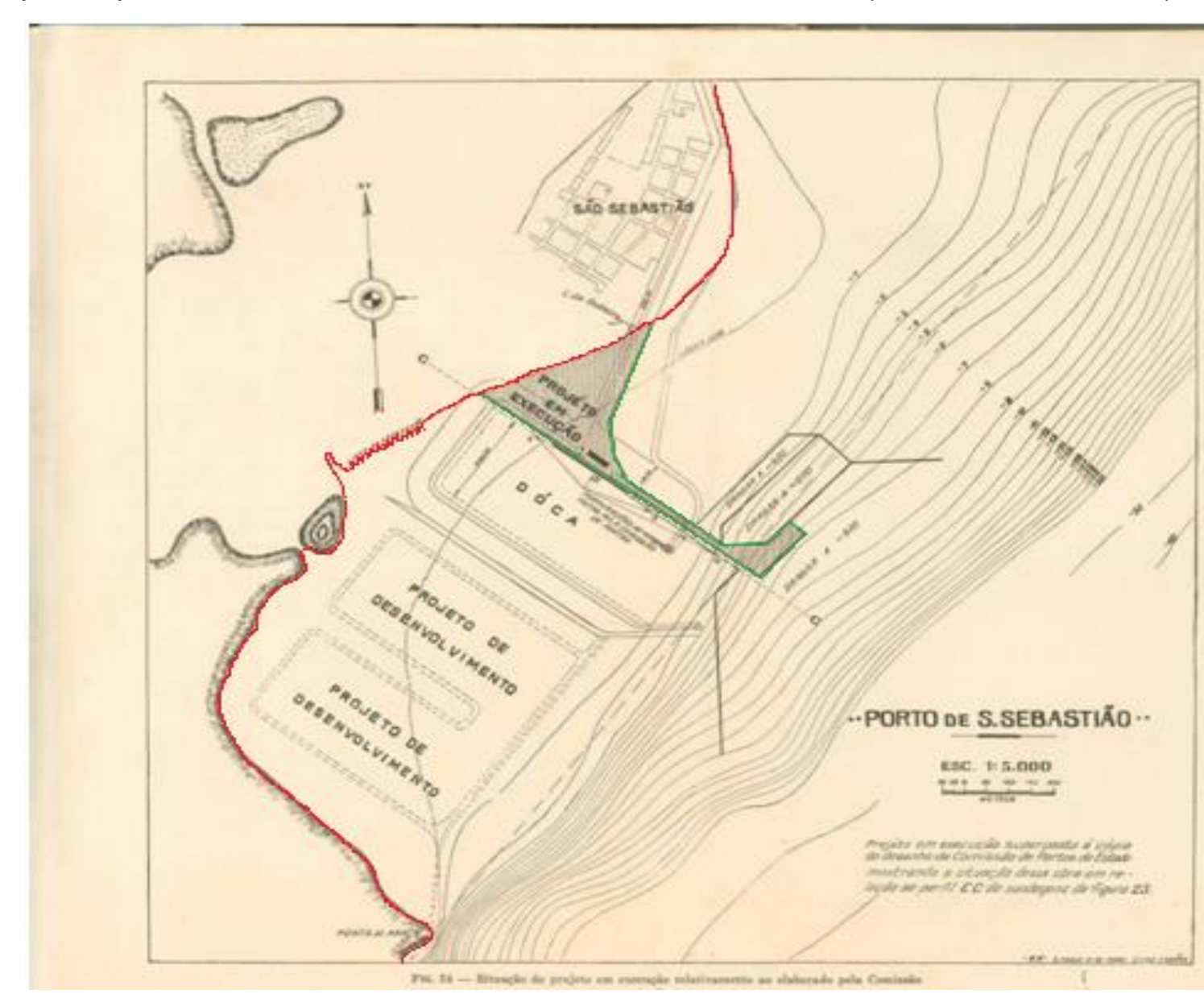

Figura 4: Projeto de construção do cais do Porto de São Sebastião executado durante a década de 1940, com destaque para a linha de costa original (em vermelho) e para o cais do porto (em verde). Fonte: Companhia Docas de São Sebastião (2011)

Apesar da construção do porto, houve poucas mudanças no entorno do Araçá nos anos que se seguiram. Nesta época, poucas famílias residiam ao longo das bordas da baía e o local era utilizado apenas para coleta e pesca (artesanal) de organismos marinhos como fonte de subsistência, ou para o embarque e desembarque de pessoas e produtos em canoas de voga 
(RESSURREIÇÃO, 2002).

Contudo, esta realidade "pacata" começou mudar principalmente a partir da década de 1950, quando outras grandes obras foram realizadas e novos empreendimentos surgiram na região (PERES et al., 2016). Dentre essas obras e empreendimentos destacam-se:

- A ampliação do Porto de São Sebastião que ocorreu em duas etapas (a primeira no início da década de 1970 e a segunda no final da década de 1980) e deu origem ao aterro de parte da baía e extinguiu a antiga "Praia do Areião";

- A chegada da Petrobrás (na década de 1960), e a construção de seu terminal petrolífero (Terminal Marítimo Almirante Barroso TEBAR), entre as décadas de 1970 e 1980, cujas obras levaram ao aterro da antiga "Praia da Frente" (localizada em frente ao centro histórico do município);

- O asfaltamento das rodovias SP-099 (Rod. dos Tamoios) e SP055 (Rod. Rio-Santos) na década de 1980 - tais rodovias facilitaram o acesso a região, que até então só era possível por estradas de terra; $\mathrm{e}$

- A construção do Emissário Submarino do Araçá em 1990.

A presença do porto, da Petrobrás e de rodovias de acesso asfaltadas (que impulsionaram o desenvolvimento do turismo na região), levaram a um rápido crescimento populacional e urbano no município (principalmente entre os anos de 1980 e 2000), marcando uma nova fase de desenvolvimento em São Sebastião (CUNHA, 2003; PAES, 2006). De 1980 a 2010, a população da cidade que era de 18.839 habitantes aumentou mais de três vezes chegando a 73.942 habitantes (SEADE, 2013). Esse crescimento se deu de forma desordenada e levou ao desmatamento de áreas vegetadas, descargas de efluentes não tratados, ocupação de áreas irregulares, e desalojamento de famílias caiçaras de seus locais de origem (CARVALHO, 2001; CUNHA, 2003).

No Araçá não foi diferente e seu entorno também seguiu essa tendência. Houve um rápido crescimento urbano ao redor da baía, onde atualmente moram centenas de pessoas e existem diversos estabelecimentos comerciais e empresas. Tais transformações foram percebidas por moradores 
antigos da região que observaram, dentre outros impactos, o aumento da poluição no local com lixo, entulho e esgoto chegando à suas águas (PERES et al., 2016).

Desde 2010, novos debates tem ganhado força em torno de projetos e grandes obras previstas para a região, com as propostas de ampliação da Rodovia dos Tamoios, do píer do TEBAR e, principalmente, do Porto de São Sebastião. O projeto de ampliação portuária, intitulado Plano Integrado PortoCidade (PIPC), apresentado audiência pública em 2011 pela Companhia Dersa de São Sebastião (responsável pela administração do porto atualmente), previa a ocupação de $75 \%$ da área da Baía do Araçá, e a inserção de 17.067 pilotis (estacas) para a construção de estruturas portuárias suspensas, como terminais e pátios (Figura 5). Tal proposta gerou várias manifestações contrárias de moradores da região, de moradores do município vizinho, Ilhabela, e da comunidade científica que tem desenvolvido projetos de pesquisa na área. Em 2013, após uma modificação da proposta inicial (sem que houvesse uma ampla discussão com a comunidade local), o lbama emitiu a licença prévia autorizando o início da ampliação do porto, contudo tal licença foi suspensa em 2014 e anulada em abril de 2016.

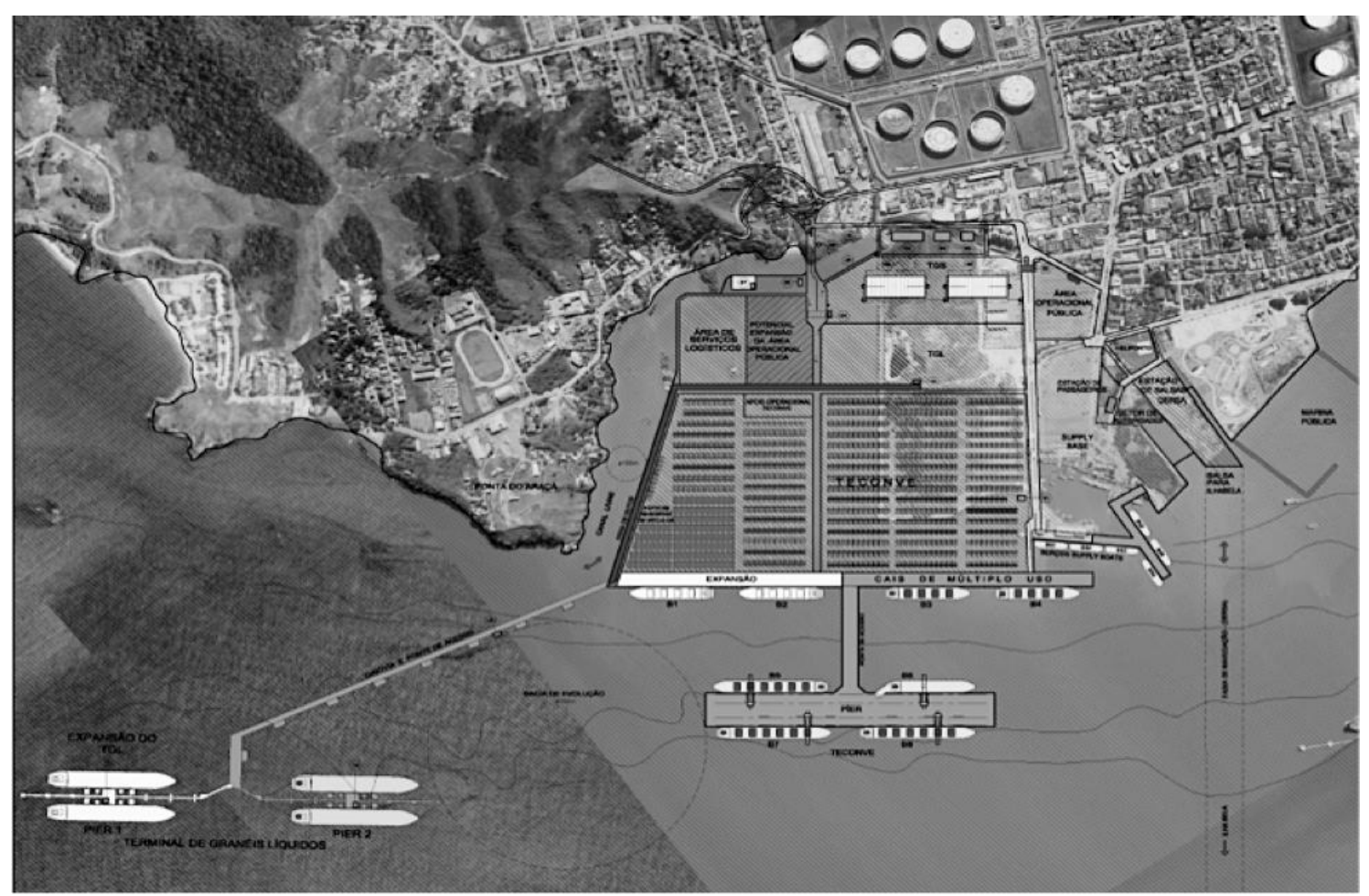

Figura 5: Proposta de ampliação do Porto de São Sebastião apresentada pela Companhia Docas de São Sebastião, em 2011. Fonte: Companhia Docas de São Sebastião (2011). 
Embora o Araçá seja uma área castigada, que ainda sofre e é ameaçada, moradores antigos que praticam a pesca e a "catação" no local, consideram que esta se recuperou e está se recuperando das intervenções pelas quais passou (PERES et al., 2016). Conforme evidenciam os resultados do Projeto Biota Araçá, a baía permanece viva, rica e diversa, fornecendo bens e serviços fundamentais para vida humana (CARRILHO, 2015; AMARAL et al., 2015; 2016). Todavia, para que essa realidade não se deteriore e que as gerações futuras não sejam comprometidas, são necessários esforços para uma gestão local integrada capaz de conciliar usos, equacionar conflitos e lidar com toda essa complexidade que envolve fatores ambientais, socioculturais e econômicos.

Assim como em diversas localidades da costa brasileira e de outros países, a região da Baía do Araçá vem sofrendo diversas alterações, pressionada por grandes empreendimentos (PERES et al., 2016) relacionados ao desenvolvimento econômico regional (SANTOS; TURRA, no prelo). Hoje, seu estado e dinâmica é reflexo de conflitos e impactos que comumente afligem e influenciam a qualidade das regiões costeiras ao redor do mundo (SANTOS; TURRA, no prelo). Tais impactos não só afetam aspectos naturais como também alteram a relação das pessoas com o meio ambiente ali existente, implicando em mudanças socioambientais. No caso do Araçá, além das consequências negativas à sua rica biodiversidade e serviços ecossistêmicos, parte das relações potencialmente afetadas por esse cenário conflituoso são as relações estabelecidas pelos pescadores artesanais da região, através da cultura caiçara. Dessa forma, esse complexo e inusitado cenário, permite o uso dessa região para analisar e agregar novos elementos à temática da etnooceanografia aplicada à gestão, como proposto no presente trabalho. Espera-se, com isso, contribuir para um melhor uso dos espaços e recursos naturais da costa brasileira. 


\section{HIPÓTESES E OBJETIVOS}

Considerando os referenciais teóricos e o contexto de pesquisa apresentados, as hipóteses e objetivos que nortearam essa pesquisa foram:

I. Há pescadores artesanais (caiçaras) que utilizam a região da Baía do Araçá como território tradicional de pesca;

- Objetivo 1: caracterizar os pescadores artesanais tradicionais (caiçaras) da Baía do Araçá e as principais características da pesca artesanal nessa região;

II. Esses pescadores possuem um amplo conjunto de saberes (CT) sobre o funcionamento do ambiente local e sobre como esse funcionamento pode afetar/influenciar a pesca;

- Objetivo 2: identificar o CT dos pescadores artesanais da Baía do Araçá sobre aspectos biofísicos desse ambiente costeiro e sua influência na pesca;

III. O CT desses pescadores pode aportar informações para processos de planejamento e gestão dos espaços e recursos costeiro-marinhos na região.

- Objetivo 3: investigar o CT dos pescadores sobre a situação atual do ambiente local (importâncias e problemas), bem como suas opiniões e perspectivas sobre o futuro da região; e

- Objetivo 4: com base no conjunto de informações obtidas sobre o CT dos pescadores, aplicar os modelos SWOT e DPSIR, para subsidiar a proposição de estratégias de gestão local. 


\section{MÉTODOS}

Para atingir os objetivos norteadores desta pesquisa, seguiu-se uma abordagem etnooceanográfica de caráter êmico/ético. Sob a perspectiva êmica (POSEY, 1987; 2001, MARQUES, 2001; MOURA 2013), buscou-se investigar conceitos, processos e classificações de aspectos biofísicos do ambiente local, segundo a ótica dos nativos que, nesse caso, são os pescadores artesanais caiçaras da Baía do Araçá. Do ponto de vista ético (POSEY, 2001; MARQUES, 2001; MOURA 2013), não se pode excluir o fato de que muitos dos temas debatidos com os nativos foram pré-definidos a partir de teorias, hipóteses e do conhecimento científico prévio, e que parte das informações registradas foram analisadas e interpretadas sob uma ótica não nativa (externa).

Tendo em vista essa relação êmica/ética, o conjunto de métodos que foram utilizados neste trabalho foi dividido seguindo as seguintes etapas:

- Seleção e identificação dos "atores-alvo" da pesquisa (objetivo 1);

- Coleta e registro das informações de interesse (objetivos 1, 2 e 3);

- Organização e análise das informações obtidas (objetivos 1, 2 e 3); e

- Aplicação de modelos de planejamento o SWOT e o DPSIR (objetivo 4).

\section{Métodos de seleção e identificação dos atores-alvo}

Para seleção dos atores que compõe o público-alvo desta pesquisa, utilizou-se apenas um único requisito/critério: que esses atores fossem pescadores artesanais que utilizam a região da Baía do Araçá como território pesqueiro, possuindo assim identificação com o local e um amplo conhecimento empírico sobre o mesmo. Deste modo, a identificação de atores que se enquadrassem nesse critério foi iniciada por meio de visitas de reconhecimento e aproximação com a comunidade (STORI, 2010) que ocorreram no início de 2014. Nessas visitas à baía, foi possível estabelecer um primeiro contato e conversas iniciais com alguns desses atores-alvo (STORI, 2010), ao encontrá-los nas praias e áreas rasas da baía coletando berbigão e siris, ou voltando com suas canoas após deixar ou buscar uma rede.

Após a identificação e o contato inicial com os primeiros pescadores 
artesanais da Baía do Araçá, seguiu-se o método conhecido como "bola de neve" (WRIGHT \& STEIN, 2005), no qual as primeiras pessoas entrevistadas indicam outras que se enquadram no perfil da pesquisa, até que as indicações passem a ser repetidas e que não seja possível identificar novos atores. Ao todo, cerca de 30 pessoas foram identificadas através das visitas de reconhecimento e indicações, mas nem todos puderam ser contatados ou se disponibilizaram a participar da pesquisa. Por fim, 18 pessoas que se enquadravam no perfil pré-estabelecido aceitaram participar da pesquisa e responderam as entrevistas (etapa de aquisição e registro de informações).

É importante ressaltar que durante todos os momentos de interação entre o "pesquisador" e os "atores-alvo", a ética do respeito foi tomada como premissa fundamental, seguindo as recomendações de POSEY (1987), MARQUES (2001) e MOURA (2013). Conforme afirma MOURA (2013), a ética do respeito é indispensável para se manter a horizontalidade nas relações com o público-alvo da pesquisa e, assim, estabelecer um relacionamento entre iguais.

\section{Métodos de aquisição e registro das informações}

A coleta das informações de interesse dessa pesquisa foi realizada por meio de entrevistas semiestruturadas (VIERTLER, 2002; BUARQUE, 2008) e da composição de mapas falados (FARIA; NETO, 2006; BUARQUE, 2008) com os atores-alvo. Tais métodos foram aplicados durante 5 visitas de campo que foram realizadas na região da Baía do Araçá entre outubro de 2014 e março de 2015. Além de servir para realização dos registros das entrevistas e dos mapas, essas visitas de campo também serviram para obervar e fotografar características da região e do modo de vida desses pescadores (STORI, 2010).

A realização de entrevistas pode ser considerada a técnica mais utilizada em trabalhos de campo na coleta de dados sobre um determinado tema, principalmente no âmbito das pesquisas sociais (GIL, 1989). Definida como um processo de interação entre duas pessoas, o entrevistador (pesquisador) e o entrevistado (informante), as entrevistas tem como principal intuito obter informações de interesse para a investigação realizada (GIL, 1989; VIERTLER, 2002; BUARQUE, 2008). Assim, a averiguação de fatos, opiniões e condutas acerca de um determinado assunto estão entre os principais 
objetivos para realização de entrevistas (MARCONI; LAKATOS, 2003). A utilização desta técnica, no entanto, apresenta limitações como a possibilidade de dúvidas na interpretação dos significados das perguntas (GIL, 1989). Porém, tais limitações são fáceis de se contornar por se tratar de uma técnica que oferece flexibilidade e adaptação (GIL, 1989).

Ao todo, 18 entrevistas foram realizadas (uma com cada pescador que aceitou participar da pesquisa) e todas foram guiadas por um mesmo questionário semiestruturado (ANEXO 1). Este questionário, desenvolvido seguindo os objetivos da pesquisa, foi composto, predominantemente, por perguntas abertas (cujo foco principal foi obter informações sobre a Baía do Araçá com base no CT dos pescadores locais) mas contendo, também, perguntas fechadas (usadas para aquisição de dados socioeconômicos sobre os entrevistados). Cada entrevista perdurou por um período médio de 2 horas, e o registro das falas foi realizado, simultaneamente, por um gravador digital (responsável por gravar cada entrevista na íntegra) e por anotações feitas a mão em uma versão impressa do questionário.

Vale lembrar que, antes do início de cada entrevista, os objetivos e propósitos da pesquisa foram informados aos participantes, juntamente com a leitura de um termo de consentimento (ANEXO 2). Em seguida, cada entrevistado autorizou a realização e o registro da entrevista, e assinou esse termo de consentimento. Apenas após a permissão de cada participante é que se deu início as entrevistas, que foram realizadas na forma de conversa permitindo uma maior flexibilidade e liberdade para discorrer sobre os temas abordados (BONI; QUARESMA, 2005).

Durante as entrevistas, além de responder as perguntas, foi pedido a cada participante que também compusesse seu próprio mapa falado. O mapa falado consiste em um desenho de características do espaço ou território sob reflexão (FARIA; NETO, 2006; BUARQUE, 2008) que, neste caso, trata-se da região da Baía do Araçá. Tal método possibilita uma visão espacial do local e de seus principais aspectos, auxiliando a obtenção de informações exploratórias e contribuindo para construção de uma visão geral sobre a realidade local (FARIA; NETO, 2006).

O mapa de cada pescador foi desenhado sobre uma planta-base da 
Baía do Araçá contendo apenas a linha de costa como referência (Anexo 3), que foi impressa em papel A3. Nesse mapa, utilizando como ferramentas gizes de cera coloridos (Figura 6), pediu-se aos pescadores que representassem, segundo sua própria perspectiva, características locais como, por exemplo:

- Áreas importantes para a produção de pescado;

- Áreas que poderiam ser "fechadas" para a pesca (áreas de restrição a atividade pesqueira);

- Áreas de pesca e coleta ("catação");

- Áreas preferenciais de ocorrência das principais espécies capturadas;

- Sentido de fluxo/deslocamento das águas (correntes costeiras); e

- Locais de guarda das embarcações.

Assim, cada mapa constituiu numa importante fonte de informações sobre o ambiente local, de modo complementar ao conteúdo registrado nas entrevistas.

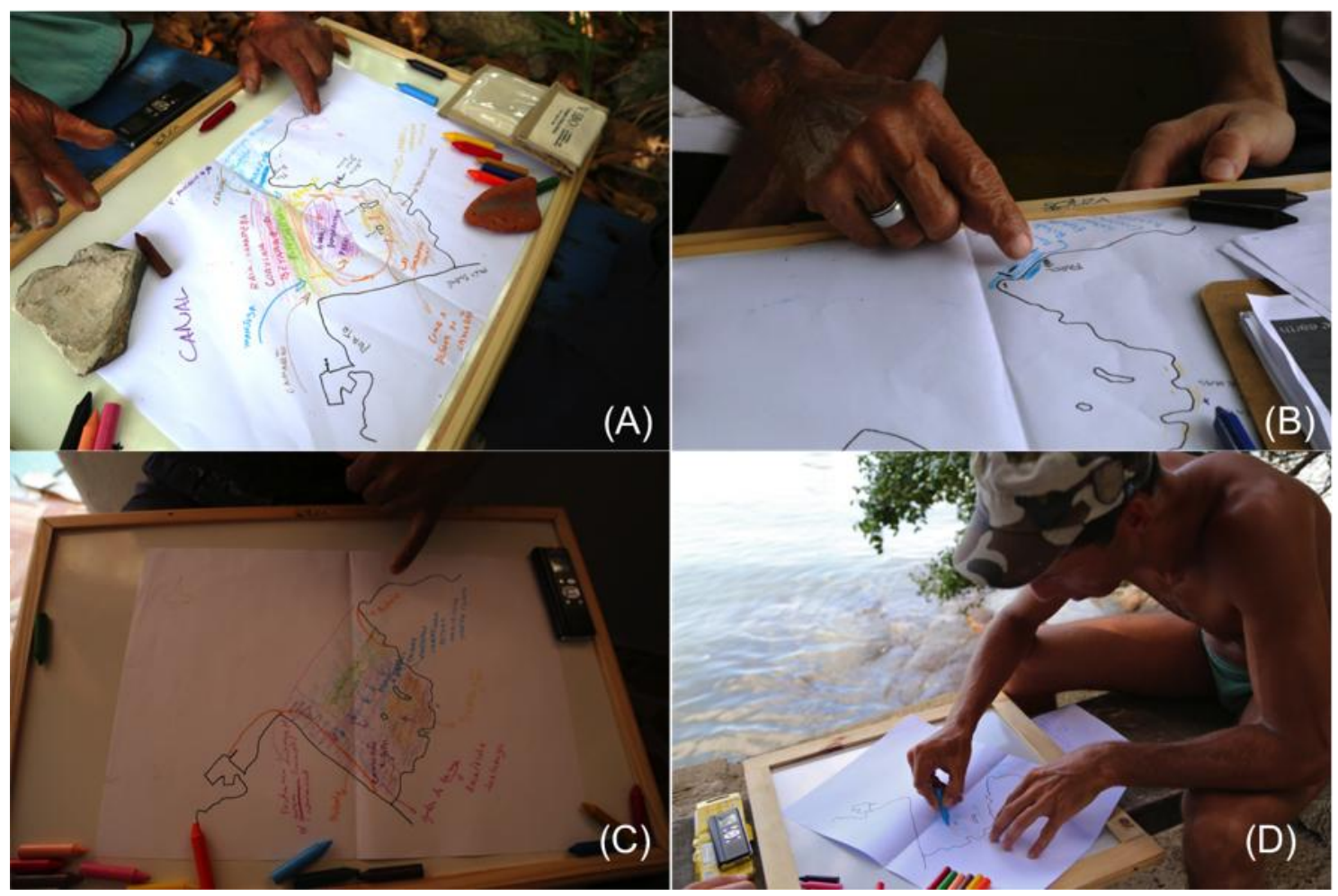

Figura 6: Diferentes mapas (A, B, C e D) desenhados pelos pescadores do Araçá.

\section{Métodos de análise das informações}

Em laboratório, todas as entrevistas foram transcritas integralmente e os resultados foram organizados e tabulados utilizando o software Excel. Após a 
organização desses resultados, seguiu-se com a análise das narrativas e depoimentos segundo o enfoque fenomenológico (MARTINS, 1994; MERLEAU-PONTY, 1999; MOREIRA, 2004; MARTINEZ, 2012). No enfoque fenomenológico, conforme a interpretação de Merleau-Ponty, deve-se buscar compreender o objeto ou fenômeno a ser investigado da maneira como ele é experimentado/vivido pelos indivíduos, despindo-se de pré-conceitos e "estando aberto a qualquer tipo de visão, tema ou conteúdo" (MARTINEZ, 2012, p.19).

Partindo dessas premissas, seguiu-se a análise, redução e tradução do significado das narrativas a partir da subdivisão dos discursos em movimentos, cujos significados são analisados descritivamente para, então, retomar a hipótese do trabalho (MOREIRA, 2004). Deste modo, as diversas falas registradas puderam ser selecionadas e agrupadas por temas, facilitando a identificação dos elementos de interesse nessa investigação (STORI, 2010). Nenhuma análise quantitativa foi realizada e, embora tenham sido conduzidas algumas quantificações, estas foram realizadas com o maior cuidado possível para que a dimensão humana não se diluísse no manancial numérico, seguindo os conselhos de MARQUES (2001, p.51).

Por se tratar de um grande volume de informações, os resultados obtidos foram divididos e agrupados por temas em três grandes grupos que, no entanto, seguem uma ordem diferente daquela apresentada no questionário utilizado durante as entrevistas. A saber:

- Parte I - Informações sobre os pescadores e a pesca na Baía do Araçá: naturalidade, escolaridade, renda e atividades econômicas praticadas; e informações sobre a pesca: regularidade/frequência com que os pescadores costumam pescar, locais/território de pesca, estratégias e artes de pesca utilizadas, e regras e estratégias de manejo tradicionais locais.

- Parte II - Informações sobre o conhecimento etnooceanográfico dos pescadores: etnoespécies ${ }^{4}$ da fauna aquática local conhecidas e capturadas; características do comportamento e dos habitats preferenciais utilizados pelas principais etnoespécies capturadas; e fenômenos físico-oceanográficos conhecidos pelos 
pescadores e sua influência na pesca.

- Parte III - Informações sobre as percepções e opiniões dos pescadores a respeito de: importâncias, potencialidades problemas e vulnerabilidades atreladas associadas ao Araçá; mudanças que ocorreram na pesca e tendências futuras; possibilidades de criação de áreas de restrição pesqueira; perspectivas futuras desejadas para a região; e responsáveis por agir.

Com relação aos mapas falados, esses foram digitalizados e vetorizados através da utilização dois softwares de geoprocessamento, o ArcGIS e o Google Earth Pro. Após a vetorização de todos os elementos que foram desenhados pelos pescadores em seus mapas, seguiu-se um processo de simplificação e análise dessas diversas representações. Tal processo consistiu na identificação e agrupamento de temas e aspectos comuns representados pelos pescadores, e na padronização dos elementos utilizados (símbolos e cores). Deste modo, a partir do agrupamento e da síntese dos mapas desenhados pelos pescadores, foi possível construir novos mapas organizados de acordo com os temas abordados nessa pesquisa.

Esses novos mapas, que foram compostos a partir das interpretações e representações dos pescadores, tiveram como objetivo simbolizar e representar aspectos locais como, por exemplo: áreas utilizadas como território pesqueiro; habitats das principais etnoespécies capturadas de peixes e invertebrados; e os padrões de movimento e circulação das águas. Tais mapas serviram para complementar as informações etnoocenográficas obtidas ao longo das entrevistas, bem como subsidiar as discussões sobre o ambiente local e sobre e suas características, segundo a visão e o conhecimento dos pescadores.

\section{Aplicação dos modelos de planejamento SWOT e DPSIR}

Apenas após a realização da análise das informações obtidas nas entrevistas e mapas falados é que se prosseguiu para a aplicação dos modelos conceituais SWOT e DPSIR.

A análise SWOT (strengths, weaknesses, opportunities, and threats), traduzida como análise FOFA, ou FFOA (Fortalezas, Fraquezas, 
Oportunidades e Ameaças), é um modelo analítico amplamente utilizado para subsidiar os processos de planejamento e de gestão estratégica (PICKTON; WRIGHT, 1998; SRIVASTAVA et al., 2005; BUARQUE, 2008; COWX et al., 2010), que se baseia na construção de diagramas na forma de matriz (Figura 7) ou tabelas. Tal modelo é usado para categorizar fatores endógenos e exógenos de um dado cenário ou ambiente, que, por sua vez, constituem suas fortalezas e fraquezas (elementos internos), e oportunidades e ameaças (elementos externos) (PICKTON; WRIGHT, 1998; SRIVASTAVA et al., 2005; COWX et al., 2010). A partir da distribuição dos componentes analisados em blocos é possível ter uma percepção mais clara dos fatores (positivos e negativos) que influenciam o ambiente local, facilitando a tomada de decisão (BUARQUE, 2008). No contexto da sustentabilidade e da gestão costeira integrada, gestores e tomadores de decisão podem basear-se nesse modelo para propor ações que maximizem os fatores positivos (potencialidades e oportunidades) da região de interesse, e minimizem os fatores negativos existentes (fragilidades e ameaças) (VIEGAS et al., 2014).

\section{Organização da matriz SWOT}

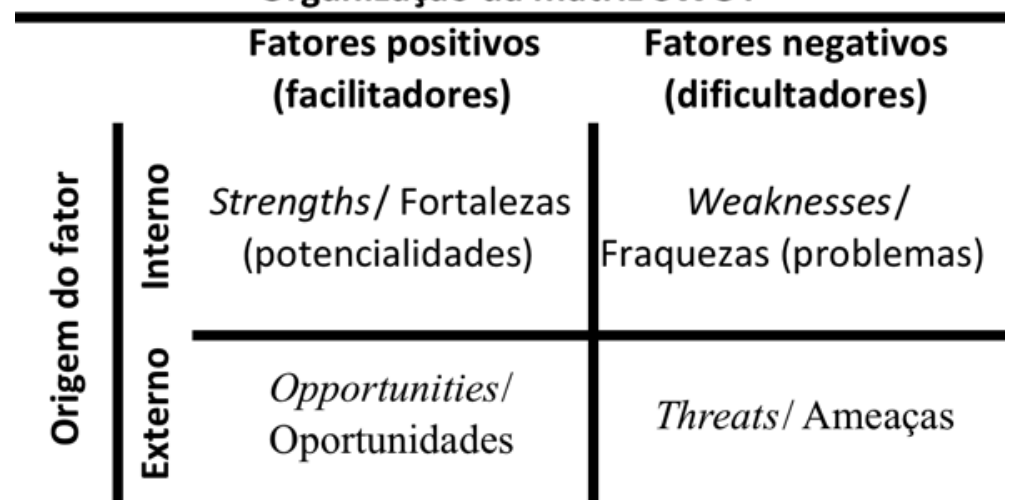

Figura 7: Esquema de organização da matriz SWOT. Adaptado de BUARQUE (2008).

Já o DPSIR (Driving forces - Pressures - States - Impacts -Responses) é um modelo conceitual abrangente construído por cinco categorias de informações, as quais visam identificar: os eventos e forçantes indutores de mudança (de origem antrópica) sobre um dado ambiente; as pressões atuantes no cenário estudado; o estado desse ambiente nesse cenário; os impactos resultantes; e as respostas da sociedade frente as mudanças observadas (SMEETS; WETERINGS, 1999; GABRIELSEN; BOSCH, 2003; KRISTENSEN, 2004; NESS et al., 2010). A partir desse modelo (Figura 8) é possível descrever as relações entre as origens e consequências de problemas ambientais, 
captando relações chave entre sociedade e ambiente (CARR et al., 2007; NESS et al., 2010; ATKINS et al., 2011; XAVIER; TURRA, 2013). Dessa forma, o DPSIR integra o conhecimento de diferentes áreas, abrangendo informações econômicas, sociais e ambientais com a finalidade de subsidiar análises mais detalhadas para a tomada de decisão (BIDONE; LACERDA, 2004; LUNDBERG, 2005). Assim, o DPSIR é uma ferramenta que tem sido constantemente utilizada para a estruturação de políticas públicas ambientais e pode ser de grande valor quando aplicada no contexto da gestão integrada (CARR et al., 2007; ATKINS et al., 2011; XAVIER; TURRA, 2013).

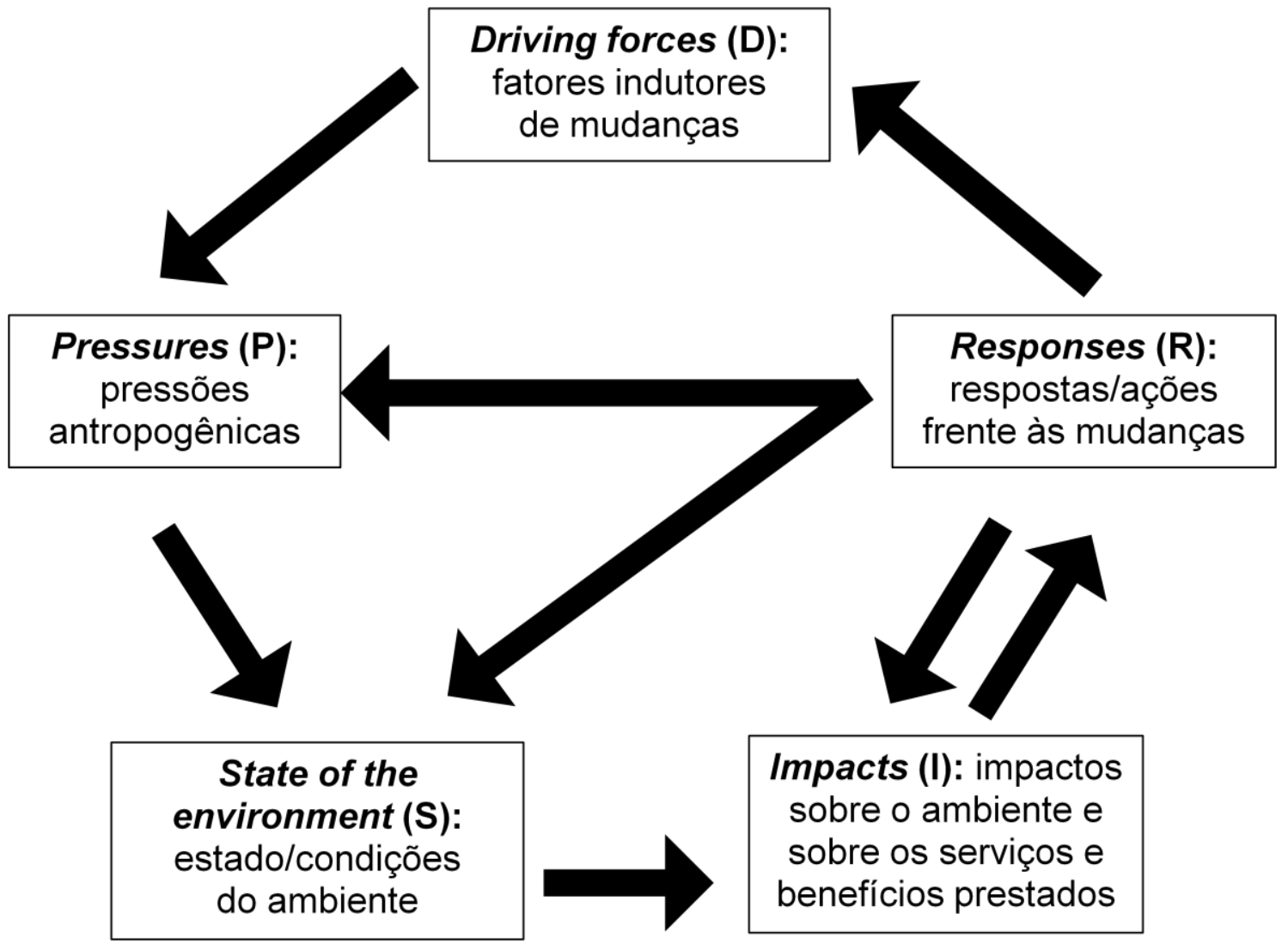

Figura 8: Estrutura do modelo conceitual DPSIR. Adaptado de ATKINS (2011).

$\mathrm{Na}$ aplicação do SWOT e do DPSIR, parte das informações registradas nas entrevistas e analisadas segundo o enfoque fenomenológico, foram agrupadas e divididas seguindo as categorias/conjuntos conceituais correspondentes em cada modelo. $\mathrm{Na}$ análise SWOT, elementos das entrevistas que indicassem fatores positivos e negativos relacionadas a Baía do Araçá foram identificados e distribuídos (em uma tabela) de acordo com sua posição, endógena (interna) ou exógena (externa) em relação ao ambiente. No DPSIR, o procedimento foi similar, porém seguindo as categorias próprias 
desse modelo, buscando demonstrar relações de causa/efeito relacionadas às origens e consequências de problemas locais identificadas pelos entrevistados. Ambos os modelos foram aplicados visando a sistematização de parte do volume de informações obtidas e analisadas nessa pesquisa, e tendo como foco a facilitação do uso dessas informações em processos planejamento e tomada de decisão. 


\section{RESULTADOS}

\section{OS PESCADORES E A PESCA NO ARAÇÁ}

\section{Os pescadores do Araçá}

Ao todo, entre setembro de 2014 e maio de 2015, foram entrevistados 18 pescadores artesanais (todos do sexo masculino) que usam a Baía do Araçá como território pesqueiro, e que foram apontados por eles próprios, ou por moradores antigos da região, como possuidores de uma considerável experiência e conhecimento sobre o ambiente local ("local experts"). Todos residem em casas simples, localizadas nos bairros do entorno da baía (bairros Varadouro e Topolândia), que compõe a área urbana da região central de São Sebastião (Figura 9). Atualmente, além do próprio Porto de São Sebastião, existem diversos comércios e empresas instaladas nessa região, muitas das quais localizadas ao longo da Rodovia Rio-Santos, no trecho que percorre o entorno da Baía do Araçá. Ainda assim, quase metade dos pescadores entrevistados (8 ao todo) e suas famílias, conseguiram se manter nas áreas originais ocupadas por seus pais e avós, e permanecem residindo em terrenos localizados em frente ao mar.

Todos afirmaram que gostam do lugar e que pretendem continuar morando e vivendo na região, citando como principais motivos: a pesca; a tradição; o senso de pertencimento e identificação com o lugar; o contato com a natureza; o lazer; a tranquilidade; e o acesso a serviços públicos (escolas, pronto socorro, etc.) e ao mercado de trabalho, conforme exemplificado nas seguintes falas:

Sou daqui, minhas raízes são aqui... (Pescador 7, 56 anos).

Nasci e fui criado aqui né. (...) Aqui é bom... Tem escola, tem mercado de trabalho... (Pescador 6, 31 anos).

Aqui tem a tradição do pescador né... (Pescador 14, 58 anos).

Aqui é onde nasci e me identifico, por causa da pesca, mergulho, clima... (Pescador 12, 37 anos).

É aqui que a gente tem saúde porque em outro lugar a 
gente não tem, a gente não se adapta... (Pescador 3, 72 anos).

Se eu sair daqui é como se fosse um peixe fora d'água... (Pescador 16, 62 anos).

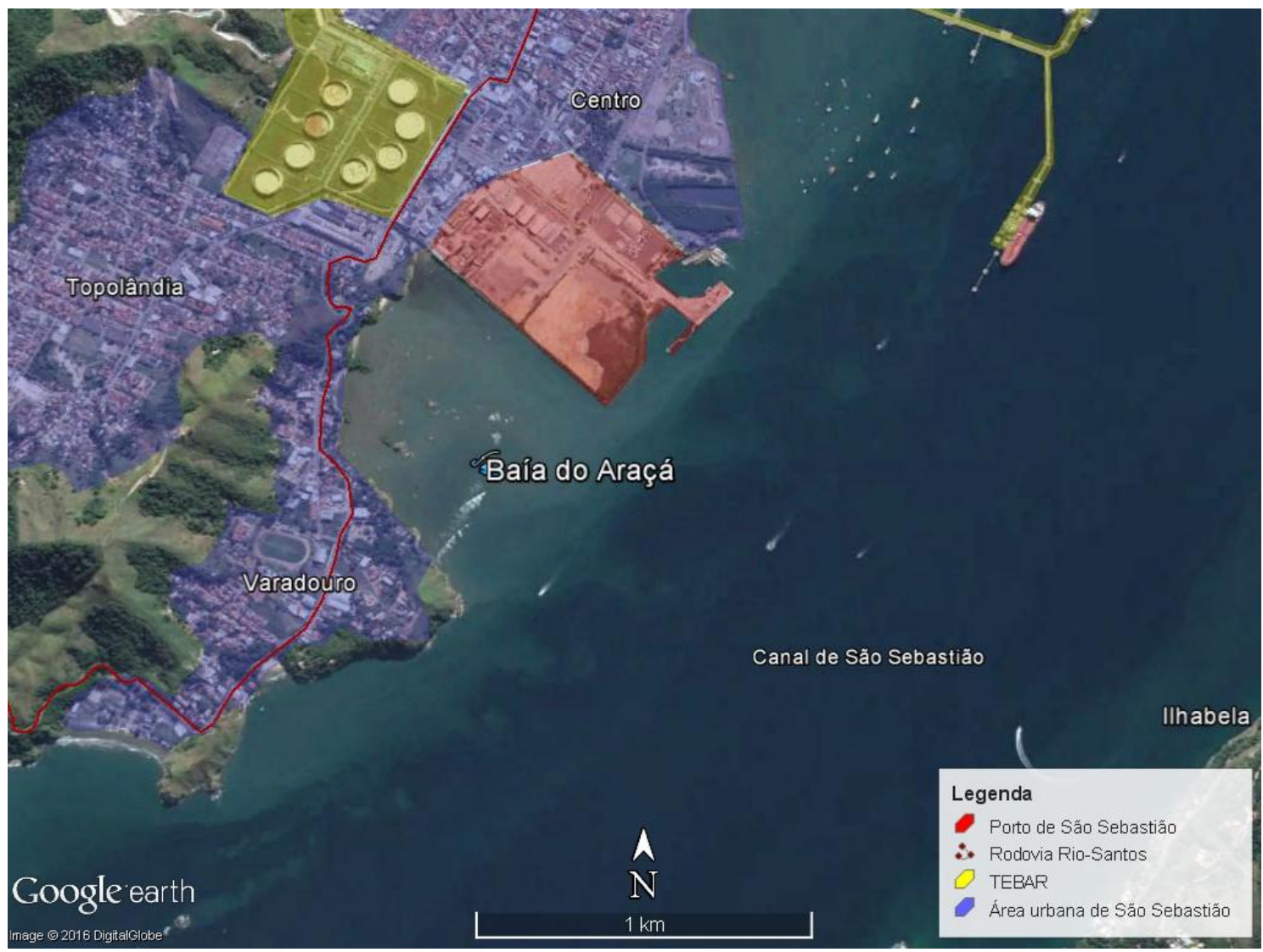

Figura 9: Localização da Baía do Araçá, dos bairros Varadouro e Topolândia, da Rodovia RioSantos, do Porto de São Sebastião e do TEBAR.

Ao serem perguntados se consideravam-se caiçaras, os pescadores foram unânimes em afirmar que sim, mesmo vivendo em uma área urbana e tendo seu dia-a-dia ligado ao cotidiano da cidade. Todos demonstraram um grande orgulho em ser caiçara, identificando-se com diversos traços dessa cultura tradicional. Para eles a cultura caiçara está relacionada, principalmente, com a vida em constante contato com mar, com a tradição da pesca artesanal e da canoa (Figura 10), com a culinária (Figura 11) e com o jeito simples e alegre. Tais aspectos podem ser evidenciados nos trechos de depoimentos apresentados a seguir:

Sou um caiçara! (...) Caiçara é você viver em constante contato com a natureza, com a pesca... (Pescador 8, 43 anos)

Sou caiçara nato! Ser caiçara eu não saberia nem te falar ao certo. Todos o ribeirinhos de beira de mar são caiçaras. São pessoas muito dadas, alegres, risonhas, 
espontâneas... (Pescador 15, 61 anos)

Ser caiçara é estar sempre em contato com o mar. Pescando, catando siri, fazendo o que o caiçara realmente gosta de fazer que é pescar. (Pescador 14, 58 anos)

Pra mim o caiçara é isso aí... A rede de pesca, a canoa, a gente não deixa da tradição da canoa de madeira... Meu irmão fala pra ir de lanchinha quando vou mergulhar, mas eu prefiro ir remando de canoa... (Pescador 11, 44 anos)

Ser caiçara é o simples fato de você ser nascido e criado num ambiente que é praiano e cultivar essa cultura que é caiçara. É você sair, mariscar, deixar uma rede de espera, comer o que pescou, os frutos do mar... (Pescador 13, 27 anos)

Ser caiçara é ser pescador, amar suas origens, seus ancestrais, a cultura, a culinária, seu local de criação e sobrevivência... É tudo isso. (Pescador 10, 45 anos)

É ser criado perto da praia, pescar uns peixes e o camarão. Manter esse modo de vida simples... (Pescador 17, 33 anos)

Já vem desde os pais que já estavam aqui... Ai passaram pra gente o cotidiano, desde os brinquedos que eram criados por nós mesmos... (Pescador 8, 43 anos) 


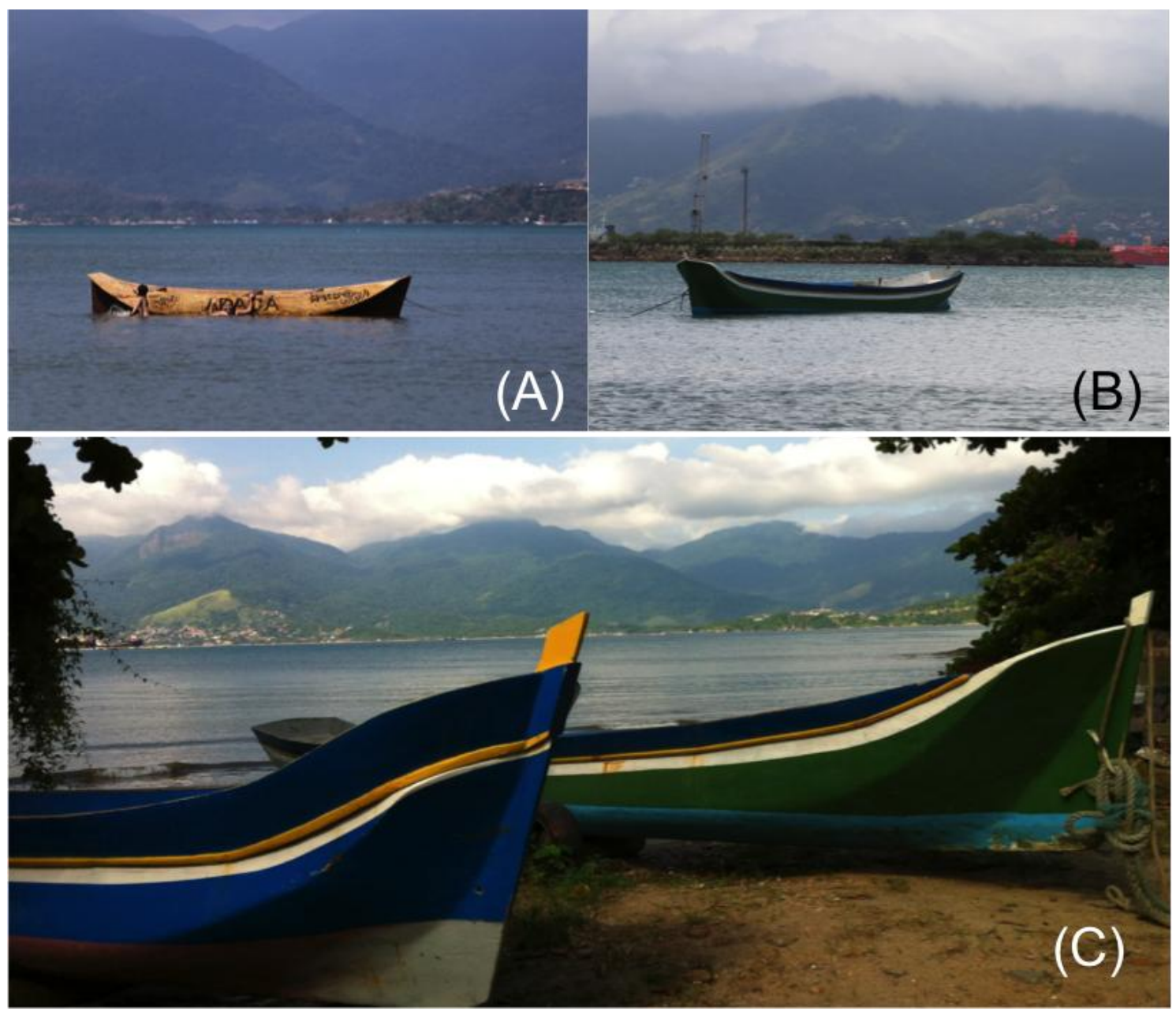

Figura 10: Canoas caiçaras (A, B e C) dos pescadores da Baía do Araçá. Autor(a): (A e B) Fernanda T. Stori (São Sebastião, março de 2015); e (C) Caiuá M. Peres (São Sebastião, outubro de 2014).
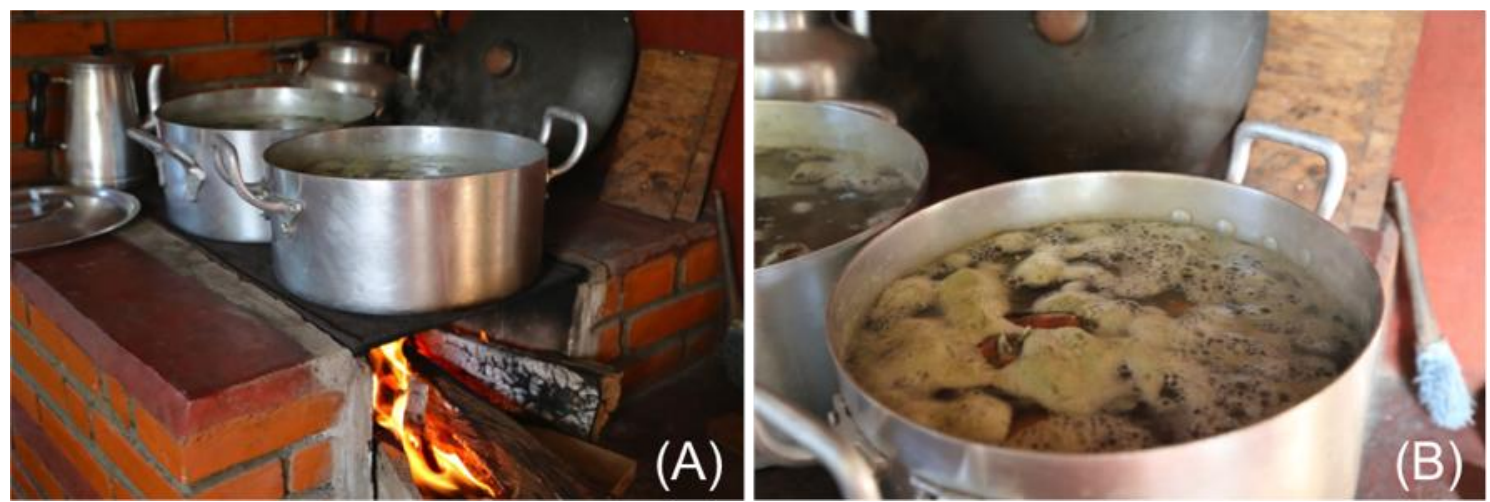

Figura 11: Fogão a lenha $(A)$ e mariscos sendo preparados $(B)$ ao modo tradicional caiçara, na casa de um dos pescadores entrevistados. Autor(a): (A e B) Fernanda T. Stori (São Sebastião, março de 2015).

Dentre os 18 entrevistados, o mais jovem possui 27 anos e o mais velho 72 anos. A maioria (14) possui idade superior a 35 anos e, desses, 7 possuem idade superior a 55 anos (Figura 12A). Todos são nativos da região costeira sendo que 13 nasceram no próprio município de São Sebastião, 4 no município 
de Ilhabela e 1 no município de Santos. A maioria sempre viveu nos bairros que compõe a área urbana no entorno da baía e aqueles que nasceram em outras localidades, vivem nessa região a muitos anos e passaram a maior parte da vida ali, onde construíram laços e uma grande identificação.

O nível de escolaridade entre os pescadores foi uma característica bastante variável, embora todos sejam alfabetizados e muitos tenham concluído pelo menos o ensino fundamental (Figura 12B). Mais da metade (10) concluiu o ensino médio e, desses, 2 também conseguiram concluir o ensino superior (Figura 12B).

A renda média bruta mensal declarada pelos entrevistados foi dividida em classes distribuídas em função do valor do salário mínimo (SM). Considerando que o valor do salário mínimo equivalia a 724,00 reais em 2014 (época das entrevistas), 6 entrevistados declararam possuir uma renda de até 2 SMs e 9 (metade) declararam ter uma renda entre 2 e 4 SMs (Figura 12C). Apenas 3 entrevistados afirmaram ter uma renda entre 4 e 10 SMs e ninguém declarou ter renda superior à10 SMs. Quando questionados se a pesca é sua fonte de renda principal, apenas 4 pescadores responderam afirmativamente (Figura 12D). Entre os demais, 9 afirmaram que a pesca é uma fonte de renda complementar (secundária) e 5 consideraram que a pesca não é uma fonte de renda (Figura 15). Desse total de 14 pescadores cuja pesca apenas complementa ou não contribui para a renda pessoal, 11 declararam possuir algum emprego formal ligado a outras atividades econômicas existentes no município (a saber: vigia em condomínio [1], professor [1], inspetor de escola [1], salva-vidas [1], vendedor [1], repositor de estoque em supermercado [1], representante comercial [1], operador de máquinas e equipamentos em terminais portuários [3], técnico em energia e gás [1]) e três declararam serem aposentados. 

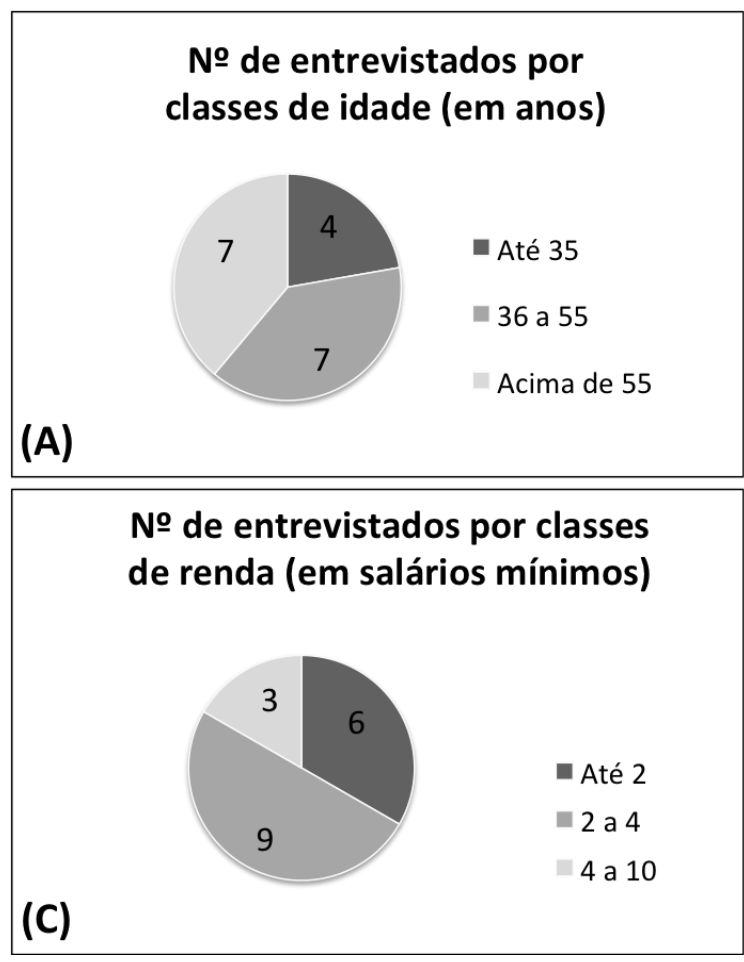

Figura 12: Distribuição dos entrevistados $(n=18)$ segundo: $(A)$ classes de idade; (B) grau de escolaridade (completo ou incompleto); (C) classe de renda média bruta mensal declarada (em função do salário mínimo); e (D) relação econômica com a atividade pesqueira.

Ainda que os pescadores do Araçá apresentem diferenças em relação ao papel econômico da pesca em suas vidas, há um compartilhamento da visão de que a tal prática é, fundamentalmente, uma atividade tradicional de subsistência que provém alimentos para consumo próprio e de sua família. Tal visão pode ser elucidada em alguns trechos das entrevistas apresentadas abaixo:

Pesco pra fomentar a minha cultura. (...) Mais pra se alimentar mesmo. Eu não pego de quantidade, só o suficiente pra matar a minha necessidade... (Pescador 9, 41 anos)

É mais pra consumo próprio... Mas também dá pra tirar uma renda... (Pescador 1, 49 anos)

Além de ter o alimento, peixe fresco, a pesca também me ajuda a complementar minha renda... (Pescador 12, 37 anos)

Todos afirmaram ter aprendido a pescar ainda na infância com pescadores antigos, geralmente o pai ou outros familiares mais velhos como avôs e tios. As formas de aprendizagem mais citadas pelos mesmos, foram a observação e experimentação prática seguindo o exemplo desses pescadores 
antigos. Não foi incomum um ou outro entrevistado afirmar que aprendeu a pescar sozinho, embora tenham admitido que, no início, observavam os mais experientes e acompanhavam seus passos. Todos também afirmaram já terem ensinado outras pessoas a pescar, normalmente os filhos, sobrinhos, vizinhos, amigos e até "pessoas de fora". Os trechos de falas destacadas adiante são exemplos dessas afirmações realizadas pelos pescadores entrevistados:

Acho que desde que comecei a andar eu comecei a pescar... (Pescador 9, 41 anos)

Pesco desde quando me entendi por gente... (Pescador 3, 72 anos)

Aprendi com meu pai, meu avô, pescadores antigos... (Pescador 16, 62 anos)

Papai levava agente pra largar rede, picaré, rede de tráia, rede de cerco, várias modalidades. (Pescador 3, 72 anos)

Agente aprende na convivência. Agente vai olhando e vai aprendendo, assim como eu mesmo aprendi. (Pescador 3, 72 anos)

Comecei com meu pai, mas aprendi sozinho. (Pescador 4, 30 anos)

Meus sobrinhos aprenderam comigo, iam aprendendo olhando, na prática... Um ajudava uma coisa e outro na outra... (Pescador 3, 72 anos)

Já ensinei meu filho, meus sobrinhos, pessoas de fora... (Pescador 5, 68 anos)

\section{O território pesqueiro do Araçá}

A área interna da Baía do Araçá, assim como áreas adjacentes (mais profundas), que ficam no entorno da Ponta do Araçá, da Praia Preta e do Farol do Moleque (ao longo do Canal de São Sebastião), foram os principais locais citados pelos entrevistados como sendo suas áreas de pesca:

Toda essa região aqui é meu palco de pegar peixe...

Essa aqui é nossa área de pesca... Não só minha mas de muita gente aqui... (Pescador 3, 72 anos)

Essa região toda aqui... Do farolzinho (Farol do Moleque) pra cá... E daqui pra dentro... (Pescador 15, 61 anos)

Outros locais como a regiões das praias de Guaecá e Toque-toque em São Sebastião, e da Praia do Bonete em Ilhabela, também foram citadas por 47 
alguns pescadores como áreas de pesca. No entanto esses locais são pouco frequentados por eles (por serem mais afastados) e não são considerados como sendo parte "do Araçá".

O somatório das áreas de pesca consideradas pelos próprios pescadores como parte "do Araçá" (estabelecidas com base nos mapas falados), resultou numa delimitação aproximada do território pesqueiro da Baía do Araçá (Figura 13), com cerca de $2 \mathrm{~km}^{2}$.

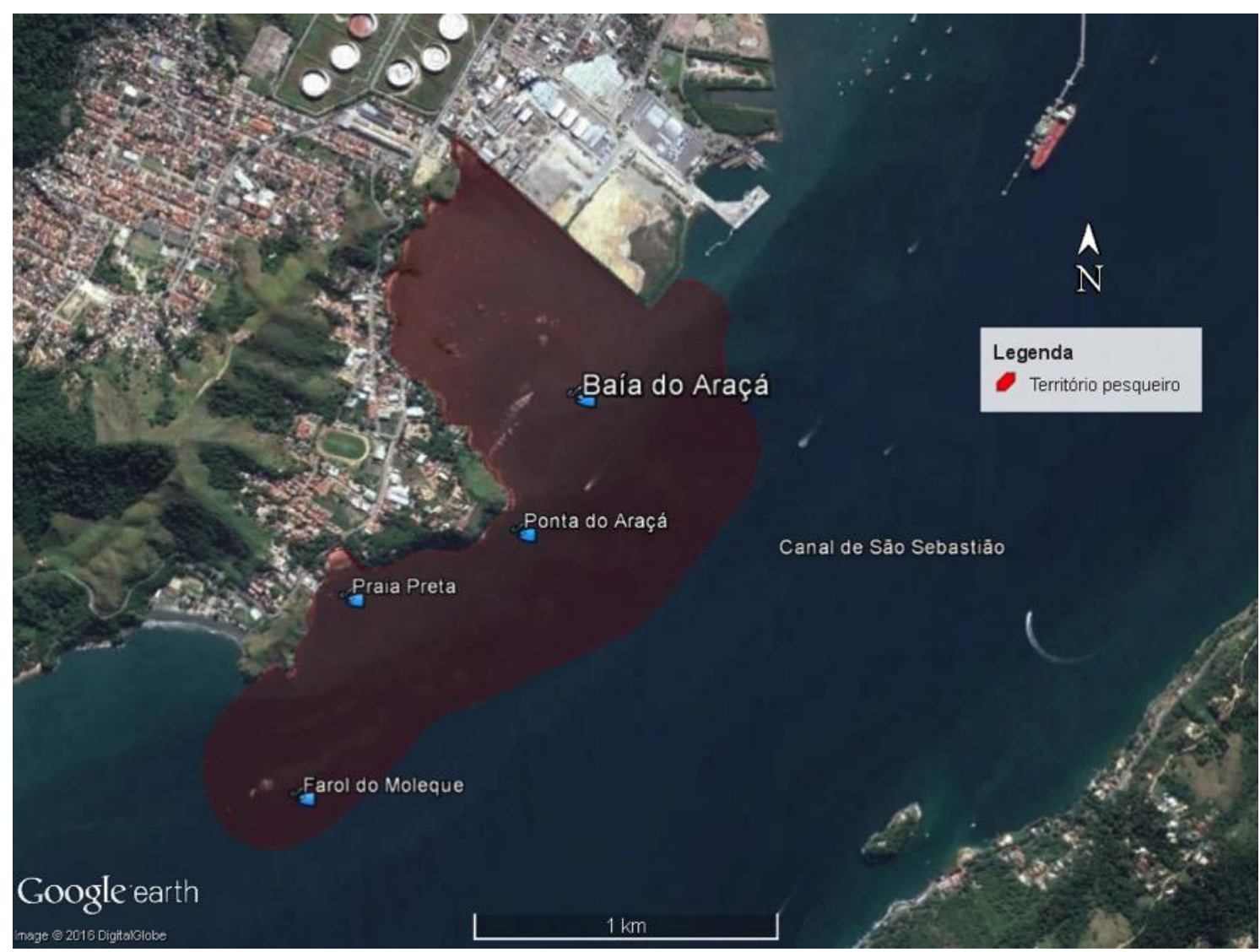

Figura 13: Delimitação aproximada do território pesqueiro dos pescadores da Baía do Araçá, estabelecido a partir dos mapas falados, com destaque para a localização da Ponta do Araçá, da Praia Preta e do Farol do Moleque.

Ainda que seja possível delimitar o território pesqueiro através da utilização de mapas, no mundo real esses limites são "imaginários". Desse modo, a identificação dos chamados pesqueiros (áreas preferenciais de pesca usadas pelos pescadores para captura de determinados tipos de organismos) é realizada, geralmente, através do sistema de marcações e triangulações utilizando referenciais em terra que sejam conhecidos e fáceis de reconhecer, tal qual exemplificado nas seguintes falas:

Tem lugares próprios pra pesca que a gente marca. $A$ gente faz marcações com os morros. Você rema tanto numa 
posição e faz o cruzamento das referências e sabe onde tem o pesqueiro... (Pescador 16, 62 anos)

Eu faço minhas marcas né, eu e meus irmãos... Uma casa de destaque, uma árvore. Nós temos uns pontos de referência né. Nada de coisa que se movimente né... (Pescador 3, 72 anos)

Embora os pesqueiros sejam locais de grande relevância para os pescadores, muitos ressaltaram que a totalidade desse espaço/território é fundamental para a manutenção e reprodução de sua tradição pesqueira, assim como nos exemplos abaixo:

Da terra pra laginha (uma das ilhotas) tem berbigão. $O$ siri é tanto aqui (entre a terra e as ilhas) como pra fora também tem, só que aqui tem mais... Os peixes tem por tudo isso... Então, de um modo geral, tudo é importante... (Pescador 8, 43 anos)

Para mim toda a baía é importante porque cada lado tem uma coisa diferente... (Pescador 11, 44 anos)

Nós aprendemos com nossos antepassados que a pesca, principalmente aqui na região da Baía do Araçá, tem que ter três itens: a ciência, a frequência e a paciência. $\mathrm{Na}$ pescaria pode acontecer de você sair hoje e não pegar nada. $O$ que acontece: o meu conhecimento, que a ciência abrange todas as qualidades, você fala hoje por um motivo tal, as águas estavam frias, o vento não estava próprio, vamos ver... Amanhã eu volto. Aí no outro dia eu vou e arrebento. Por quê? Aí chama-se a frequência, tem que frequentar todos os dias. Pega e não pega e tá lá, tem que bater cartão. Se não perde o dia... (Pescador 9, 41 anos)

\section{A pesca no Araçá}

A grande diversidade de habitats e de espécies da fauna aquática marinha existentes no território pesqueiro do Araçá possibilita que os pescadores locais pratiquem diversos tipos de pescarias, dependendo das espécies alvo e dos locais (pesqueiros) escolhidos para pescar. Conforme exposto nos trechos a seguir, existem diversos tipos de organismos capturados, os quais podem ser encontrados em diferentes locais: 
O foco de pescaria nessa área aqui (indicando a região entre as ilhas) é o parati... Aqui (perto do cais do porto) tem robalo... Pra cá (indicando outra área da baía) tem betara, vermelho, corvina, siri, espada, polvo, garoupa, cardume de caratinga, tainha... (Pescador 13, 27 anos)

Aqui você pega o parati... Vem também a enchova, a sororoca, a tainha, o xarelete, carapau... Tem também o vermelho, salemas... Uma infinidade... Os mais considerados são esses... Pra cá você tem o espada, que pega na linha também... (Pescador 16, 62 anos)

Nesse contexto, a utilização de diferentes estratégias e artes de pesca (Tabela 2) foi um aspecto de grande variação entre os entrevistados. Para eles, os principais fatores que influenciam a escolha do método pesqueiro a ser utilizado são: as espécies-alvo (p.ex: camarão, siri, peixes de fundo ou superfície); os locais de pesca (p. ex.: costões rochosos, parcéis e praias); e as condições do mar (p. ex.: altura das marés, direção correntes e turbidez). Além desses fatores, questões pessoais como o conhecimento e a habilidade que cada pescador possui, bem como a preferência por um ou outro tipo de método, local ou espécie alvo, também parecem influenciar essa escolha. Nas falas transcritas a seguir, alguns desses fatores que influenciam na escolha das estratégias pesqueiras podem ser observados:

Tanto aqui no aterro (costeira do enrocamento do porto) como aqui (costões rochosos próximos a Ponta do Araçá) agente faz o bate-costeira... Que é você pegar a rede com a canoa, larga em uma ponta e fecha na outra (cercando parte da costeira)... Aí você entra dentro e bate que eles correm pra rede... (...) Bem na frente da baía também tem tipo umas valas onde é bom pra pescar com borrachão (linha de fundo) e rede de fundo... (Pescador 8, 43 anos)

Quando chega a época de anchova que está pegando bastante ela tem a malha própria pra ela. Na tainha você tem outra rede, cada peixe tem uma... (Pescador 16, 62 anos)

Quando a água tá clara, de sul, e o mar calmo, geralmente vou pro mergulho (pesca subaquática)... (Pescador 13, 27 anos) 
Pesco camarão pra usar como isca de outras pescarias... Uso um puçá grande... A gente deixa eles (camarões) no samburá (Figura 14) e de manhã sai pra pescar (de linha) com eles vivos... (Pescador 1, 49 anos)

É lógico que depende do pescador... Você tem que chegar no lugar, fundear, jogar um engodozinho, esperar a vazante ou a enchente... Não é qualquer momento... Lua ótima é lua cheia... Essa época do verão é melhor também, época do frio é horrível! No calor, tem mais alimento (para os peixes)... (Pescador 3, 72 anos)

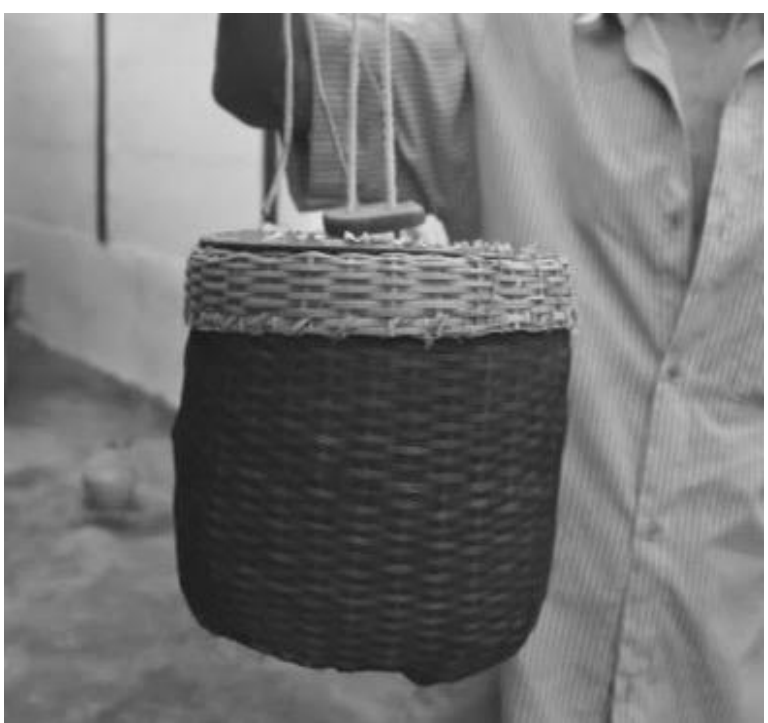

Figura 14: Samburá - cesto para armazenar o camarão vivo usado por um dos pescadores entrevistados. Autor(a): Fernanda T. Stori (São Sebastião, março de 2015). 
Tabela 2: Principais estratégias/artes de pesca utilizadas pelos pescadores da Baía do Araçá.

\begin{tabular}{|c|c|c|}
\hline $\begin{array}{l}\text { Estratégias/ } \\
\text { artes de pesca }\end{array}$ & Observações & $\begin{array}{l}\text { Referências feitas pelos pescadores } \\
\text { sobre as pescarias }\end{array}$ \\
\hline $\begin{array}{l}\text { Linha (linhada, } \\
\text { linha de mão, } \\
\text { molinete, } \\
\text { borrachão, etc.) }\end{array}$ & $\begin{array}{l}\text { Tipos de isca (viva ou } \\
\text { não) dependem da } \\
\text { espécie-alvo da } \\
\text { pescaria }\end{array}$ & $\begin{array}{l}\text { "A garoupa é na linha de mão com isca } \\
\text { de sardinha, bonito... Ela gosta de peixe } \\
\text { quando tá podre. (...) Já o robalo é } \\
\text { linhada com camarão vivo..." }\end{array}$ \\
\hline $\begin{array}{l}\text { Bate-costeira } \\
\text { (com rede) }\end{array}$ & $\begin{array}{l}\text { Estratégia de pesca } \\
\text { coletiva usada em volta } \\
\text { dos costões rochosos }\end{array}$ & $\begin{array}{l}\text { "Rede que você fecha a costeira de uma } \\
\text { ponta a outra... E fica bagunçando ali... } \\
\text { Bagunça lá dentro, joga pedra, aí os } \\
\text { peixes assustam e correm pra rede..." }\end{array}$ \\
\hline $\begin{array}{l}\text { Rede de } \\
\text { espera (Figura } \\
15 \text { ) }\end{array}$ & $\begin{array}{l}\text { Geralmente, é deixada } \\
\text { no anoitecer e retirada } \\
\text { de manhã }\end{array}$ & $\begin{array}{l}\text { "Quando entra a sardinha, a gente fecha } \\
\text { uma boa parte aqui perto da ponta do } \\
\text { Araçá com a rede de espera. Elas } \\
\text { passam e os outros ficam..." }\end{array}$ \\
\hline $\begin{array}{l}\text { Rede de cerco } \\
\text { ou cerco de } \\
\text { roda }\end{array}$ & $\begin{array}{l}\text { Usada para fechar } \\
\text { cardumes }\end{array}$ & $\begin{array}{l}\text { "O cerco de roda, a gente usa mais aqui } \\
\text { no meio. A gente vê o peixe, solta a } \\
\text { ponta da rede e circula o peixe. É mais } \\
\text { pra cercar cardume de parati e tainha... } \\
E \text { É mais de peixe boiado, que fica na } \\
\text { superfície..." }\end{array}$ \\
\hline $\begin{array}{l}\text { Pesca de } \\
\text { "caceio" }\end{array}$ & $\begin{array}{l}\text { Rede usada com a } \\
\text { "maré correndo" (a } \\
\text { rede é solta com a } \\
\text { correnteza) }\end{array}$ & $\begin{array}{l}\text { "A gente larga (a rede) daqui pra fora... } \\
\text { Aí a maré vai esticando ela... Quando ela } \\
\text { esticar, você já vai colhendo ela..." } \\
\text { "Geralmente soltamos aqui na frente... } \\
\text { Bem na boca aqui..." }\end{array}$ \\
\hline $\begin{array}{l}\text { Picaré ou } \\
\text { arrastão }\end{array}$ & $\begin{array}{l}\text { Arrasto de praia (pouco } \\
\text { usada pelos } \\
\text { pescadores) }\end{array}$ & $\begin{array}{l}\text { "As vezes passamos arrastão. Mas eu } \\
\text { não gosto porque pega muito os } \\
\text { pequenos. Com o puçá dá para devolver } \\
\text { os pequenos." }\end{array}$ \\
\hline $\begin{array}{l}\text { Puçá (Figura } \\
16)\end{array}$ & $\begin{array}{l}\text { Puçá grande de malha } \\
\text { fina feito } \\
\text { artesanalmente para } \\
\text { pesca do camarão }\end{array}$ & $\begin{array}{l}\text { "Quando tem muito camarão a gente usa } \\
\text { aquele puçá grande..." }\end{array}$ \\
\hline Tarrafa & $\begin{array}{l}\text { Usada para pescar } \\
\text { cardumes avistados na } \\
\text { superfície }\end{array}$ & $\begin{array}{l}\text { "A tarrafa você lança quando você avista } \\
\text { o cardume na superfície... Geralmente é } \\
\text { pra cardume de parati, tainha, } \\
\text { sardinha..." }\end{array}$ \\
\hline Bicheiro & $\begin{array}{l}\text { É um tipo de gancho } \\
\text { comprido de ferro } \\
\text { usado capturar polvos } \\
\text { e siris }\end{array}$ & $\begin{array}{l}\text { "O polvo eu pego mergulhando com o } \\
\text { bicheiro, que é uma varinha com um } \\
\text { anzol na ponta..." } \\
\text { "Siri...eu pego com um ganchinho } \\
\text { porque agente enxerga ele, então } \\
\text { precisa ter a água clara. Se a água tiver } \\
\text { escura você não pega ele porque não } \\
\text { enxerga... Maré não pode ser nem cheia } \\
\text { demais nem seca..." }\end{array}$ \\
\hline Rastelo & $\begin{array}{l}\text { Usado para mariscar } \\
\text { (ou catar mariscos) }\end{array}$ & $\begin{array}{l}\text { "O berbigão eu pego usando um garfo } \\
\text { ou um rastelinho pra não machucar a } \\
\text { mão..." }\end{array}$ \\
\hline
\end{tabular}


Tabela 2 (continuação): Principais estratégias/artes de pesca utilizadas pelos pescadores da Baía do Araçá.

\begin{tabular}{|c|c|c|}
\hline $\begin{array}{l}\text { Fisga (Figura } \\
17 \text { ) }\end{array}$ & $\begin{array}{l}\text { É um tipo de arpão com } \\
\text { a ponta em forma de } \\
\text { tridente - muito usada } \\
\text { para pegar } \\
\text { tamburutacas e siris }\end{array}$ & $\begin{array}{l}\text { "Tamburutaca eu pego com uma varinha } \\
\text { comprida que eu coloco dentro buraco. } \\
\text { Aí quando ela vem tirar a varinha pra } \\
\text { fora agente pega ela com a fisga..." }\end{array}$ \\
\hline $\begin{array}{l}\text { Iscas presas } \\
\text { em boias e } \\
\text { jereré (puçá } \\
\text { pequeno) }\end{array}$ & $\begin{array}{l}\text { Estratégia muito usada } \\
\text { para pegar siris (as } \\
\text { iscas atraem os siris } \\
\text { que são capturados } \\
\text { pelo puçá) }\end{array}$ & $\begin{array}{l}\text { "O puçá do siri é chamado de jererê..." } \\
\text { "Você usa isca e umas bóias... Eles } \\
\text { (siris) vem na isca e você pega com o } \\
\text { puçá..." }\end{array}$ \\
\hline $\begin{array}{l}\text { Faxiar (com } \\
\text { lampião e } \\
\text { puçá) }\end{array}$ & $\begin{array}{l}\text { Estratégia de pesca } \\
\text { noturna }\end{array}$ & $\begin{array}{l}\text { "Você sai a noite com um lampião na } \\
\text { frente do barco, remando devagarzinho, } \\
\text { com o mar calmo... Vou só com o puçá... } \\
\text { A luz cega o peixe e fica fácil de pegar... } \\
\text { Muito caiçara pescava assim } \\
\text { antigamente, porque não tinha rede..." }\end{array}$ \\
\hline Espinhel & $\begin{array}{l}\text { Técnica usada } \\
\text { principalmente nas } \\
\text { áreas adjacentes do } \\
\text { Canal de São } \\
\text { Sebastião }\end{array}$ & $\begin{array}{l}\text { "Pra pescar a garoupa eu usava o } \\
\text { espinhel de fundo... No canal aqui em } \\
\text { frente... Usa muito (espinhel) pra mata } \\
\text { garoupa, miracelo..." }\end{array}$ \\
\hline $\begin{array}{l}\text { Mergulho e } \\
\text { arbalete } \\
\text { (arpão) }\end{array}$ & $\begin{array}{l}\text { Praticado } \\
\text { principalmente nas } \\
\text { áreas de parcéis } \\
\text { próximas a ponta do } \\
\text { Araçá }\end{array}$ & $\begin{array}{l}\text { "Robalo, badejo, garoupa, pego tudo no } \\
\text { mergulho, com arpão... Basta ter água } \\
\text { clara..." }\end{array}$ \\
\hline
\end{tabular}

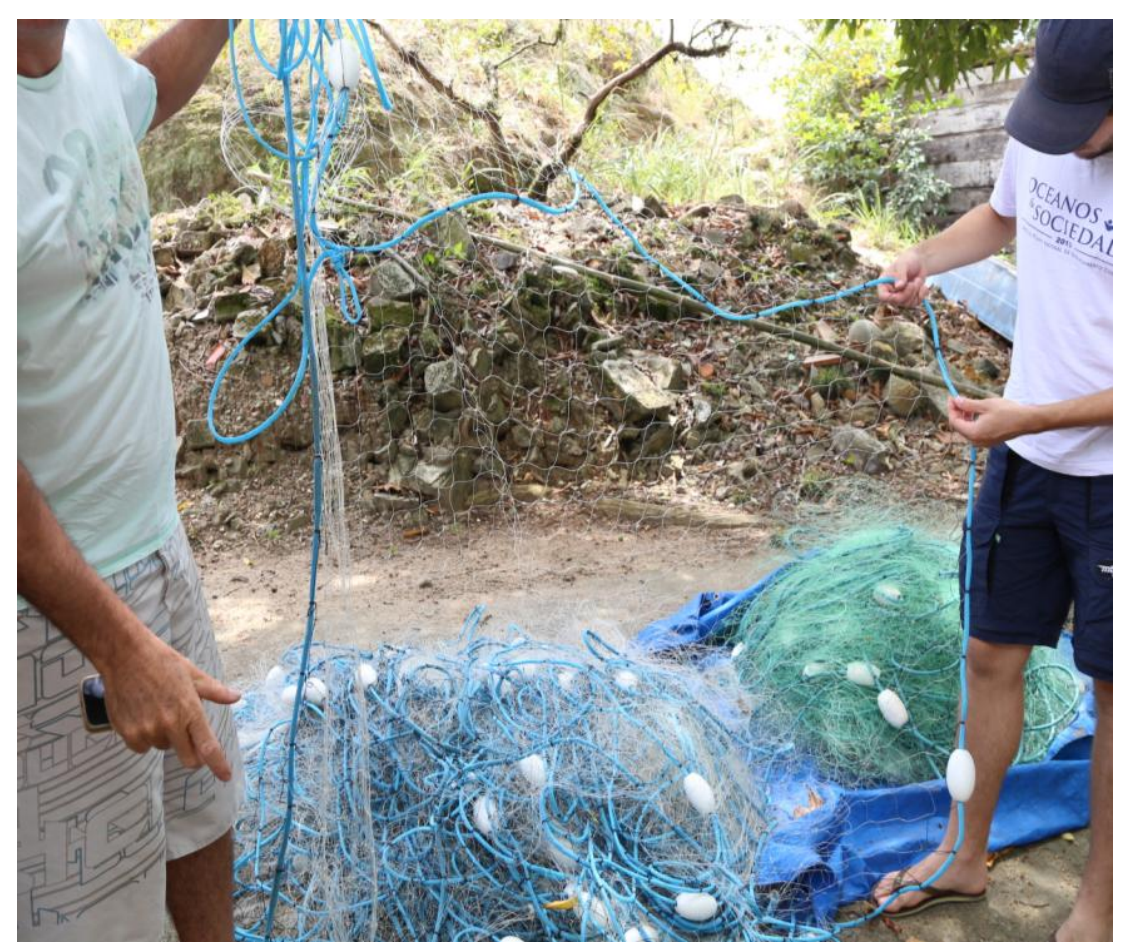

Figura 15: Redes de espera de diferentes tamanhos e malhas utilizadas na pesca no Araçá. Autor(a): Fernanda T. Stori (São Sebastião, outubro de 2014). 

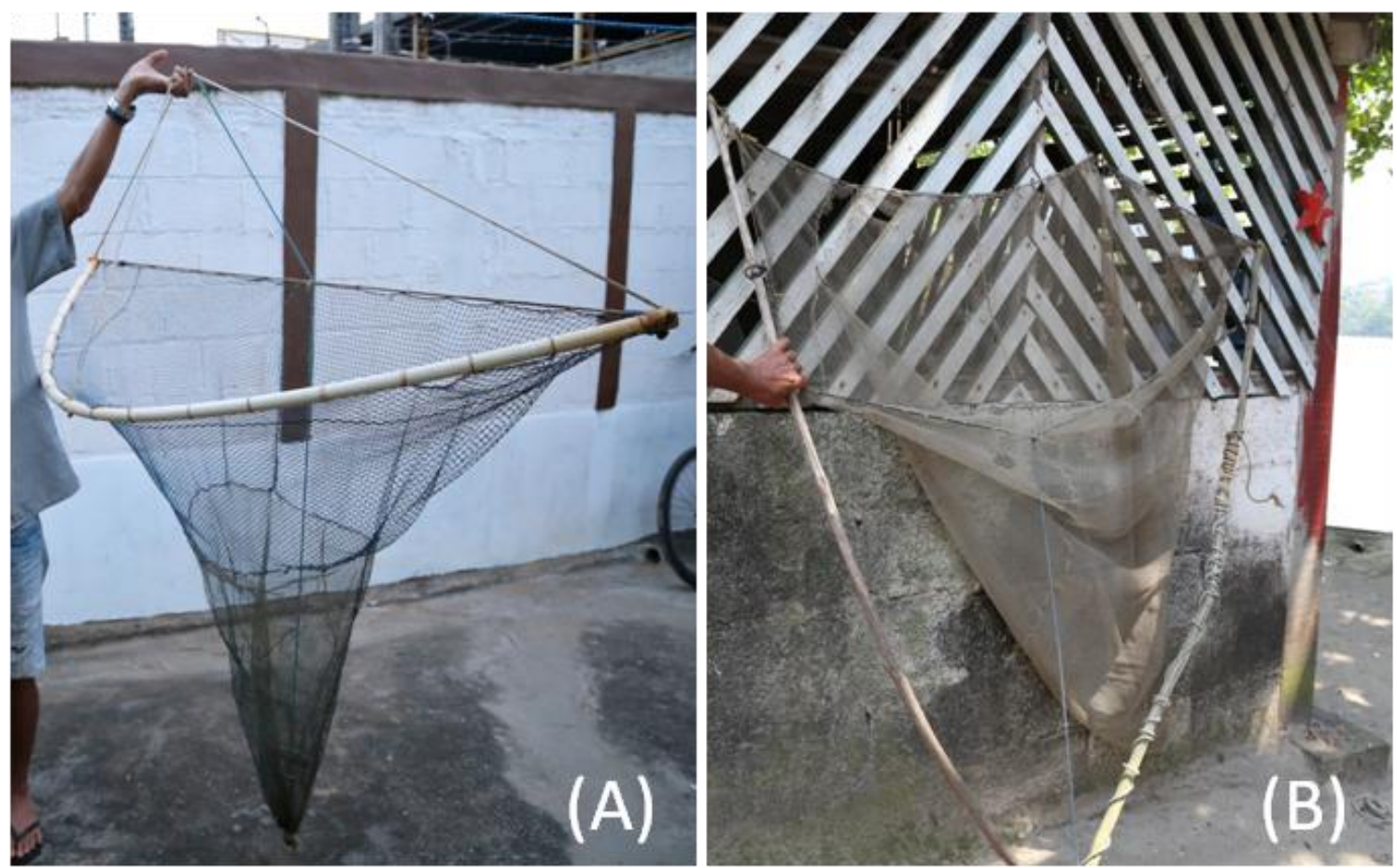

Figura 16: Puçás ( $A$ e B) feitos artesanalmente pelos próprios pescadores e utilizados na pesca do camarão (para usá-los como isca viva). Autor(a): (A, B) Fernanda T. Stori, (São Sebastião, março de 2015).

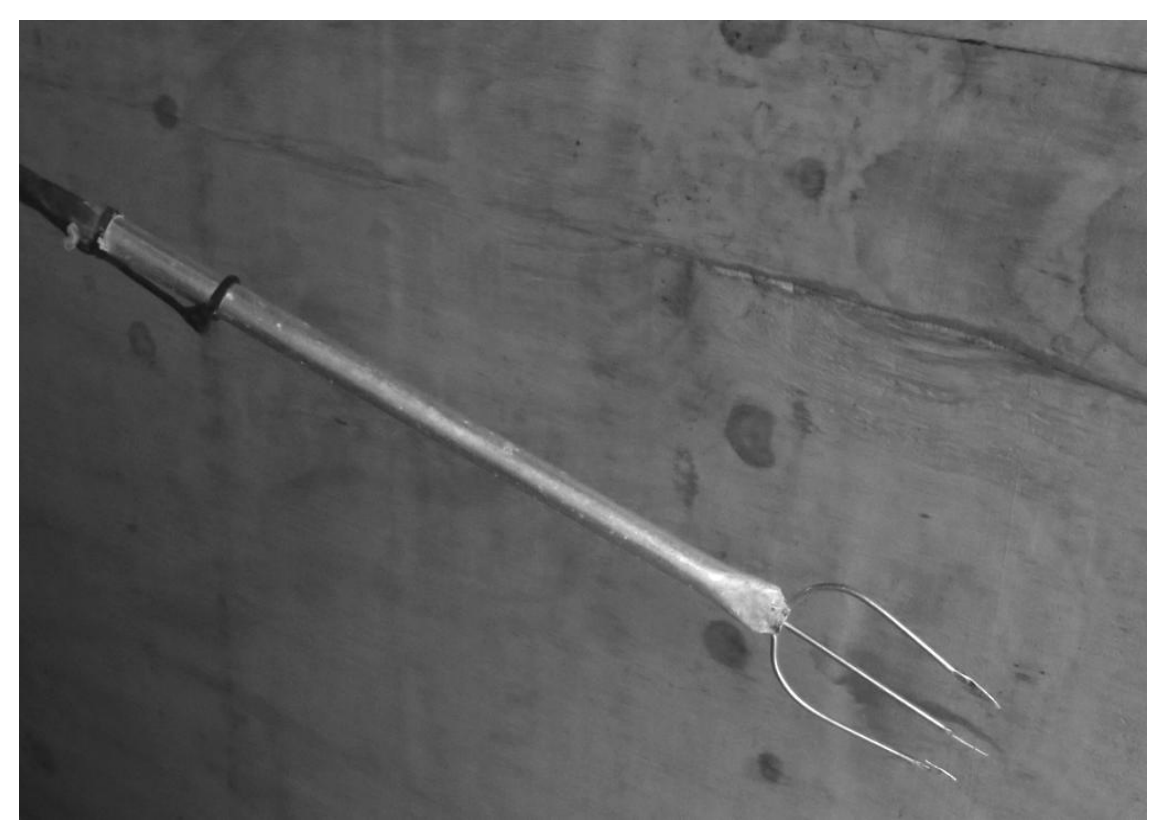

Figura 17: Ponta da fisga na forma de tridente em detalhe (A), e fisga sendo utilizada para captura do siri (B). Autor(a): Fernanda T. Stori (São Sebastião, outubro de 2014). 
No Araçá, a realização da pesca embarcada não motorizada foi amplamente citada pelos pescadores locais. Tal característica deve-se, provavelmente, pelo fato de as distâncias percorridas serem relativamente pequenas e pelo fato de que os pescadores pescam, predominantemente, para subsistência própria. Muitos também afirmaram praticar a pesca desembarcada (mesmo tendo acesso a embarcações), aproveitando locais de baixa profundidade (como no caso da pesca do camarão, utilizando o puçá, ou do siri, utilizando a fisga), e as pontas de costões rochosos onde os pescadores sabem que há passagem constante de cardumes (como no caso da Ponta do Araçá). Aqueles que têm acesso a embarcações motorizadas, normalmente, fazem seu uso para se dirigir a regiões como a praia do Bonete (em Ilhabela) ou as praias de Guaecá e Toque-toque (em São Sebastião), fora da região do Araçá.

Ao todo, 15 pescadores afirmaram possuir algum tipo de embarcação, sendo a maioria de pequeno porte (principalmente pequenas lanchas e canoas a remo). Os que não possuem embarcação afirmaram que costumam emprestar de familiares ou amigos. Por serem, em sua maioria, embarcações pequenas, os pescadores costumam guardá-las em suas próprias casas quando não estão sendo utilizadas (Figura 18). Os que não tem como guardar a embarcação em casa a deixam em ranchos, nas praias, ou fundeadas nas águas rasas da baía (Figura 19), conforme mencionado por alguns entrevistados:.

Tenho uma (canoa) que uso mas que não é minha. É de um amigo meu... Ela fica aqui em casa... (Pescador 4, 30 anos)

Meu barco fica aqui em casa no quintal... E as vezes fica ali fora na água, bem aqui na frente... (Pescador 1, 49 anos)

Quando a gente faz a pesca da garoupa que a gente sai bastante eu até deixo ele na boia por uns dias. É do meu patrão mas quem usa mesmo sou eu... (Pescador 2, 60 anos)

Geralmente deixo na água mesmo... Porque é uma enseada abrigada, calma... Senão fica lá em casa... (Pescador 14, 58 anos)

Os motivos mais citados como favoráveis para a guarda de 
embarcações no Araçá foram o acesso fácil e o fato de as águas serem calmas e protegidas: "Minha canoa fica no rancho... Ali tem facilidade pra sair pra pescar e retornar... Fica próximo da praia e o lugar faz parte da propriedade da família..." (Pescador 16, 62 anos). No entanto, o risco de vandalismo e depredação foi citado como um fator negativo, com o qual os pescadores se preocupam e, por isso, preferem deixar em casa: "A minha canoa fica em casa mesmo... Não deixo na água porque tem muito vandalismo..." (Pescador 15, 61 anos).

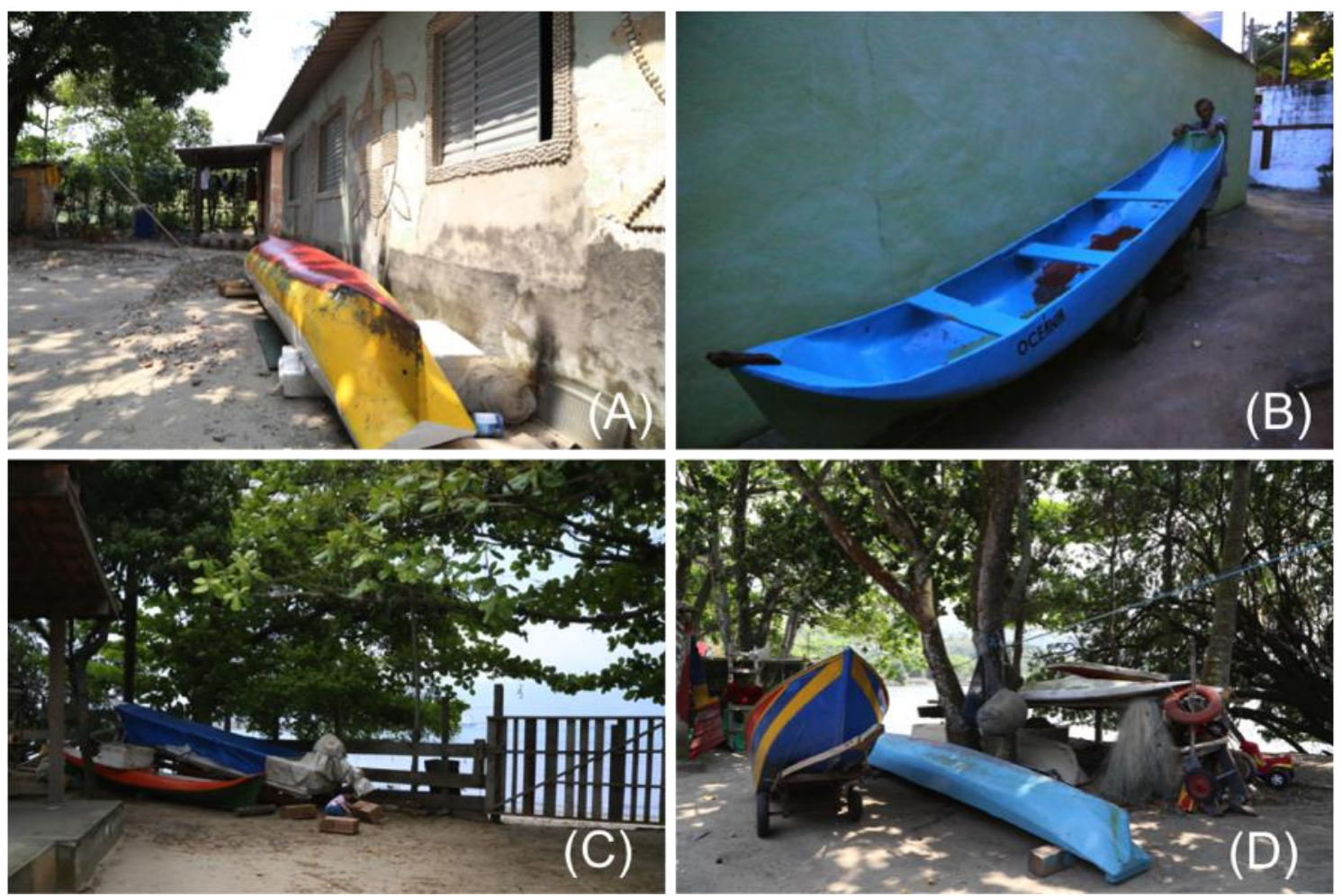

Figura 18: Canoas a remo $(A, B, C$ e $D)$ e pequenas lanchas $(C$ e $D)$ dos pescadores do Araçá, guardadas nos quintais de suas casas. Autor(a): (A, B, C e D) Fernanda T. Stori (São Sebastião, outubro de 2014).
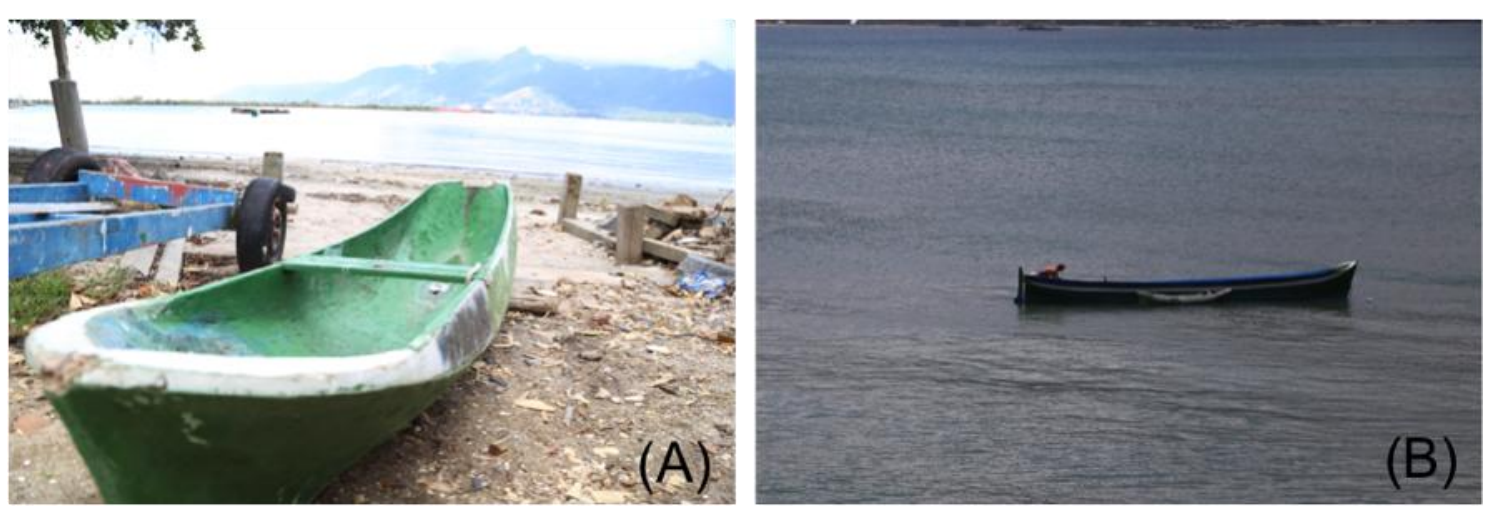

Figura 19: Canoas dos pescadores locais. A primeira $(A)$, localizada em uma das praias da baía, e a segunda (B), fundeada em uma área abrigada. Autor(a): (A, B) Fernanda T. Stori (São Sebastião, dezembro de 2014). 
Em relação a regularidade com que praticam a atividade pesqueira, a ampla maioria (15) declarou que costuma sair para pescar ao menos uma vez por semana, sendo que 5 indicaram realizar saídas diárias quando possível (Figura 20). Apenas 1 entrevistado (aposentado) afirmou que tem ido pescar "raramente" (até uma vez por mês): "última vez que fui pescar faz uns 20 dias atrás... Saio para pescar uma vez por mês ou uma vez a cada dois meses..." (Pescador 15, 61 anos). Para ele "a pesca diminuiu muito" sendo, atualmente, apenas uma atividade casual de lazer.

\section{Regularidade com que os entrevistados costumam pescar no Araçá}

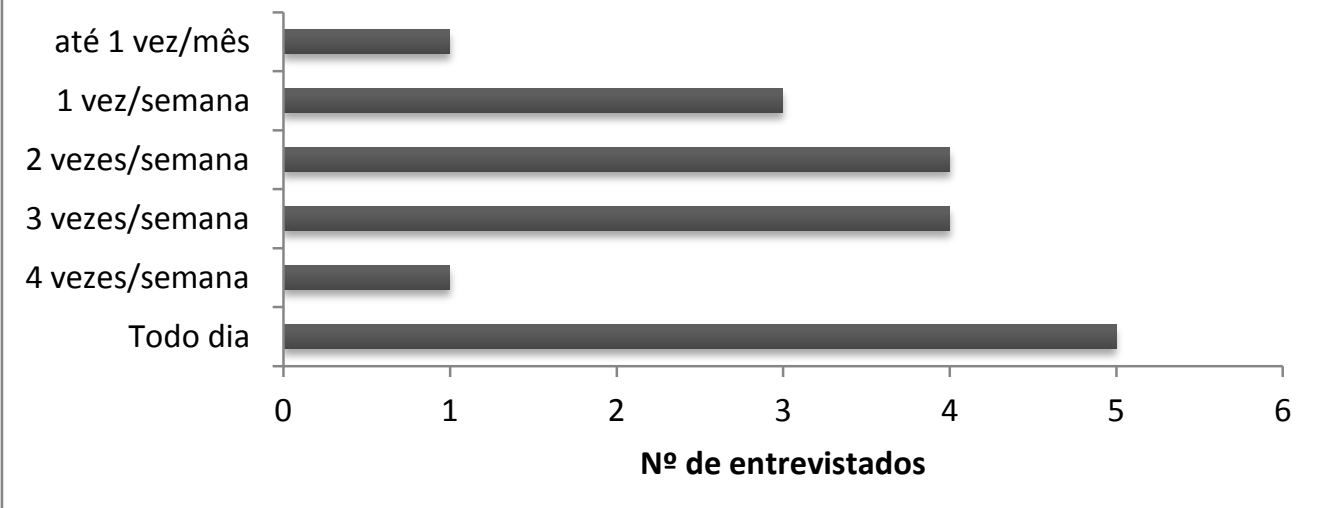

Figura 20: Distribuição dos entrevistados $(\mathrm{n}=18)$ segundo a regularidade aproximada com que costumam pescar no Araçá.

Segundo os próprios pescadores, essa regularidade (frequência) com que costumam pescar não depende apenas de sua vontade própria, mas também de uma série de condições como o tempo/clima, época do ano e condições do mar. Além disso, aqueles que tem um emprego ligado a outras atividades só podem pescar quando estão de folga. Já aqueles que tem a pesca como fonte de renda principal, costumam pescar praticamente todos os dias e, eventualmente, até mesmo quando as condições do mar e do tempo não são favoráveis.

Por causa do serviço só pesco quando vejo que tem condições e estou livre. (...) Quando a gente sabe que tá dando (peixe), que nem agora que é a época do carapau, agente vai mais. (Pescador 16, 62 anos)

Depende da natureza. Se o tempo está bom ou não. Se pudesse, todos os dias... (Pescador 3, 72 anos) 
No verão quase todo dia a gente sai. No inverno a gente quase não sai... (Pescador 7, 56 anos)

Vou todo dia! As vezes até com tempo ruim... (Pescador 12, 37 anos)

Ao serem questionados se existe algum tipo de regra de ordenamento pesqueiro entre os próprios pescadores do Araçá, a ampla maioria afirmou que não. Para os pescadores o mar é de todos e de livre acesso, mas existe o respeito, pautado no bom senso e na camaradagem, que ajuda a evitar possíveis conflitos na disputa por recursos:

Nunca houve e nunca haverá um limite de um e de outro pescar... O mar é de todos... (Pescador 15, 61 anos)

Aqui não tem essa... É tudo de livre acesso... (Pescador 13, 27 anos)

A regra é um respeitar o outro... Quem chega primeiro... Não pode jogar a rede em cima do outro... (Pescador 4, 30 anos)

Pelo número de pescadores que tem não tem regras... Se eu coloco uma rede, se você não é dono a única regra é não mexer... É o respeito... (Pescador 16, 62 anos)

Tem respeito... Se há uma pessoa pescando em um lugar eu não vou lá pescar também... (Pescador 18, 58 anos)

Tem assim, quando você larga um espinhel, vai outro lá e respeita né. Ele vê as boias e vai pra outro lugar. Ele não vai largar ali porque um vai atrapalhar o outro. Mas não tem rivalidade. Pelo contrário, é camaradagem, um ajuda o outro... (Pescador 3, 72 anos)

Além dessa política de respeito, alguns pescadores também ressaltaram a consciência de não capturar organismos juvenis e fêmeas que estejam em período reprodutivo. Outra questão que também foi mencionada, foi o uso de estratégias para guardar segredo e não revelar os locais onde tiveram sucesso em pescarias recentes.

A regra é a consciência de não pegar os animais ovados e os menores... (Pescador 8, 43 anos)

Eu procuro soltar os bichos pequenos e as fêmeas. Procuro só pegar os maiores para os menores poderem 
procriar depois... (pescador 12, 37 anos)

Se a gente mata uns peixes bons... A gente não fala onde foi... Mas o pessoal sabe onde são os pontos... (Pescador 13, 44 anos)

Ao refletir e lembrar de suas próprias memórias sobre como era a pesca "antigamente", todos os entrevistados concordaram que ocorreram mudanças nas últimas décadas. Para eles, a principal foi a diminuição da quantidade e da variedade de organismos capturados na região:

O que mais mudou foi a sardinha e o parati. Diminui muito a quantidade... (Pescador 7, 56 anos)

A pesca tornou-se mais difícil né... (Pescador 3, 72 anos)

Antigamente você saia 1 a 2 horas no canalzinho e matava 6 a $7 \mathrm{~kg}$ de corvina. Garoupa mesmo você também matava muita. Hoje você fica o dia inteiro pra pegar 3 a 4 corvinas... (Pescador 2, 60 anos)

Sumiram várias espécies daqui... Os robalos diminuíram, pescada, camarões... (Pescador 10, 45 anos)

Deixava (a rede) de tarde pra tirar de manhã cedo e vinha fartura... Hoje já não é a mesma fartura de antigamente...

Não existe mais peixe como tinha antes ali. Tinha muita enchova, cação, corvina, sardinha, tainha... (Pescador 13, 27 anos)

Dentre as causas mencionadas para tais mudanças (Tabela 3), foram citadas questões atuais, como a poluição por esgoto e o tráfego intenso de grandes embarcações, e questões pretéritas, como a construção de uma extensa área de aterro (nas décadas de 1970 e 1980), para dar lugar ao Porto de São Sebastião. Segundo os pescadores, nada foi feito para tentar reverter as mudanças que ocorreram a não ser o fato de que as pessoas da comunidade passaram a protestar, reclamar e cobrar com maior frequência 0 poder público por ações mais efetivas na região. 
Tabela 3: Principais causas responsáveis por mudanças na pesca, segundo a opinião dos pescadores entrevistados.

\begin{tabular}{|c|c|}
\hline $\begin{array}{l}\text { Causas das mudanças na } \\
\text { pesca }\end{array}$ & Trechos das entrevistas \\
\hline $\begin{array}{l}\text { Ampliação do porto nas } \\
\text { décadas de } 1970 \text { e } 1980 \\
\text { (dragagem e construção do } \\
\text { aterro) }\end{array}$ & $\begin{array}{l}\text { - "A ampliação do porto..." } \\
\text { - "A dragagem, o aterro que fizeram no porto..." } \\
\text { - "O maior motivo que eu acho ainda foi a construção } \\
\text { dessa barragem, desse aterrão do porto..." } \\
\text { - "Quando se constrói pra dentro do mar acaba tendo } \\
\text { alguma modificação. Então algumas espécies somem e } \\
\text { outras aparecem..." }\end{array}$ \\
\hline $\begin{array}{l}\text { Operação do porto atual } \\
\text { (movimento de } \\
\text { embarcações, barulho, } \\
\text { poluição, iluminação } \\
\text { noturna) }\end{array}$ & $\begin{array}{l}\text { - "Uma coisa que fez os peixes saírem foi o barulho. } \\
\text { Outra coisa foram aqueles refletores que colocaram (no } \\
\text { porto) virado pra praia e só assusta os peixes..." } \\
\text { - "Muita poluição e movimento de embarcação. O peixe } \\
\text { gosta de lugar mais tranquilo..." } \\
\text { - "Houve um aumento das embarcações e da } \\
\text { movimentação dos barcos. Como aqui é um lugar mais } \\
\text { parado acaba assustando os peixes... A movimentação } \\
\text { do próprio porto..." } \\
\text { - "O barulho... Máquinas que soltam óleo na praia..." }\end{array}$ \\
\hline $\begin{array}{l}\text { Petrobrás (acidentes e } \\
\text { vazamentos de óleo) }\end{array}$ & $\begin{array}{l}\text { - "Teve o derramamento de petróleo que houve há } \\
\text { alguns anos..." } \\
\text { - "Houveram vários derramamentos que eu vi... Atingiu } \\
\text { tudo..." }\end{array}$ \\
\hline $\begin{array}{l}\text { Construção do Emissário } \\
\text { Submarino do Araçá }\end{array}$ & $\begin{array}{l}\text { - "A Sabesp fez a canalização do esgoto, mas esse } \\
\text { emissário teria que ir mais pra fora... Do jeito que está } \\
\text { ele acaba com a balneabilidade..." }\end{array}$ \\
\hline $\begin{array}{l}\text { Pesca (aumento do esforço } \\
\text { pesqueiro e desrespeito a } \\
\text { legislação) }\end{array}$ & $\begin{array}{l}\text { - "É como te falei... Como tem bastante gente que pega } \\
\text { diminui a quantidade..." } \\
\text { - "Acho que não só aqui mas nos outros lugares é o } \\
\text { homem. Não respeitando as áreas de preservação, não } \\
\text { pegando os animais no tamanho certo, pegando os } \\
\text { menores..." }\end{array}$ \\
\hline $\begin{array}{l}\text { Perda/redução do } \\
\text { manguezal }\end{array}$ & $\begin{array}{l}\text { - "Acho também que é por causa do mangue que tá se } \\
\text { acabando..." }\end{array}$ \\
\hline $\begin{array}{l}\text { Crescimento urbano } \\
\text { desordenado e ausência do } \\
\text { poder público (ausência de } \\
\text { políticas de planejamento, } \\
\text { controle e gestão) }\end{array}$ & $\begin{array}{l}\text { - "O que causou foi o crescimento desordenado..." } \\
\text { - "Devido ao crescimento as coisas foram acabando, } \\
\text { aumentou a presença de lixo nos rios..." } \\
\text { - "O progresso sem controle e planejamento... Sem } \\
\text { estudos..." }\end{array}$ \\
\hline
\end{tabular}

Quando perguntados sobre o futuro da atividade pesqueira na Baía do Araçá, metade dos entrevistados (9) mencionaram ter uma grande preocupação com relação ao projeto de ampliação do Porto de São Sebastião e, para eles, a pesca pode "acabar por completo" no local, caso tal projeto seja realizado:

Se construir o cais (ampliação do porto) pode esquecer... (Pescador 2, 60 anos) 
Se fizerem o porto pode acabar com o espaço da gente. O espaço da gente pescar... (Pescador 7, 56 anos)

Não acho que vá acabar por completo. Mas pode diminuir ainda mais. $A$ não ser que o homem não mexa mais em nada... Mas hoje tem a discussão da ampliação do porto né... (Pescador 12, 37 anos)

Ao considerar essa possibilidade, de que no futuro a pesca pode acabar na Baía, alguns disseram que abandonariam tal atividade, enquanto outros mudariam suas áreas de pesca ou, então, mudariam sua residência para outra região. O sentimento de tristeza ao pensar nessa hipótese também foi evidente e ficou marcado nos depoimentos registrados, assim como apresentando nos exemplos abaixo:

Se acabasse... O que a gente tem aqui é isso, a pesca artesanal. Tem muita gente que mora aqui, que tem sua canoinha, que pesca um pouquinho... Tudo isso vai atrapalhar... Acaba... Pra pescar eu teria que alugar barco e sair daqui pra pescar fora... (Pescador 2, 60 anos)

As iscas que eu pego de parati não vai ter. Vou ter que buscar recursos em outro lugar... (Pescador 1, 49 anos)

Se a pesca acabasse eu ia pra fora... Pescar em outros lugares menos detonados... (Pescador 11, 44 anos)

Teria que aceitar né. Mas pra mim que já tenho idade avançada tudo bem. E meu netinho? Pra mim ainda é, vamos dizer, suportável. Vamos ficar triste né... Todo mundo que pensa como eu, não vai querer isso nunca... (Pescador 3, 72 anos)

Ficaria triste. Não poderia mostrar pro meu neto, apenas por fotografia... (Pescador 18, 58 anos)

Venderei minhas embarcações e acabou... (Pescador 14,58 anos)

Do ponto de vista do ordenamento pesqueiro, ao serem questionados se seriam a favor da criação de áreas fechadas para pesca na região da Baía do Araçá, 13 pescadores afirmaram que não. Para eles, o ambiente local é capaz de suprir e sustentar a pesca artesanal sem comprometer a continuidade da atividade na região e gerar impactos negativos significativos sobre a biota 
marinha, pelo fato ser realizada em pequena escala. Como alternativas para assegurar o uso racional dos recursos pesqueiros no Araçá, os pescadores sugeriram manter as políticas de defeso; regulamentar a pesca por artes de pesca e proibir o uso do arrastão; proibir a pesca por "atuneiros" e barcos de maior porte, e aumentar a fiscalização, conforme exposto nos trechos de depoimentos a seguir:

Não, porque controla né. Aqui a criação é uma grandeza... O que não pode é os atuneiros né. Porque eles precisam de isca e eles vem pegar aqui... (Pescador 3, 72 anos)

Não... Acho que se não mexer já é show. Acho que só teria que ter o controle do arrastão no verão... Mas ninguém fiscaliza... Porque pra peixe não tem tantos pescadores e o que tem suporta... (Pescador 8, 43 anos)

Não precisa, pode manter porque não altera, porque é artesanal, não dá aquele impacto que estraga, como o arrastão. Deveria haver regulamentação pela arte de pesca... Pesca artesanal quase não estraga, mas barco grande sim... (Pescador 14, 58 anos)

Não precisa... O que já tem que é muito importante são os defesos... Ali sem ser de forma artesanal você não tem como entrar... Então não tem pesca industrial.... Os peixes criam e vão pra fora então não tem problema... (Pescador 16, 62 anos)

Não, precisava de mais limites e fiscalização... (Pescador 18, 58 anos)

Apenas cinco pescadores foram a favor da criação de áreas de restrição da atividade pesqueira. Entretanto, desses, somente dois afirmaram que tal restrição deveria ser total e permanente. Os demais sugeriram uma restrição parcial, para algumas espécies mais ameaçadas e artes de pesca mais predatórias, ou apenas por um determinado período de tempo, de forma similar ao defeso.

Se fosse pra criar tipo um santuário seria aqui... Todinha da ponta do Araçá até o Farol do Moleque (área de costeira). Porque ali dá todas as espécies... Fecharia 150m da 
costeira pra fora. Pra não poder pescar dentro dessa faixa. Teria que fechar bastante tempo. Uns 6 meses. Que nem quando faz pra sardinha e pro camarão...(Pescador 2, 60 anos)

Limitaria o tipo de pesca. Para o arrastão, por exemplo, que mata muito peixe pequeno... (Pescador 12, 37 anos)

Fecharia aqui tudo (área interna da baía) desde a barra pra procriação... Pros peixes poderem procriar aqui dentro. Mas não adianta fechar tudo... Eu não tiraria o berbigão e o camarão que eles pegam pra isca... Mas pra comercial não. Passando um tempo os peixes daqui vão migrar pra outros lugares também... (Pescador 4, 30 anos)

"Sim. Se pudesse eu fechava tudo aqui (em referência ao interior da baía). Só pescaria pra fora... Porque é bonito sabe... Deveria preservar isso aqui. Eu deixaria pra sempre porque o peixe procria aqui e depois vai pra fora, então a gente pesca ele lá fora..." (Pescador 11, 44 anos) 


\section{O CONHECIMENTO ETNOOCEANOGRÁFICO DOS PESCADORES DO}

ARAÇÁ

\section{A biodiversidade - etnoespécies da fauna aquática do Araçá}

A elevada biodiversidade sustentada pelo ecossistema costeiro-marinho da Baía do Araçá foi uma questão amplamente citada e reconhecida pelos pescadores entrevistados, conforme exemplificado a seguir:

A importância disso aqui (do Araçá) é grandiosa né... A princípio é a biodiversidade que tem de peixes, de crustáceos... (Pescador 13, 27 anos)

Isso para nós é um santuário... Aí tem tudo quanto é espécie... (Pescador 14, 58 anos)

$A$ vida que tem aqui você não acha em nenhum outro lugar nessa área nossa aqui do litoral norte. Até filhote de mero você encontra nas beiras de pedras aí... (Pescador 11, 44 anos)

Considerando apenas a fauna aquática, ao todo, foram mencionadas 53 etnoespécies que podem ser encontradas no território pesqueiro do Araçá (Tabela 4). Dessas, 39 são peixes, 13 são invertebrados (3 moluscos e 10 crustáceos) e um é réptil. Para todas as etnoespécies citadas, classificadas segundo a nomenclatura própria dos pescadores, foram identificadas os prováveis grupos taxonômicos (no menor nível possível) equivalentes na linguagem científica. 
Tabela 4: Etnoespécies da fauna aquática encontradas no território pesqueiro do Araçá e citadas pelos pescadores entrevistados.

\begin{tabular}{|c|c|c|}
\hline ETI & VOESPÉCIES & TÁXONS (prováveis/possíveis) \\
\hline Peiz & xes & \\
\hline 1 & Anchova & Pomatomus saltatrix \\
\hline 2 & Badejo ou Miracelo & Mycteroperca acutirostris \\
\hline 3 & Baiacú & $\begin{array}{l}\text { Chliomucterus spinosus, Lagocephalus laevigatus, } \\
\text { Sphoeroides greeleyi, Sphoeroides spengleri, } \\
\text { Spheoroides testudineus }\end{array}$ \\
\hline 4 & Betara ou Papa-terra & Menticirrhus americanus \\
\hline 5 & Budião & Nicholsina usta \\
\hline 6 & $\begin{array}{l}\text { Cação-viola ou Raia- } \\
\text { viola }\end{array}$ & Rhinobatos parcellens \\
\hline 7 & Canhanha ou Salema & Anisotremus virginicus, Archosargus rhomboidalis \\
\hline 8 & Carapau & Chloroscombrus chrysurus \\
\hline 9 & Carapeba & Diapterus rhombeus \\
\hline 10 & Carapicu & $\begin{array}{l}\text { Eucinostomus argenteus, Eucinostomus gula, } \\
\text { Eucinostomus melanopterus }\end{array}$ \\
\hline 11 & Caratinga & Eugerres brasilianus \\
\hline 12 & Corcoroca & Haemulon steindachneri, Haemulopsis corvinaeformis \\
\hline 13 & Corvina & Micropogonais furnieri \\
\hline 14 & Espada & Trichiurus lepturus \\
\hline 15 & Galo & Selene vomer \\
\hline 16 & Garoupa & Epinephelus marginatus \\
\hline 17 & $\begin{array}{l}\text { Guaiú, Tanaguaiú ou } \\
\text { Peixe-agulha }\end{array}$ & $\begin{array}{l}\text { Hemiramphus brasiliensis, Hyporhamphus roberti, } \\
\text { Hyporhamphus unifasciatus, Strongylura marina, } \\
\text { Strongylura timicu }\end{array}$ \\
\hline 18 & Guaivira & Oligoplites saliens \\
\hline 19 & Linguado & $\begin{array}{l}\text { Syacium papillosum, Symphurus tessellatus, Etropus } \\
\text { longimanus, Etropus crossotus, Citharichthys } \\
\text { arenaceus, Citharichthys macrops, Citharichthys } \\
\text { spilopterus }\end{array}$ \\
\hline 20 & Manjuba & $\begin{array}{l}\text { Anchoa lyolepis, Anchoa tricolor, Anchovia clupeoides, } \\
\text { Anchoviella lepidentostole, Lycengrauslis grossidens }\end{array}$ \\
\hline 21 & Maria-luiza & Paralonchurus brasiliensis \\
\hline 22 & Marimbá ou Sargo & Diplodus argenteus, Anisotremus surinamensis \\
\hline 23 & Mero & Epinephelus itajara \\
\hline 24 & Moreia & Myrophis puncatus; Gymnothorax ocellatus \\
\hline 25 & Parati & $\begin{array}{l}\text { Mugil curema, Mugil hospes, Mugil incilis, Polydactylus } \\
\text { virginicus }\end{array}$ \\
\hline 26 & Pampo & Trachinotus carolinus, Trachinotus goodei \\
\hline 27 & Paru ou Peixe-frade & Pomacanthus paru \\
\hline 28 & Pescada & $\begin{array}{l}\text { Ctenosciaena gracilicirrhus, Cynoscion leiarchus, } \\
\text { Odontoscion dentex }\end{array}$ \\
\hline 29 & Pirajica & Kyphosus incisor, Kyphosus sectatrix \\
\hline 30 & Porquinho & Stephanolepis hispidus \\
\hline 31 & Prejereba & Lobotes surinamensis \\
\hline 32 & Robalo & Centropomus parallelus, Centropomus undecimalis \\
\hline 33 & Sardinha & $\begin{array}{l}\text { Sardinella brasiliensis, Opisthonema oglinum, Pellona } \\
\text { harroweri, Herengula clupeola, Anchovia clupeoides }\end{array}$ \\
\hline
\end{tabular}


Tabela 4 (continuação): Etnoespécies da fauna aquática encontradas no

território pesqueiro do Araçá e citadas pelos pescadores entrevistados.

\begin{tabular}{|l|l|l|}
\hline 34 & Sargo & Diplodus sargus \\
\hline 35 & Sororoca & Scomberomous brasiliensis \\
\hline 36 & Tainha & Mugil liza \\
\hline 37 & Vermelho & Lutjanus analis, Lutjanus synagris \\
\hline 38 & Xarelete & Caranx latus \\
\hline 39 & Xaréu & Caranx hippos \\
\hline Répteis & Chelonia mydas \\
\hline 40 & Tartaruga & Anomalocardia brasiliana \\
\hline \multicolumn{3}{|l|}{ Moluscos } \\
\hline 41 & Berbigão & Trachycardium muricatum \\
\hline 42 & Mija-mija & Cephalopoda (Classe) - Octopoda (ordem) \\
\hline 43 & Polvo & Litopenaeus schmitti \\
\hline Crustáceos & Artemesia longinaris \\
\hline 44 & Camarão branco & Xiphopenaeus kroyeri \\
\hline 45 & Camarão ferrinho & Ucides cordatus \\
\hline 46 & Camarão-sete-barbas & Menippe nodifrons \\
\hline 47 & Caranguejo-uçá & Cardisoma guanhumi \\
\hline 48 & Guaiá & Maja squinado \\
\hline 49 & Guaiamum & Callinectes sapidus; Callinectes danae \\
\hline 50 & Santola & Portunus spinimanus \\
\hline 51 & Siri-azul & Stomatopoda (gênero) \\
\hline 52 & Siri-candeia &
\end{tabular}

Além de reconhecer a elevada biodiversidade que o território pesqueiro do Araçá sustenta, os pescadores entrevistados também destacaram a importância do local para a reprodução e desenvolvimento das fases iniciais de vida de diversas espécies da fauna marinha. Neste contexto, os pescadores citaram diversas etnoespécies (Tabela 5) como o camarão ferrinho, o parati e a tainha, que usam principalmente a área interna da baía como um local de reprodução, viveiro, criadouro, berçário. Para eles, essa região (área interna da Baía do Araçá) é propícia para a reprodução dessas espécies por diversos motivos como, por exemplo: o fato de ser um "remanso", onde as águas são rasas, calmas e mais quentes; a proteção contra predadores maiores, que tem dificuldade em atingir essas áreas mais rasas; a ampla disponibilidade de alimentos, dos mais variados tipos; e os diferentes habitats, como o as áreas de fundo de arenoso/lamoso e de manguezais, dos quais certas espécies "gostam". Nos trechos das entrevistas transcritos a seguir, tais questões podem ser evidenciadas:

Enxergo (o Araçá) como um lugar de reprodução de 
espécies em todos os sentidos. (...) Um habitat natural que nós temos... (Pescador 16, 62 anos)

Isso aqui é um berçário... São vários animais que se reproduzem no Araçá e que fazem migração...(...) Acho que eles (camarão ferrinho) vem desovar aqui. Muitos vão embora e uma parte fica. Acho que por causa do remanso, calmaria e a lama também. Eles ficam enterrados na lama e no limo também... Nessas algas... (Pescador 8, 43 anos)

Tem gente que fala que acabou mas tem peixe ainda. $E$ eles se criam bem aqui nessa Baía do Araçá. É criadouro, é celeiro. A proliferação deles aqui é uma grandeza... (...) Aqui é o local que eles (peixes) desovam né. Eles criam aí e depois vão pra outros lugares. Aqui é mais manso também, outros locais é mais bravo. A praia de guaecá é bravo, a praia de maresias é bravíssima... Então os que habitam lá não habitam aqui, os que habitam aqui habitam porque é manso... É abrigo... (Pescador 3, 72 anos)

Eles (camarão ferrinho) gostam de lama pra procriar... Aqui é onde o solo é mais mole então é onde eles se abrigam mais... (Pescador 11, 44 anos)

Aqui é um remanso e um criador de siri, camarão, parati... Por ser uma bacia, de águas calmas... Eles querem ficar em um lugar tranquilo... (Pescador 1, 49 anos)

Nessa área você tem o camarão, os paratis pequeninos... Aqui tem a desova. Por ser mais raso os peixes maiores não conseguem vir... É mais seguro pra eles por causa dos predadores maiores... (Pescador 16, 62 anos)

O parati e a tainha são parecidos... A fêmea desova na boca de rio, então ela desova e procria aqui... Aqui tem muito limo né e eles comem limo... Aí só depois que tem um certo tamanho que vão procurar mar aberto... (Pescador 9, 41 anos)

Elas (a tainha e o parati) gostam da lama e por causa da água ser quente também, porque elas vem pra cá pra desovar. Elas gostam da água quente pra desovar... (Pescador 4,30 anos)

Ali onde tem o mangue eles (peixes) entram 
principalmente na maré de sizígia, quando fica tudo isso aqui alagado... Dali a 5 a 6 dias os ovos já começam a eclodir... E é justamente um ciclo... O tempo dele desovar com o tempo das marés. Então eu acho que toda a área do mangue é importante... Desde lá de dentro da gamboa do mangue, até aqui pra cá... (Pescador 9, 41 anos)

Tabela 5: Etnoespécies que, segundo os pescadores, usam a área interna da

Baía do Araçá como um local de reprodução e desenvolvimento nas fases iniciais de vida ("berçário").

\begin{tabular}{|l|l|}
\hline \multicolumn{1}{|c|}{$\begin{array}{c}\text { Etnoespécies que usam a área interna da baía como } \\
\text { um local de reprodução/desenvolvimento }\end{array}$} \\
\hline Peixes & Moluscos \\
\hline Badejo & Berbigão \\
\hline Betara & Mija-mija \\
\hline Canhanha (ou Salema) & Polvo \\
\hline Carapeba & Crustáceos \\
\hline Carapicu & Camarão branco \\
\hline Caratinga & Camarão ferrinho \\
\hline Corcoroca & Caranguejo-uçá \\
\hline Corvina & Guaiá \\
\hline Guaiú & Santola \\
\hline Parati & Siri-azul \\
\hline Sardinha & Siri-candeia \\
\hline Tainha & Tamburutaca \\
\hline
\end{tabular}

Espécies como a tartaruga, a raia-viola e o mero foram as únicas citadas que não são capturadas pelos pescadores do Araçá, por serem reconhecidas enquanto espécies protegidas. Sua captura ocorre apenas acidentalmente e, quando os animais são encontrados vivos, os pescadores declaram que fazem sua soltura:

Que cria aí na lama também de vez em quando mas quando a gente acha a gente solta é cação (raia) viola. Nessa parte aqui da areia... Tartaruga tem bastante também... (Pescador 4, 30 anos)

Dentre as demais etnoespécies mencionadas pelos pescadores entrevistados, 22 (16 peixes e 6 invertebrados) foram citadas por pelo menos 3 pescadores como sendo as principais espécies alvo e as mais capturadas em suas pescarias (Figura 21). 


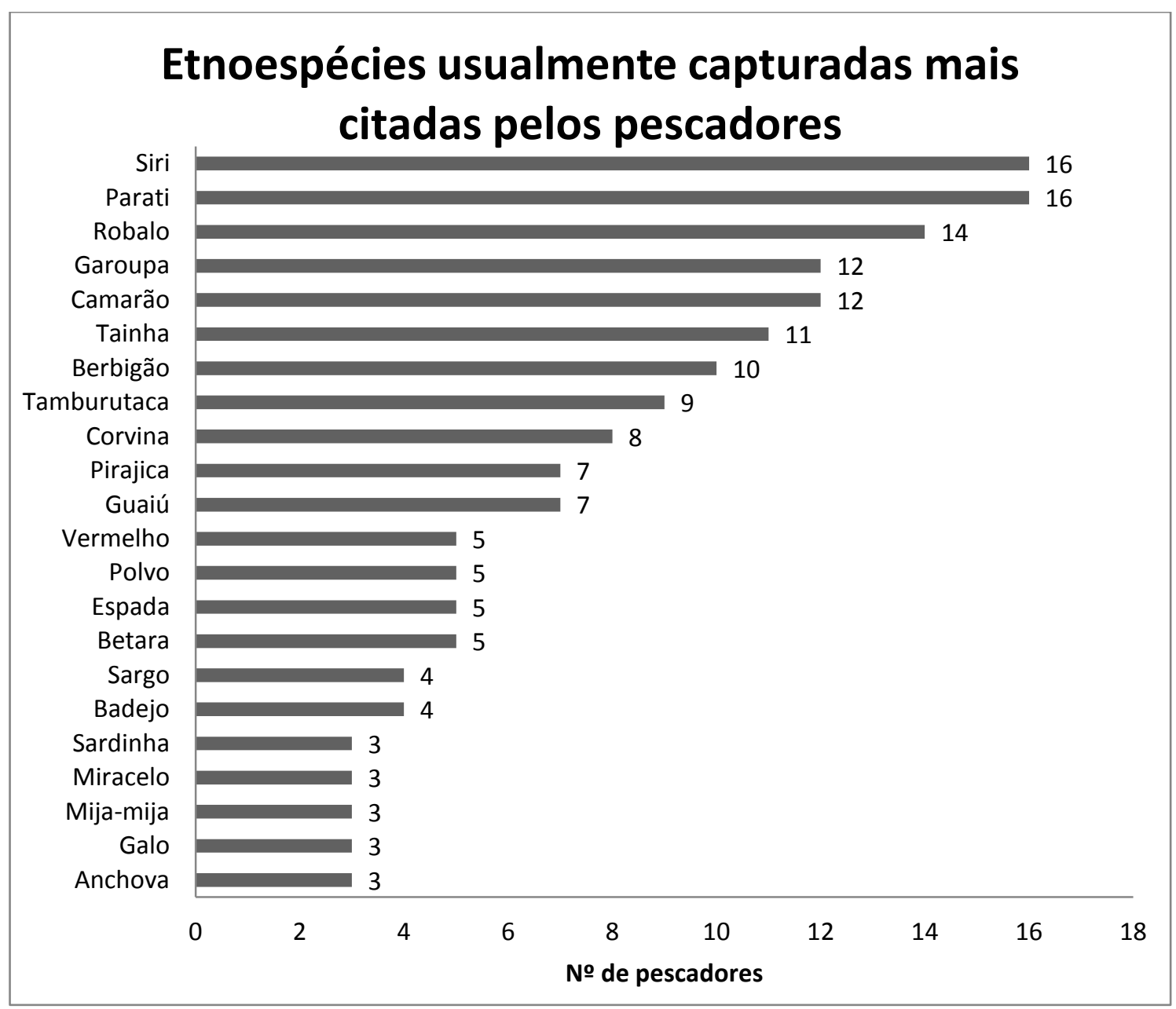

Figura 21: Principais etnoespécies alvo capturadas no território pesqueiro dos pescadores do Araçá.

Todas as espécies, com exceção do camarão ferrinho (que é próprio para ser usado como isca), são utilizadas para consumo e muitas possuem alto valor comercial como, por exemplo, o robalo, o vermelho, a garoupa e o badejo. Além do camarão ferrinho, peixes de baixo valor comercial que são abundantes na região, como o parati e o guaiú, também são muito utilizados como isca para a captura de espécies com maior valor de mercado, conforme apresentado nas seguintes falas:

Aqui no mangue do Araçá uma das principais pescarias é o camarão (ferrinho) vivo, que é a principal isca para o robalo e para o badejo, que são os peixes nobres, que é caro... Só onde a gente consegue a isca é aqui... (Pescador 3, 72 anos)

No Araçá eu pego isca de parati para poder sair pra pegar garoupa, que eu pesco no canal aqui, que eu pesco com o espinhel. Sem isso eu não consigo pegar outros peixes que 
eu pego aqui na frente, no canal... (Pescador 1, 49 anos)

Com as iscas que já peguei aqui eu vou pegar garoupa, robalo, pirajica... Esses eu vou pescar aqui na frente que é onde tem os parcéis... (Pescador 16, 62 anos)

Os pescadores entrevistados reconhecem dois períodos sazonais diferentes ao longo do ano: verão (de outubro a março) e inverno (de abril a setembro). Etnoespécies como garoupa, robalo, sardinha, camarão ferrinho e camarão sete-barbas foram apontadas como mais abundantes no território pesqueiro do Araçá durante o verão. Já a tainha e a corvina foram indicadas como mais abundantes no inverno. As demais, ou foram citadas como espécies que ocorrem o ano todo (casos do parati, pirajica e berbigão), ou não possuem um padrão de sazonalidade bem definido e foram citadas por alguns pescadores como mais abundantes no verão, e por outros, como mais abundantes no inverno (casos da sardinha e corvina). Tais características puderam ser evidenciadas em diversos trechos das entrevistas, como nos exemplos transcritos abaixo:

A tainha é mais no frio, no inverno, a época que ela entra... E tem algumas marisqueiras que a gente fala, que criam aqui mesmo... Essas tem o ano todo mas em menor quantidade... (Pescador 8, 43 anos)

A tainha é mais em junho, julho, quando é na época do frio... Já a maioria dos peixes começa agora em meados de outubro até fevereiro... Continuando fevereiro ainda pega mas a melhor época é essa. Pra todos os peixes, menos a tainha né... (Pescador 3, 72 anos)

O Parati dá o ano todo, mas de outubro até fevereiro ele está no tamanho ideal que eu pego... (Pescador 1, 49 anos)

Garoupa, sargo, miracelo é tudo peixe de época quente... Eles gostam de água quente então é melhor no verão... (Pescador 14, 58 anos)

O camarão dá mais nessa época do verão... É o camarão ferrinho que agente chama né... Você pega no resto do ano também, mas dá mais é agora (no verão)... (Pescador 13, 27 anos) 
Aspectos comportamentais e a preferência de algumas etnoespécies (sobretudo as mais visadas durante as pescarias) por certos habitats também são questões de grande conhecimento dos pescadores no território pesqueiro do Araçá. Com o auxílio dos mapas falados, foram identificados cinco padrões entre as principais espécies de peixes capturadas: i) peixes de superfície ou de flor d'água, que percorrem a área interna da baía em busca de abrigo, alimentos e proteção contra predadores; ii) peixes de fundo arenoso/lamoso, que gostam de mariscar (se alimentar) junto ao fundo; iii) peixes de passagem, que são de fora e se aproximam da baía (principalmente pela laterais) em busca de presas; iv) peixes de costeira (predadores), que preferem os ambientes de costão rochoso para captura de presas; e v) peixes de parcel ou de fundo de pedra, que ficam em áreas profundas nas adjacências do Canal de São Sebastião (Tabela 6, Figura 22). 
Tabela 6: Padrões de comportamento e de ocupação dos habitats (zonas ecológicas) das principais etnoespécies de peixes capturadas no Araçá.

\begin{tabular}{|c|c|c|}
\hline $\begin{array}{l}\text { Hábitos e habitats } \\
\text { preferenciais }\end{array}$ & $\begin{array}{l}\text { Etnoes- } \\
\text { pécies }\end{array}$ & Trechos das entrevistas \\
\hline $\begin{array}{l}\text { i) Peixes de } \\
\text { superfície ou de flor } \\
\text { d'água (geralmente } \\
\text { menores) que } \\
\text { circulam pelas } \\
\text { áreas rasas da baía } \\
\text { procurando abrigo, } \\
\text { alimentos e } \\
\text { proteção contra } \\
\text { predadores }\end{array}$ & $\begin{array}{l}\text { Sardinha } \\
\text { Guaiú } \\
\text { Parati } \\
\text { Tainha }\end{array}$ & $\begin{array}{l}\text { - "Além de ser o local de desova elas vem por causa da } \\
\text { tranquilidade, alimento, proteção... É uma área rasa..." } \\
\text { - "Acho que aqui é mais por ser um lugar de descanso... } \\
\text { Eles (peixes menores) saem da corrente do canal e vem } \\
\text { se abrigar aqui..." } \\
\text { - "Ficam na flor d'água né.. Eles gostam de água rasa... } \\
\text { Vem se alimentar..." } \\
\text { - "A tainha e o parati gostam de mariscar ou na lama eu } \\
\text { em beira de pedra, mas são mais de superfície... Vem } \\
\text { se alimentar..." } \\
\text { - "Justamente porque é um sistema de defesa... Quando } \\
\text { os cardumes de peixes menores (manjuba, sardinha, } \\
\text { guaiú e parati) encostam, quem direciona são os peixes } \\
\text { que vem batendo (robalo, espada, pirajica)... É uma } \\
\text { situacão de defesa..." }\end{array}$ \\
\hline $\begin{array}{l}\text { ii) Peixes de fundo } \\
\text { de areia e lama } \\
\text { (vem mariscar no } \\
\text { fundo) que também } \\
\text { circulam pela baía }\end{array}$ & $\begin{array}{l}\text { Betara } \\
\text { Corvina }\end{array}$ & $\begin{array}{l}\text { - "A corvina e a betara são peixes de fundo..." } \\
\text { - "São peixes de fundo, de lama... Acho que a } \\
\text { alimentação deve estar ali..." } \\
\text { - "É peixe de fundo de lama... Por ser calmo se } \\
\text { adentram mais aqui..." } \\
\text { - "Elas são marisqueiras né, são peixes de fundo... } \\
\text { Então acho que eles ficam lá comendo, mariscando..." }\end{array}$ \\
\hline $\begin{array}{l}\text { iii) Peixes de } \\
\text { passagem que vem } \\
\text { de fora atrás de } \\
\text { presas, se } \\
\text { aproximando } \\
\text { principalmente } \\
\text { pelas costeiras }\end{array}$ & $\begin{array}{l}\text { Anchova } \\
\text { Carapau } \\
\text { Espada } \\
\text { Sororoca }\end{array}$ & $\begin{array}{l}\text { - "Tem peixes que a gente fala que são peixes de } \\
\text { passagem que nem anchova, sororoca, espada... São } \\
\text { de fora... Eles vem atrás da manjuba, da sardinha, do } \\
\text { camarão..." } \\
\text { - "A sororoca segue a aproximação da sardinha da } \\
\text { costa... Ela é predador, assim como a anchova e o } \\
\text { carapau..." } \\
\text { - "Espada é um peixe de passagem. Eles encostam ali } \\
\text { para se alimentar... Eles entram por essas beiradas... } \\
\text { Ele não vem criar no estuário..." }\end{array}$ \\
\hline $\begin{array}{l}\text { iv) Peixes de } \\
\text { costeira (costões } \\
\text { rochosos) mas que } \\
\text { também entram na } \\
\text { baía atrás de } \\
\text { cardumes de } \\
\text { presas }\end{array}$ & $\begin{array}{l}\text { Galo } \\
\text { Pirajica } \\
\text { Robalo } \\
\text { Verme- } \\
\text { Iho }\end{array}$ & $\begin{array}{l}\text { - "A pirajica é mais de costeira... Assim como o robalo..." } \\
\text { - "Eles aparecem em toda costeira, em pedras..." } \\
\text { - "Robalo tem mais nessa parte da barrinha, nessa } \\
\text { entrada... Perto da Ponta do Araçá..." } \\
\text { - "Vem atrás do camarão e entram por essa ponta..." } \\
\text { - "Ficam mais na superfície. Você tem que localizar o } \\
\text { cardume de manjuba porque eles vem atrás..." } \\
\text { - "O robalo e a pirajica são peixes de ataque... Então } \\
\text { você tem que ficar em lugar que tem passagem de } \\
\text { peixe que é bico de pedra né..." }\end{array}$ \\
\hline $\begin{array}{l}\text { v) Peixes de parcel } \\
\text { ou de fundo de } \\
\text { pedra, que gostam } \\
\text { de fundos rochosos }\end{array}$ & $\begin{array}{l}\text { Badejo } \\
\text { Garoupa } \\
\text { Miracelo } \\
\text { Sargo }\end{array}$ & $\begin{array}{l}\text { - "O badejo, a garoupa, são peixes que gostam de fundo } \\
\text { de pedra, de parcéis..." } \\
\text { - "É peixe de toca, de pedra..." } \\
\text { - "O parcel é onde ficam os corais... É onde eles se } \\
\text { alimentam..." } \\
\text { - "Ficam em pedra, parcéis... É onde tem alimentação } \\
\text { pra eles em abundância. São marisqueiros..." }\end{array}$ \\
\hline
\end{tabular}




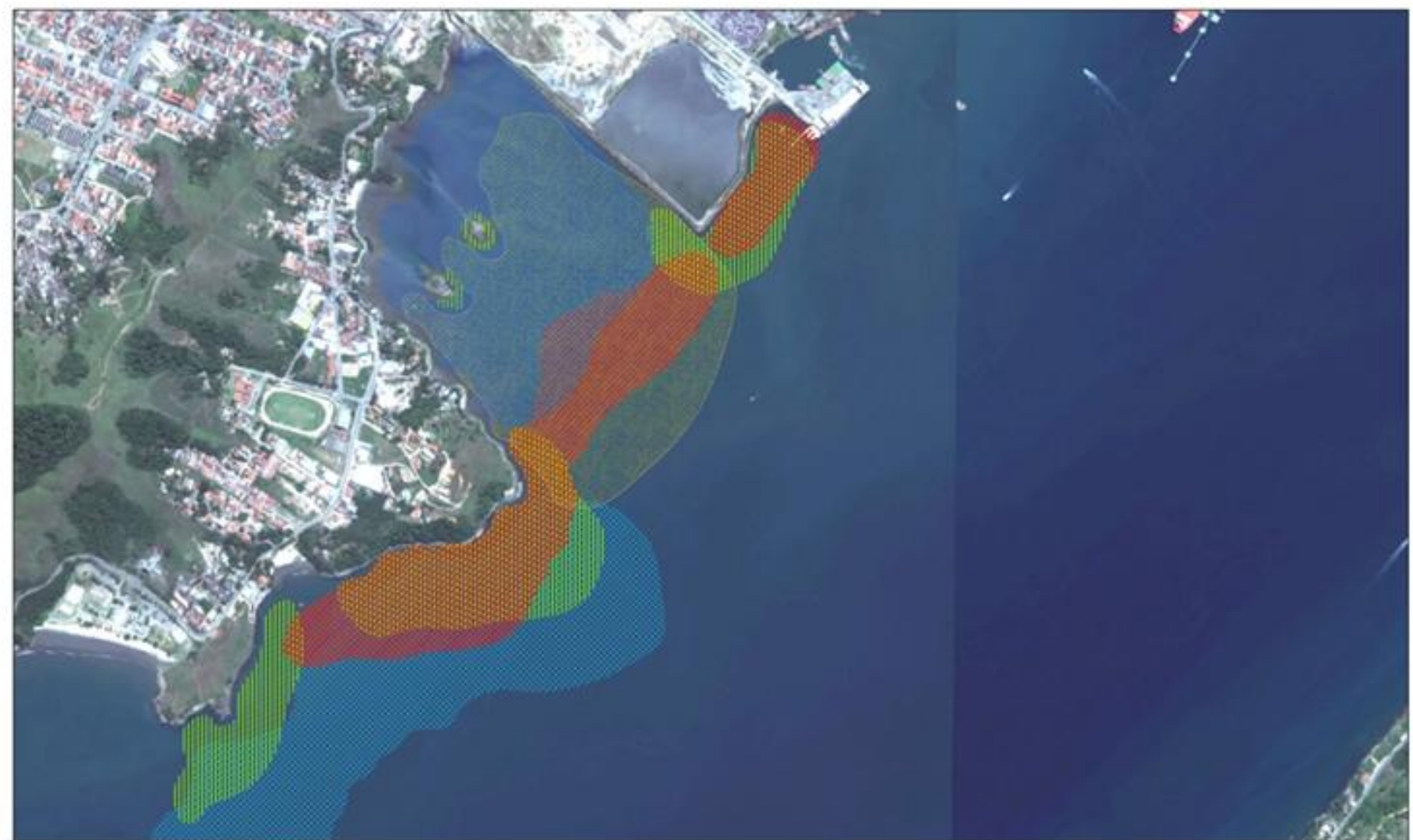

\section{Legenda}

i) Peixes de superfície ou de flor d'água

ii) Peixes de fundo arenosolamoso
ii) Peixes de passagem
iv) Peixes de costeira
v) Peixes de parcel ou de fundo de pedra

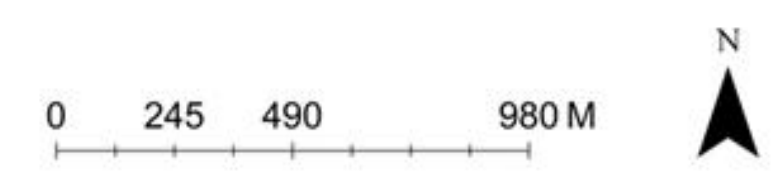

Figura 22: Padrões preferenciais de ocupação dos habitats (zonas ecológicas) pelos peixes capturadas no território pesqueiro do Araçá. 
Outro aspecto que foi revelado, é o comportamento de predação de peixes como espada, anchova e sororoca que "entram por essas beiradas" e "vêm atrás da sardinha, do camarão", ou como o robalo, pirajica e badejo que são "peixes de ataque" que ficam "escondidos". Assim, enquanto alguns predadores ficam esperando a passagem dos cardumes de peixes menores junto as costeiras (como nas proximidades da Ponta do Araçá), outros seguem esses cardumes pela costeira da baía adentro, onde tentam capturar suas presas (Figura 23). Segundo os pescadores, esse comportamento ocorre principalmente com a maré cheia, quando peixes menores (p.ex.: sardinha, manjuba, guaiú e paratis pequenos) entram na baía buscando abrigo e alimentos:

Os peixes ocorrem em toda baía, principalmente na maré-cheia... Os predadores entram para atacar cardumes de peixes pequenos. Então quando tá a maré-cheia que entra sardinha, manjuba, eles (robalos, espadas, entre outros) vem atrás... Eles entram sempre pela costeira, nunca entram pelo meio... Eles vão seguindo pelas laterais até chegar no mangue... Eles aproveitam o fluxo de água... (Pescador 9, 41 anos)

Robalo, pirajica, badejo, é tudo peixe de ataque. Ficam em lugar que tem passagem de peixe que é bico de pedra né... Esperam o peixe sair e já fica escondido pra pegar... Eles são atraídos devido ao camarão, parati pequeno, que são os alimentos dele... A tardezinha também entra manjuba pra descansar então eles ficam esperando... (Pescador 4, 30 anos) 


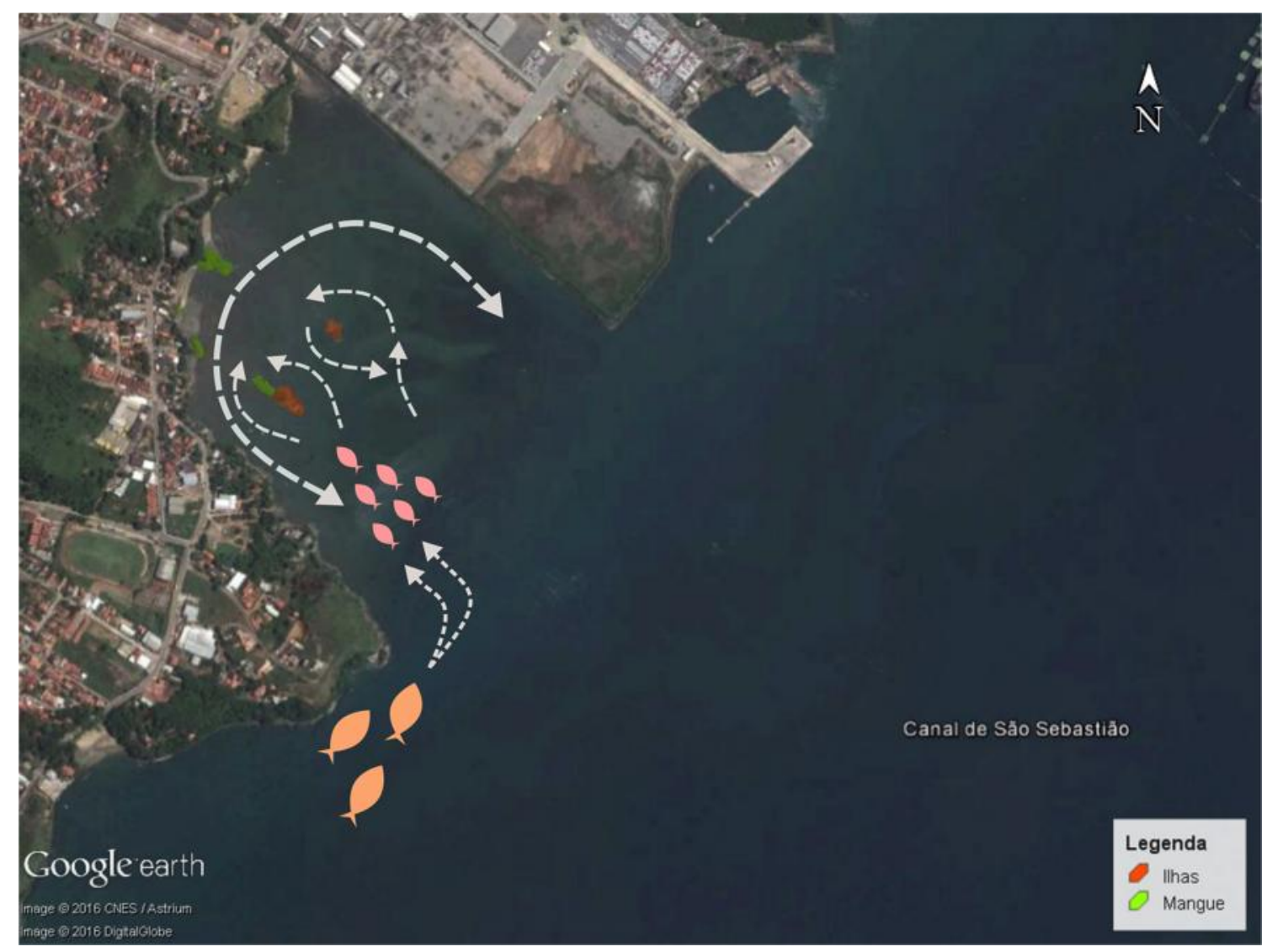

Figura 23: Representação das estratégias de predação de algumas etnoespécies de peixes a partir das representações descritas pelos pescadores: peixes menores circulam pela baía (trajetos simbolizados por flechas) durante a maré alta, enquanto os predadores (maiores) os seguem ou aguardam sua passagem próximo a Ponta do Araçá.

Para os principais invertebrados capturados pelos pescadores do Araçá também foi possível determinar os habitats de ocorrência e de maior abundância das seis principais etnoespécies capturadas também são bem conhecidas pelos pescadores (Tabela 7, Figura 24), de forma similar aos peixes. Fatores como a disponibilidade de alimentos e, principalmente, o "tipo de fundo" que cada espécie de invertebrado "gosta" (p.ex.: pedra, cascalho, areia, lama), foram as principais informações consideradas pelos pescadores para identificar esses padrões.. Segundo eles, esses invertebrados ocorrem principalmente, em áreas rasas no interior da baía (locais de fundo arenoso/lamoso) e ao redor das ilhotas e das costeiras (áreas rochosas ou áreas onde o fundo de cascalho):

Essas ilhas aqui tem muito guaiá, siri-candeia, polvo, mija-mija... (Pescador 11, 44 anos)

Essa área aqui toda (área rasa entre as ilhotas e a linha de costa)... Aqui tudo é siri (siri-azul) e berbigão também... 
(Pescador 4, 30 anos)

O camarão fica mais pra cá (área mais rasa)... Eles vêm e desovam aqui, aí, lá naquela lama... Ai conforme eles vão crescendo eles espalham tudo...(...) Aqui (nas ilhotas) tem 0 mija-mija... Perto do costão também tem... E ali vai polvo pra comer os mijas-mijas... (Pescador 8, 43 anos) 
Tabela 7: Habitats preferenciais das principais etnoespécies de invertebrados capturadas pelos pescadores no Araçá.

\begin{tabular}{|c|c|c|}
\hline Habitats & Etnoesp. & Trechos das entrevistas \\
\hline \multirow[t]{3}{*}{$\begin{array}{l}\text { Áreas } \\
\text { rasas de } \\
\text { fundo } \\
\text { arenoso- } \\
\text { lamoso } \\
\text { (próximo } \\
\text { das } \\
\text { ilhotas) }\end{array}$} & Berbigão & $\begin{array}{l}\text { - "Berbigão tem muito também. Do lado dessa ilhinha aqui, onde } \\
\text { que tem uma barrinha é onde tem mais..." } \\
\text { - "Perto dessas ilhinhas, do mangue... É mais úmido para eles, } \\
\text { tem a enchente e a vazante da maré... Eles tem que se manter } \\
\text { úmido..." } \\
\text { - "Gostam de ficar em toda a parte, mas nessas partes atrás da } \\
\text { ilha tem em maior quantidade... Porque perto das pedras deve } \\
\text { ter mais alimento..." } \\
\text { - "Tem mais alimento perto da pedra... Eles ficam tanto na areia } \\
\text { quanto na lama..." }\end{array}$ \\
\hline & Siri-azul & $\begin{array}{l}\text { - "Ficam mais aqui na frente (perto do mangue e de uma das } \\
\text { ilhas)... é onde eu pego muito siri... A gente não vai nem com } \\
\text { isca, só com o ganchinho..." } \\
\text { - "Eles ficam nessas partes mais rasas, onde o fundo é mais } \\
\text { lamoso... O siri adora lama né. Por isso que tem muito..." } \\
\text { - "Vem pra criar e comer. É onde tem bastante alimento eles..." } \\
\text { - "Tudo que ele encontra no fundo ele consome..." }\end{array}$ \\
\hline & $\begin{array}{l}\text { Camarão- } \\
\text { ferrinho }\end{array}$ & $\begin{array}{l}\text { - "Essa área aqui toda, daqui pra cá é camarão... Porque tem } \\
\text { um canalzinho de lama. O camarão gosta mais desse lado de } \\
\text { lama porque ele se enterra na lama..." } \\
\text { - "Ele gosta daqui justamente pelo tipo de fundo que é uma lama } \\
\text { né... Ali tem como ele se alimentar. O fundo ali favorece..." } \\
\text { - "Eles gostam da lama, algas, limo..." }\end{array}$ \\
\hline \multirow[t]{2}{*}{$\begin{array}{l}\text { Áreas no } \\
\text { entorno } \\
\text { das } \\
\text { ilhotas e } \\
\text { costeiras }\end{array}$} & Mija-mija & $\begin{array}{l}\text { - "Gostam de ficar na areia mas mais rente às pedras... Acho } \\
\text { que perto das pedras deve ter mais alimento pra ele..." } \\
\text { - "Eles ficam perto das pedras... Acho que é por causa da lama } \\
\text { e porque tem bastante detrito ali com sedimento mais grosso... " } \\
\text { - "O mija-mija eu não sei se é por causa do cascalho que fica ao } \\
\text { redor das pedras, mas eles ficam ali também, nas ilhotas... Fica } \\
\text { abrigado..." }\end{array}$ \\
\hline & Polvo & $\begin{array}{l}\text { - "Polvo gosta de pedra, de cascalho. Ele come siri, bichos de } \\
\text { conchas... Tem um que a gente chama de chave, ele adora } \\
\text { aquilo. E na toca deles sempre tem conchas perto..." } \\
\text { - "Nas pedras das duas ilhotas tem bastante pequeno... Mas a } \\
\text { gente não tira. Só quando acha um maior... Na ponta do Araçá, } \\
\text { todinha aquela ponta ali, ali tem muito polvo... }\end{array}$ \\
\hline $\begin{array}{l}\text { Banco } \\
\text { de areia } \\
\text { (em } \\
\text { frente as } \\
\text { ilhotas e } \\
\text { próximo } \\
\text { a Ponta } \\
\text { do } \\
\text { Araçá) }\end{array}$ & $\begin{array}{l}\text { Tamburu- } \\
\text { taca }\end{array}$ & $\begin{array}{l}\text { - "Aqui nesse pontalzinho, que tem que nem uma cabeceira, um } \\
\text { banco que fica aqui, tem tamburutaca né... Na maré baixa que } \\
\text { você vai lá e acha ela..." } \\
\text { - "Pegando essa faixa aqui, mais ou menos aqui, é uma } \\
\text { bancada de areia que é um excelente criadouro de } \\
\text { tamburutaca..." } \\
\text { - "Ela mora naquele local e não muda a morada. Ali a terra é boa } \\
\text { porque é uma lama compactada por baixo e por cima é areia. E } \\
\text { tem vários crustáceos que ela come, então ela gosta desse local } \\
\text { aí..." } \\
\text { - "Acho que elas gostam dali por causa da consistência da lama } \\
\text { lá... Acho que é porque é mais firme. É uma mistura de lama e } \\
\text { areia... Pra cá é mais mole..." }\end{array}$ \\
\hline
\end{tabular}




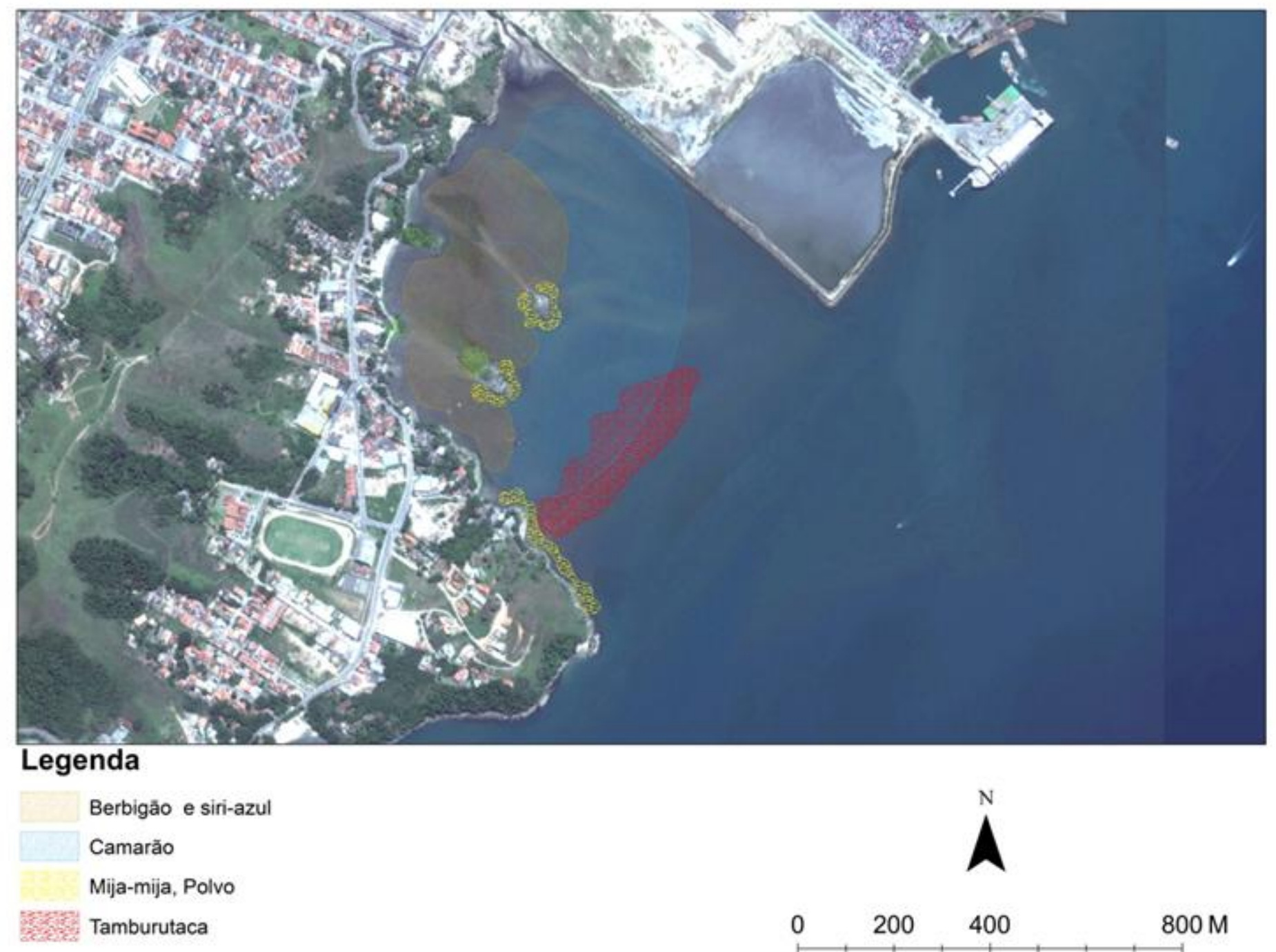

Figura 24: Localização dos habitats aquáticos das 6 principais etnoespécies de invertebrados, capturadas pelos pescadores no território pesqueiro do Araçá. 


\section{A influência de fenômenos físico-oceanográficos na pesca}

No território pesqueiro do Araçá, sobretudo na área interna da baía (uma região rasa e de baixa declividade), as variações de maré são um dos principais fenômenos físico-oceanográficos que influenciam a atividade pesqueira.

Considerando essas variações ao longo do dia, usualmente, os pescadores distinguem três momentos: "maré cheia" (alta) - que favorece a pesca de peixes; "meia maré" (média) - que favorece a captura de invertebrados que possuem boa mobilidade, como os camarões (ferrinho e sete-barbas) e o siris (azul e candeia); e "maré seca" (baixa) - que favorece a catação invertebrados de baixa mobilidade (sedentários ou sésseis), como berbigão, mija-mija, tamburutaca. Assim, em cada "momento" da maré os pescadores expressam formas diferentes de apropriação do território marítimo local na busca por recursos.

Por ser uma região rasa e de baixa declividade, grande parte dessa área, ora fica emersa (durante períodos de maré baixa), ora a fica submersa (durante períodos de maré alta) (AMARAL et al., 2015). Sendo assim, segundo os pescadores, nessa região (área interna da Baía do Araçá) a melhor condição de captura das diversas etnoespécies de peixes é, principalmente, durante períodos de maré cheia (alta), pois tal condição facilita a circulação dos cardumes próximos aos manguezais e ilhotas, onde os pescadores pescam de linha ou deixam suas redes.

No caso dos invertebrados, as melhores condições de altura da maré para captura são variáveis (Tabela 8) e dependem dos habitats preferenciais onde tais espécies ocorrem. Etnoespécies como o berbigão, o mija-mija e a tamburutaca, que ficam enterradas em áreas rasas de fundo arenoso/lamoso, são mais fáceis de serem "catadas" durante a maré seca (baixa). Já etnoespécies que tem maior mobilidade, como o siri, o camarão e o polvo, tem sua captura favorecida tanto em condições de meia maré (meia altura ou maré média), quanto em condições de maré baixa.

Os peixes ocorrem em toda baía, principalmente, na maré-cheia... Eles passam dentro do manguezal e não tem ponto fixo... (...) Com a maré cheia tem peixe em todo lugar e principalmente entre os 2 ilhotes que é uma parte mais funda... 
(...) O peixe sabe o momento certo... Ali onde tem o mangue eles entram principalmente na maré de sizígia... Quando fica tudo isso aqui alagado... (Pescador 9, 41 anos)

Toda essa região aí, mais rasa, tem muito siri... Então tem que ter uma maré média... (Pescador 16, 62 anos)

Berbigão eu pego na maré seca mais nessa faixa da ilhinha aqui, na frente da minha casa... Vou experimentando em diversos lugares, onde eles estiverem eu fico pegando... (Pescador 4, 30 anos)

Tabela 8: Condições de altura da maré mais favoráveis para a captura das principais etnoespécies de invertebrados capturadas no Araçá.

\begin{tabular}{|l|c|c|c|}
\hline & Maré alta & Maré média & Maré baixa \\
\hline Berbigão & & & $\mathrm{x}$ \\
\hline Mija-mija & & & $\mathrm{x}$ \\
\hline Polvo & $\mathrm{x}$ & $\mathrm{x}$ & $\mathrm{x}$ \\
\hline Siri & & $\mathrm{x}$ & $\mathrm{x}$ \\
\hline Camarão & & $\mathrm{x}$ & $\mathrm{x}$ \\
\hline Tamburutaca & & & $\mathrm{x}$ \\
\hline
\end{tabular}

Outro fenômeno que influencia as escolhas dos pescadores ao determinarem as estratégias de captura e as etnoespécies alvo de suas pescarias, são as chamadas “águas de sul” e "águas de leste" (Figura 25). Segundo os pescadores, as águas de sul ocorrem quando as correntes se deslocam da região sul/sudoeste do Canal de São Sebastião para o sentido norte/nordeste e são águas mais quentes e mais claras (com baixa turbidez) (Tabela 9). Por outro lado, as águas de leste se deslocam da região norte/nordeste do Canal de São Sebastião para o sentido sul/sudoeste, e são mais frias e barrentas (com maior turbidez) (Tabela 9).

Tabela 9: Características das águas de sul em comparação as das águas de leste, segundo os pescadores do Araçá.

\begin{tabular}{|l|l|}
\hline \multicolumn{2}{|c|}{ Águas de sul x Águas de leste } \\
\hline $\begin{array}{l}\text { "O pessoal chama de água de sul quando } \\
\text { vem de sul pra norte..." }\end{array}$ & $\begin{array}{l}\text { "Quando vem do norte para cá o } \\
\text { pessoal chama de água de leste..." }\end{array}$ \\
\hline $\begin{array}{l}\text { "Aqui a água clara é de sul porque vem } \\
\text { do canal..." }\end{array}$ & $\begin{array}{l}\text { A água de leste, que vem da Enseada } \\
\text { de Caraguatatuba, é barrenta..." }\end{array}$ \\
\hline "Água de sul é água quente..." & "A maré de leste é mais gelada..." \\
\hline
\end{tabular}

Essas diferenças na condição "físico-química" e no regime de circulação das águas acabam refletindo sobre características da pesca na baía, pois 
favorecem a captura de diferentes etnoespécies. Enquanto as águas de sul favorecem a captura de etnoespécies como garoupa, robalo, espada e polvo, as águas de leste favorecem a captura da corvina, da betara e do camarão. Tais características são evidências nítidas da influência desses fenômenos oceanográficos na pesca local.

Você tem as vezes a influência da correnteza que tira ou trás (os camarões e peixes)... (Pescador 16, 62 anos)

Depende da posição da maré, que a gente vê pelos barcos apoitados... Tendo água de sul, a gente vai até o farol do moleque e vem voltando com a deriva com a maré (pescando)... (...) Elas (corvinas) gostam mais de água gelada, água de leste...(...) Água de sul é mais pra tainha, garoupa, robalo, espada. A água de leste é melhor pra pegar corvina, betara, que são peixes de água gelada... (Pescador 2, 60 anos)

Garoupa tem que ser água de sul, vento de sul, aquela viraçãozinha maneira de sul. Já um noroeste bravo não pega... (Pescador 3, 72 anos)

A água de leste você pega mais camarão. Na água de sul eles somem... Polvo eu pego com água clara, água de sul... (Pescador 8, 43 anos) 

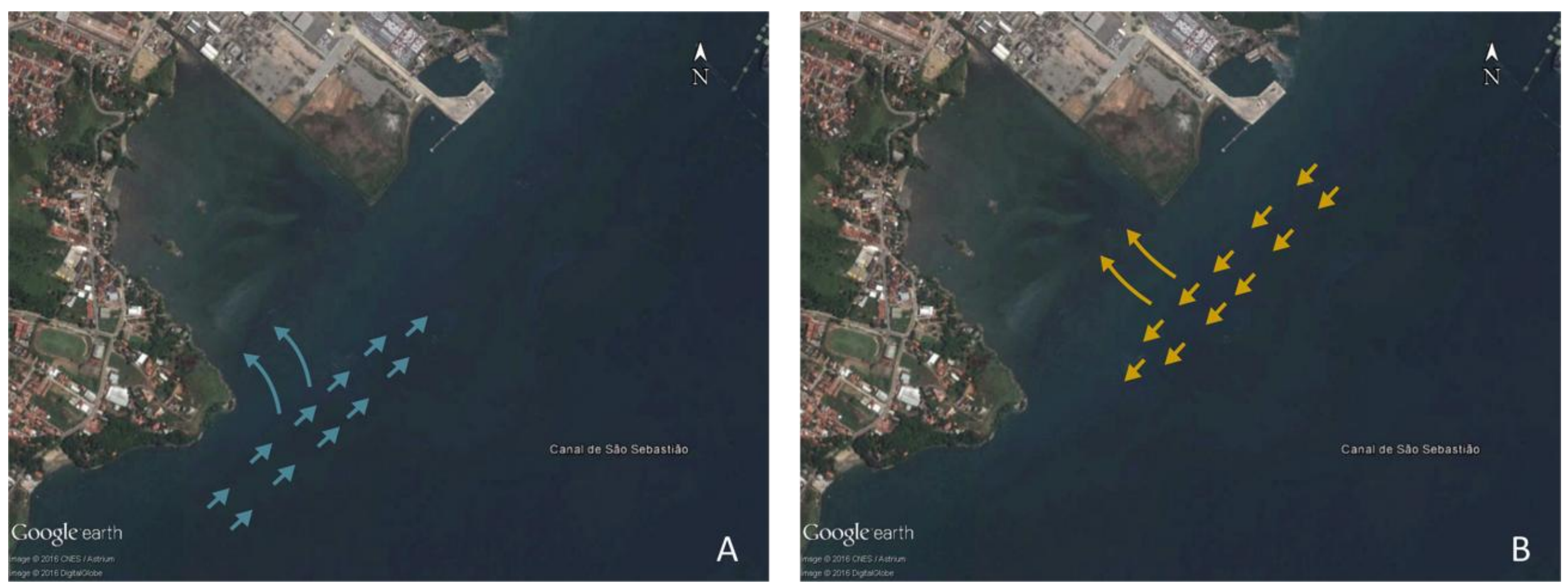

Figura 25: Águas de sul (A) e águas de leste (B) representadas por flechas em azul e amarelo, respectivamente, orientadas segundo a descrição dos pescadores entrevistados. 
Além das variações de altura da maré e das águas de sul e águas de leste, os pescadores entrevistados também mencionaram um terceiro fenômeno, chamado de "revessa de maré". Conforme explicaram os pescadores, a revessa é um fenômeno de rotação das águas no interior da baía, que ocorre associado a subida da maré e a entrada das águas que vem do Canal de São Sebastião. Para eles, a revessa é o próprio movimento de giro das águas que circulam no interior da Baía do Araçá, no sentido horário ou anti-horário, dependendo do regime dominante de águas que vem do canal (águas de sul ou águas de leste) (Figura 26). Embora os pescadores não tenham feito nenhuma menção de influência da revessa de maré na pesca, todos os que citaram esse fenômeno o citaram como responsável por "trazer o lixo" e por reter "a lama" que chega nas áreas mais rasas da baía e fica depositado nas praias e manguezais (principalmente na porção esquerda/oeste, localizada na margem oposta ao cais do porto).

A maré entra por aqui pelo canto e fica rodando entendeu... Ela entra e fica rodando aqui, por isso que fica tudo aqui... Eles (os peixes) entram pela encosta seguindo a revessa da maré e entram por tudo isso aqui...(...) Aqui faz uma revessa de maré e não joga a lama pra lá entendeu... Quando a maré vem e chega aqui ela fica rodando. A gente fala que essa praia aqui é o encontro de coisa ruim porque tudo que cai de lixo do lado de lá cai aqui... (Pescador 1, 49 anos)

Vamo dizer assim, é uma revessa. Se tiver de sul, a água de sul, ela entra indo no sentido norte. Quando ela bate aqui ela vem ao contrário, a revessa é pra cá... E ali é a mesma coisa se ela vai pra lá, para o sul (água de leste), ela chega lá e volta pra cá... (indicando no mapa) É a revessa... (Pescador 3, 72 anos)

Conforme a correnteza tá de leste ou de sul eles (peixes) entram aqui pra se abrigar... Por um lado ou pelo outro... Aí conforme a maré vem ela chega aqui dentro bate e roda... (Pescador 4, 30 anos) 

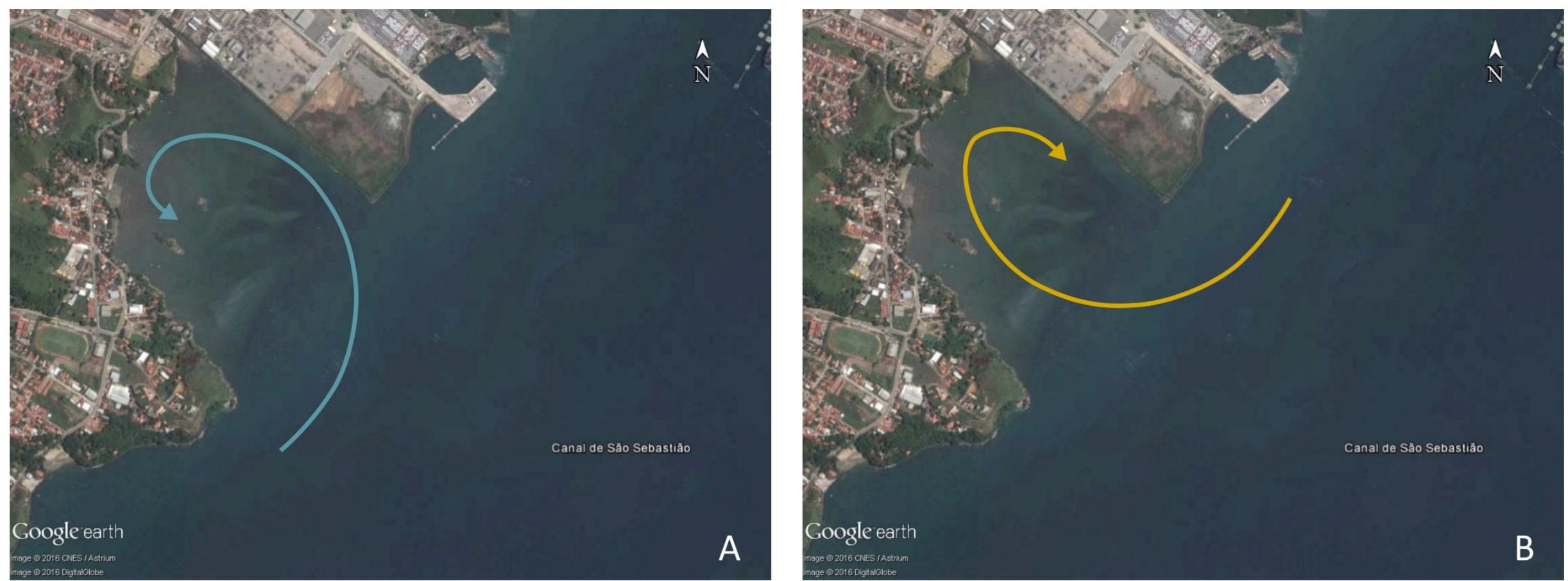

Figura 26: A revessa de maré no interior da Baía do Araçá (simbolizada por flechas em azul e amarelo) representada tanto durante o regime de águas de sul (A), como durante o regime de águas de leste (B), conforme a descrição dos pescadores entrevistados. 


\section{OPINIÕES E CONTRIBUIÇÕES PARA A GESTÃO LOCAL}

\section{Importâncias e problemas do Araçá}

Pautados nessa relação íntima com o território e no conhecimento que possuem dele, os pescadores mencionaram diversas importâncias/pontos positivos da região do Araçá (Tabela 10), atreladas aos serviços e benefícios prestados pelo ecossistema local. Dentre essas importâncias destacaram-se: a provisão de alimentos e de renda através da pesca; a existência de locais apropriados para a prática de atividades de lazer (canoagem, natação e a própria pesca); e o fato de a baía ser um "viveiro natural" para a reprodução de espécies marinhas.

Tabela 10: Importâncias atribuídas a Baía do Araçá pelos pescadores entrevistados.

\begin{tabular}{|c|c|}
\hline Importâncias & Trechos das entrevistas \\
\hline $\begin{array}{l}\text { Fonte } \\
\text { alimentar e de } \\
\text { renda (pesca) }\end{array}$ & $\begin{array}{l}\text { - "É a pesca né. (...) Se quiser matar um peixinho..." } \\
\text { - "É um lugar que nos abastece, nos dá peixe..." } \\
\text { - "Além da beleza natural, é uma renda... Uma renda que vem da } \\
\text { pesca e do mergulho. É juntar o útil ao agradável..." } \\
\text { - "Daqui a gente tira nosso alimento, nosso lucro, isca pra poder } \\
\text { pescar... Fora que os peixes criam aqui." }\end{array}$ \\
\hline $\begin{array}{l}\text { Recreação e } \\
\text { lazer }\end{array}$ & $\begin{array}{l}\text { - "Aqui eu faço minha pescaria, vou rema de canoa, vou } \\
\text { mergulhar..." } \\
\text { - "Nas horas vagas ou estou surfando, ou pescando, ou na praia, } \\
\text { ou remando de canoa..." } \\
\text { - "Vou mergulhar... Remar de canoa..." }\end{array}$ \\
\hline Beleza cênica & $\begin{array}{l}\text { - "Ah, o lugar também é maravilhoso..." } \\
\text { - "Além do que me agrada demais é a paisagem né, a natureza!" } \\
\text { - "Admiro a natureza, a paisagem..." }\end{array}$ \\
\hline $\begin{array}{l}\text { Saúde e } \\
\text { tranquilidade }\end{array}$ & $\begin{array}{l}\text { - "Pra mim isso aqui é saúde! Se estou estressado vou ali dar uma } \\
\text { volta no mar e já volto tranquilo." } \\
\text { - "Saúde aqui é tudo de bom..." } \\
\text { - "Muita paz. Uma certa tranquilidade, o sossego, um silêncio..." } \\
\text { - "É uma válvula de escape, uma higiene mental..." } \\
\text { - "O habitat, a tranquilidade de vida que é aqui..." }\end{array}$ \\
\hline $\begin{array}{l}\text { "É tudo", "É } \\
\text { minha vida" } \\
\text { (identidade } \\
\text { cultural, } \\
\text { afinidade com } \\
\text { o local) }\end{array}$ & $\begin{array}{l}\text { - "A importância daqui da Baía do Araçá é tudo! Em matéria de } \\
\text { renda, em matéria de alimentação e em matéria de saúde..." } \\
\text { - "É minha vida... Pra mim é de fundamental importância..." } \\
\text { - "Aqui é tudo de bom! Você tem o contato com a natureza, pode } \\
\text { preservá-la..." }\end{array}$ \\
\hline
\end{tabular}


Tabela 10 (continuação): Importâncias atribuídas a Baía do Araçá pelos pescadores entrevistados.

\begin{tabular}{|c|c|}
\hline $\begin{array}{l}\text { Viveiro natural, } \\
\text { berçário }\end{array}$ & $\begin{array}{l}\text { - "Isso aí para nós é um santuário, porque aí tem tudo quanto é } \\
\text { espécie. Elas criam aí nessa bacia..." } \\
\text { - "Enxergo como um lugar de reprodução de espécies em todos os } \\
\text { sentidos. (...) Perdendo isso aí estaremos perdendo um habitat } \\
\text { natural que nós temos, peixes que se reproduzem..." } \\
\text { - "Acho que a importância não é só para mim, é para a } \\
\text { humanidade. Isso é um viveiro marinho..." }\end{array}$ \\
\hline Biodiversidade & $\begin{array}{l}\text { - "O Araçá é muito rico em biodiversidade..." } \\
\text { - "A princípio a importância é essa biodiversidade que tem de } \\
\text { peixes, de crustáceos, mariscos..." }\end{array}$ \\
\hline & - "A importância é esse mangue... Tudo o que a Baía me oferece..." \\
\hline $\begin{array}{l}\text { Abrigo e } \\
\text { guarda de } \\
\text { embarcações }\end{array}$ & $\begin{array}{l}\text { - "É um dos locais que ainda sobrou pra gente chegar, puxar } \\
\text { nossas canoas, deixá-las aí..." } \\
\text { - "A praia do Deodato também serve como porto. É usado pra } \\
\text { navegação de praia a praia... Como as canoas... As pessoas } \\
\text { abastecem aqui e partem... }\end{array}$ \\
\hline $\begin{array}{l}\text { Pesquisas } \\
\text { científicas }\end{array}$ & $\begin{array}{l}\text { - "É importante para os pesquisadores que vem na lua nova, na lua } \\
\text { cheia, com a maré seca... Eles vem pra pesquisar aí direto..." }\end{array}$ \\
\hline
\end{tabular}

Embora haja inúmeros motivos para que os pescadores da Baía do Araçá valorizem o local e reforcem sua importância, existem preocupações, ressalvas e desconfianças em relação ao futuro do lugar. Nesse contexto, foram citados diversos problemas e fragilidades da região (Tabela 11), ligados a temas como o desenvolvimento local, problemas ambientais e de saúde pública, e a falta de planejamento e o desamparo do poder público. O projeto de expansão do Porto de São Sebastião (cuja licença prévia foi anulada após a data de realização das entrevistas com os pescadores) também foi lembrado e citado como um assunto de preocupação. 
Tabela 11: Problemas do Araçá segundo a opinião dos pescadores entrevistados.

\begin{tabular}{|c|c|}
\hline Problemas & Trechos das entrevistas \\
\hline $\begin{array}{l}\text { Poluição por lixo } \\
\text { e entulhos }\end{array}$ & $\begin{array}{l}\text { - "O próprio lixo, a sacola, vai matando o mangue. (...)Se } \\
\text { colocassem uma tela ali, não era pra vir lixo pra cá..." } \\
\text { - "Tem muito lixo. Encosta muito lixo aqui na praia..." } \\
\text { - "Aqui do lado fizeram um deposito de lixo e entulho..." }\end{array}$ \\
\hline $\begin{array}{l}\text { Poluição por } \\
\text { descargas de } \\
\text { esgoto }\end{array}$ & $\begin{array}{l}\text { - "A sujeira, muita lama, esgoto que vem das casas daqui e de lá } \\
\text { de cima..." } \\
\text { - "As valas que tem e que desaguam lá. Todas as impurezas e } \\
\text { lixo que descem com a correnteza e deságuam lá..." }\end{array}$ \\
\hline $\begin{array}{l}\text { Petrobrás } \\
\text { (acidentes/ } \\
\text { vazamentos) }\end{array}$ & $\begin{array}{l}\text { - "Já houve petróleo que caiu aqui que foi uma grandeza. Acabou } \\
\text { com tudo, o petróleo foi terrível. Eu estava aqui em todas as } \\
\text { épocas. Outros derramamentos que houve eu vi também. Atingiu } \\
\text { tudo. Mas graças a Deus hoje está mais tranquilo. Eles fazem } \\
\text { barreira e muitas coisas que não faziam antes..." }\end{array}$ \\
\hline $\begin{array}{l}\text { Porto de São } \\
\text { Sebastião }\end{array}$ & $\begin{array}{l}\text { - "O porto. Não acho que é um porto legal..." } \\
\text { - "Esse porto aí... Tem emprego, mas é muito restrito. Para os } \\
\text { pescadores foi muito prejudicial... Afetou a nossa preservação } \\
\text { mas é um mal necessário..." } \\
\text { - "E tem isso, daquele cais lá (do porto) até tantos metros pra cá } \\
\text { você não pode pescar..." }\end{array}$ \\
\hline $\begin{array}{l}\text { Projeto de } \\
\text { ampliação do } \\
\text { porto }\end{array}$ & $\begin{array}{l}\text { - "Aumenta o porto mas não se pensa em saúde, segurança, em } \\
\text { qualidade de vida... Ai vem o porto e vem tráfico de drogas, } \\
\text { prostituição, doenças..." } \\
\text { - "Essa chegada do porto que estão falando não vai só afetar lá. } \\
\text { Vai afetar aqui também... Pode acabar com tudo né... o Mangue } \\
\text { aqui não vai suportar. Tem muita gente que vai sair daqui..." }\end{array}$ \\
\hline $\begin{array}{l}\text { Surgimento de } \\
\text { novas indústrias }\end{array}$ & $\begin{array}{l}\text { - "Tem indústria que vai começar a vir pra cá. (...) Os galpões } \\
\text { estão crescendo... Então acho que a industria pode tomar conta } \\
\text { dessa parte aqui... Seria a destruição total dessa parte costeira } \\
\text { aqui..." }\end{array}$ \\
\hline $\begin{array}{l}\text { Presença de } \\
\text { usuários de } \\
\text { drogas }\end{array}$ & $\begin{array}{l}\text { - "Atualmente o que me incomoda é a poluição das drogas... } \\
\text { Porque não são os habitantes, os drogados vem de fora..." } \\
\text { - "Deveriam fazer algo para tirar esses 'nóias'... Eles sujam tudo } \\
\text { ali..." } \\
\text { - "Hoje em dia vocês veem uma incidência muito grande de } \\
\text { usuários de crack..." }\end{array}$ \\
\hline $\begin{array}{l}\text { Descaso do } \\
\text { poder público }\end{array}$ & $\begin{array}{l}\text { - "A prefeitura se acomodou... Eles não limpam aqui. Ficam } \\
\text { esperando a população limpar..." } \\
\text { - "A própria prefeitura não toma conhecimento de uma área tão } \\
\text { bonita como essa pra cuidar. É um descaso..." }\end{array}$ \\
\hline $\begin{array}{l}\text { Falta iluminação } \\
\text { nas áreas de } \\
\text { acesso à baía e } \\
\text { obstrução das } \\
\text { mesmas }\end{array}$ & $\begin{array}{l}\text { - "De um tempo pra cá também poderiam iluminar esse caminho } \\
\text { aqui, que dá acesso a praia..." } \\
\text { - "Estão fechando a entrada aqui... A prefeitura com a SABESP } \\
\text { fecharam a entrada onde tinha um caminho ali... Foram lá e } \\
\text { fecharam..." }\end{array}$ \\
\hline $\begin{array}{l}\text { Conflitos entre a } \\
\text { população local }\end{array}$ & $\begin{array}{l}\text { - "Quando vão fazer reunião aqui, tem uns aí que chamam uns e } \\
\text { não chamam outros. Porque eles não chamam todos? (...)" }\end{array}$ \\
\hline
\end{tabular}




\section{Perspectivas futuras desejadas para a região}

Ao refletir sobre o que desejam para o futuro da Baía do Araçá, , a preocupação com a melhoria das condições ambientais e com a preservação/conservação da biodiversidade marinha na baía ficaram evidentes nos discursos dos entrevistados, sendo compartilhada por todos.

Visando minimizar os problemas, maximizar as importâncias e contribuir com melhorias almejadas, os pescadores sugeriram diversas ações que poderiam ser tomadas. As principais sugestões foram: a descontinuidade do projeto de ampliação do Porto de São Sebastião; a tomada de ações para redução da poluição das praias e das águas; o desenvolvimento de ações visando a manutenção da tradição da pesca; a continuidade de atividades de pesquisa; e o incentivo ao uso da baía como um local de visitação turística. Além dessas ações, também foram citadas ao longo das entrevistas a necessidade de melhorar as condições de infraestrutura urbana (p.ex.: iluminação e saneamento básico), aumentar a divulgação a respeito da região na mídia, e realizar atividades de educação ambiental e conscientização com a população local, para sensibilizar as pessoas com relação a importância de conservação do Araçá.

Eu gostaria de ver isso aqui como era antigamente. Que houvesse mais caiçaras que fizessem a nossa pesca, para que não morresse essa nossa arte caiçara... (Pescador 12, 37 anos)

Tem que manter preservado... Tentar ver como se resolve essa situação desses córregos que deságuam lá contaminando... Talvez se fizesse o tratamento desse esgoto, a produção dos organismos ali seria muito maior... (Pescador 16, 62 anos)

Teria que ter é um olhar mais cuidadoso, de preservação... E os órgãos competentes, a prefeitura, devia olhar mais pra isso também... (...) Poderia até ser um ponto turístico... Gostaria que fosse preservado. Que pudesse ser motivo de pesquisa... Da biodiversidade que tem aqui no mangue... (Pescador 13, 27 anos)

Teria que ter isso aqui como local de pesquisa, sede fixa de pesquisa, ter uma faculdade de biologia para os alunos 
terem contato direto com a natureza... Eu acho que quanto mais vier estudar isso aqui melhor ainda... Porque vai virar uma área de preservação e vão ter pessoas de olho aqui pra manter como está e não piorar ainda mais... (Pescador 9, 41 anos)

Primeira coisa, eu tiraria esse esgoto. Faria o tratamento do esgoto, fecharia essas bocas... Deviam limpar isso... Fazer a coleta certinho pra limpar as praias, o rio... Fazer uma iluminação na praia nos pontos mais críticos, onde ficam os nóias... $E$ os moradores não jogarem lixo na praia $e$ continuarem limpando a frente de suas casas... (Pescador 4, 30 anos)

Tem que ter estrutura, moradia, saneamento básico, acesso... Usar mais o espaço como espaço turístico... Vir mais gente aqui conhecer... Tem muita gente de São Sebastião que não conhece aqui... (Pescador 8, 43 anos)

Teria que ter uma divulgação maior na mídia, do que a gente tem de espécies aqui... E as pessoas ajudarem a gente a preservar... Eu torço muito para que o porto não seja ampliado. Porque aqui tem muita coisa viva que deve ser preservada... (Pescador 11, 44 anos)

Para os pescadores o principal responsável que deveria levar à frente ações de melhoria em prol da preservação e conservação da região do Araçá é o poder público municipal. Por serem considerados agentes indutores de muitas das mudanças locais que ocorreram, o Porto de São Sebastião e a Petrobrás também foram citados como instituições que deveriam fomentar melhorias na região (em compensação aos impactos gerados). O papel da própria comunidade local e individual de cada um (responsabilizando a si próprios) também foi ressaltado pelos pescadores, o que demonstra o senso de responsabilidade com relação ao futuro da região. Órgãos públicos federais, como o Ibama, e estaduais, como a Sabesp, assim como instituições de pesquisa (CEBIMar) e os próprios moradores da região também foram lembrados:

A prefeitura né, que até já ajuda com alguma coisinha quando agente precisa né, mas é pouco... A Petrobrás deveria ajudar mais né... Porque já prejudicaram tanto, então alguma 
coisa tinham que ajudar né... (Pescador 3, 72 anos)

O próprio município, porque a gente tem condições de uma arrecadação boa de fundos da Petrobrás, Porto. Eles só pensam no progresso deles... (Pescador 10, 45 anos)

Deveriam ser responsáveis a prefeitura, o lbama e 0 próprio porto que está instalado aí... (Pescador 8, 43 anos)

Primeiramente prefeitura e Petrobrás, e depois os moradores... (Pescador 4, 30 anos)

O porto por estar aqui deveria estar fazendo mais por isso aqui... O CEBIMar que faz as pesquisas aqui ajuda bastante... (Pescador 11, 44 anos)

Do ponto de vista pessoal, todos os entrevistados afirmaram contribuir de alguma forma para a conservação da Baía do Araçá. As ações mais frequentes realizadas por eles e citadas nas entrevistas foram: a limpeza e coleta do lixo nas áreas da baía que costumam frequentar; a participação em mutirões de limpeza das praias e dos manguezais; e a orientação de outras pessoas que frequentam a baía para que busquem conservar o local. Eventualmente, alguns também procuram participar de reuniões realizadas na comunidade para discutir questões locais e denunciar irregularidades praticadas por outras pessoas, como a pesca ilegal ou o descarte de lixo de maneira inapropriada. Os trechos de falas destacados a seguir evidenciam tais questões:

A minha participação aqui é orientar... Como te falei... É mutirão, se alguém precisa a gente ajuda... Limpeza de praia eu ajudo também... Sempre tô ali... (Pescador 3, 72 anos)

Eu quando vou pescar e acho sacola e garrafa eu junto tudo e tiro... (Pescador 4, 30 anos)

Participo de reuniões, limpezas de praias... O que eu posso fazer eu faço... (Pescador 7, 56 anos)

Denuncio dentro de um padrão que eu possa denunciar... (Pescador 9, 41 anos)

Contudo, embora os pescadores se responsabilizem individualmente por cuidar do Araçá e tenham um entendimento do que pode ser feito para melhorar as condições futuras da região, os mesmos afirmaram que há pouca mobilização das pessoas da comunidade para buscar essas mudanças. Além 
disso, eles próprios afirmaram que poderiam ter uma maior participação nesse sentido e, assim, contribuir nas discussões sobre o futuro da região.

Se caso eu visse que todos os moradores quisessem se reunir pra correr atrás de um direito nosso eu ia junto mas ninguém faz nada... (Pescador 4, 30 anos)

Se as pessoas se juntassem e a prefeitura desse uma força... A gente poderia melhora muito isso aqui... (Pescador 2, 60 anos)

Poderia ter participado mais. Um sozinho não é bom, quanto mais é melhor, ganha força... (Pescador 1, 59 anos)

Eu queria participar mais dessas reuniões e poder falar mais do que tem aqui e da viva nossa... (Pescador 11, 44 anos)

\section{A análise SWOT e o DPSIR framework}

Na realização da análise SWOT para a Baía do Araçá (SWOT/Araçá), com base nos saberes, visões e opiniões dos pescadores, os diversos fatores "positivos" e "negativos" ("internos" e "externos" ao ambiente local) que puderam ser identificados ao longo das entrevistas, foram padronizados e organizados em quatro grupos distintos (Tabela 12). Aspectos como a tranquilidade, a elevada biodiversidade e a capacidade de prover alimentos e renda, que refletem as importâncias, bens e serviços ecossistêmicos prestados pelo Araçá e que podem ser considerados como fatores positivos e internos da baía, foram agrupados como fortalezas (strengths). Fatores negativos internos, como a presença de lixo nas águas e praias, presença de efluentes de esgoto e a falta de iluminação em áreas de acesso (problemas existentes da baía), foram organizados como fraquezas (weaknesses). Do mesmo modo, questões positivas mas que podem ser vistas como influências "externas", como a possibilidade de incentivo ao uso da baía como um local de visitação e educação ambiental, bem como a realização de ações visando a despoluição e recuperação das águas, foram agrupadas como oportunidades (opportunities). Por fim, questões externas entendidas como negativas e prejudiciais, como o tráfego intenso de embarcações e os riscos de acidentes nos terminais portuários foram classificadas como ameaças (threats). 
Tabela 12: SWOT/Araçá - resultados da aplicação do modelo conceitual intitulado Análise SWOT.

\begin{tabular}{|c|c|c|c|}
\hline \multicolumn{4}{|c|}{ Análise SWOT } \\
\hline \multicolumn{2}{|c|}{ Fatores internos } & \multicolumn{2}{|c|}{ Fatores externos } \\
\hline $\begin{array}{l}\text { - Segurança e tranquilidade; } \\
\text { - Saúde e qualidade de vida; } \\
\text { - Senso de pertencimento e } \\
\text { identificação com o lugar; } \\
\text { - Beleza cênica, paisagem e } \\
\text { contato com a natureza; } \\
\text { - Manutenção da cultura caiçara } \\
\text { e da pesca artesanal; } \\
\text { - Subsistência (alimentação e } \\
\text { complementação da renda); } \\
\text { - Lazer e diversão (caminhada, } \\
\text { canoagem, mergulho, etc); } \\
\text { - Área de reprodução de } \\
\text { organismos marinhos; } \\
\text { - Alta biodiversidade; } \\
\text { - Águas calmas e rasas; } \\
\text { - Local de fácil acesso (via } \\
\text { terrestre); } \\
\text { - Presença de manguezais; } \\
\text { - Local de abrigo para } \\
\text { embarcações; } \\
\text { - Eventos comunitários (Regata } \\
\text { de Canoas); } \\
\text { - Sentimento de luta em defesa } \\
\text { pela conservação e preservação } \\
\text { da Baía do Araçá; } \\
\text { - Experts locais - conhecimento } \\
\text { ecológico tradicional. }\end{array}$ & $\begin{array}{l}\text { - Presença de lixo, entulhos e } \\
\text { destroços encalhados; } \\
\text { - Presença de esgoto irregular } \\
\text { e de esgoto proveniente do } \\
\text { emissário submarino; } \\
\text { - Falta de iluminação as áreas } \\
\text { de acesso ao mar na Baía; } \\
\text { - Presença de usuários de } \\
\text { drogas e locais pouco } \\
\text { frequentados pelas demais } \\
\text { pessoas; } \\
\text { - Iluminação noturna voltada } \\
\text { para as águas da baía ao lado } \\
\text { do porto; } \\
\text { - Restrição e fechamento de } \\
\text { passagens e áreas de acesso } \\
\text { ao mar na Baía; } \\
\text { - Desrespeito a legislação da } \\
\text { pesca (defeso, tamanho de } \\
\text { captura, artes de pesca); } \\
\text { - Falta de mobilização e } \\
\text { participação social da } \\
\text { população na busca por } \\
\text { melhorias para a região; } \\
\text { - Medo de "represália", por } \\
\text { trabalhadores de instituições } \\
\text { que possuem interesses locais. }\end{array}$ & $\begin{array}{l}\text { - Incentivos a visitação e a realização de } \\
\text { atividades de educação ambiental; } \\
\text { - Desenvolvimento do turismo comunitário } \\
\text { - Continuidade das atividades de ensino e } \\
\text { pesquisa; } \\
\text { - Ordenamento e manutenção da pesca } \\
\text { artesanal na baía; } \\
\text { - Ampliação e melhoria das áreas de } \\
\text { acesso ao mar na baía; } \\
\text { - Melhoria da qualidade da água e da } \\
\text { balneabilidade; } \\
\text { - Melhoria das condições de infraestrutura } \\
\text { pública e saneamento básico; } \\
\text { - Coletas regulares de lixo/resíduos } \\
\text { sólidos nas praias e mangues da Baía; } \\
\text { - Recuperação e despoluição dos } \\
\text { córregos que deságuam na Baía; } \\
\text { - Recuperação e conservação da } \\
\text { natureza; } \\
\text { - Recuperação do manguezal; } \\
\text { - Construção de rancho comunitário para } \\
\text { canoas; } \\
\text { - Mais atuação do poder público e de } \\
\text { instituições competentes; } \\
\text { - Desenvolvimento de políticas públicas } \\
\text { locais para o desenvolvimento } \\
\text { sustentável; } \\
\text { - Fortalecimento da participação social e } \\
\text { de acões comunitárias. }\end{array}$ & $\begin{array}{l}\text { - Aumento dos problemas } \\
\text { associados ao tráfico de } \\
\text { drogas; } \\
\text { - Ampliação do porto } \\
\text { (impactos das obras, } \\
\text { sombreamento etc.); } \\
\text { - Operação do porto atual } \\
\text { (refletores, poluição, aterro, } \\
\text { conflitos etc.); } \\
\text { - Crescimento urbano } \\
\text { desordenado; } \\
\text { - Tráfego intenso de } \\
\text { embarcações } \\
\text { (principalmente devido aos } \\
\text { terminais portuários); } \\
\text { - Acidentes na rodovia SP- } \\
\text { 55; } \\
\text { - TEBAR/Petrobrás } \\
\text { (poluição, acidentes e } \\
\text { vazamentos de óleo, etc); } \\
\text { - Descaso do poder público } \\
\text { e ausência de planejamento } \\
\text { e de políticas para melhoria } \\
\text { da região; } \\
\text { - Crescimento das } \\
\text { atividades industriais e } \\
\text { semi-industriais no entorno } \\
\text { da Baía. }\end{array}$ \\
\hline
\end{tabular}


$\mathrm{Na}$ aplicação do modelo DPSIR a partir do CT e das percepções dos pescadores entrevistados sobre a Baía do Araçá (DPSIR/Araçá, Figura 27), informações referentes a questões políticas, econômicas e sociais, numa escala regional, mas que levam a mudanças locais como, por exemplo, o crescimento populacional e urbano desordenado e o desenvolvimento de atividades marítimas (portos e indústria petrolífera), foram classificadas como driving forces (fatores/forçantes indutoras de mudanças - D). Consequências desses fatores como o despejo irregular de resíduos sólidos e de efluentes de esgoto, e a poluição por resíduos derivados das atividades portuária e petrolífera, foram consideradas como pressures (pressões antrópicas - P). Tais pressões podem influenciar diretamente ou indiretamente características ambientais como a biodiversidade e a qualidade das águas, que refletem o estado do ambiente local (state of the environment - S). A ação das pressões sobre o estado do ambiente, alterando suas condições e características, resultou nos impactos (impacts - I), como a redução da qualidade da água, da segurança alimentar e da biodiversidade. Para enfrentar as mudanças ambientais decorrentes dessas relações, os entrevistados declararam que são necessárias repostas (responses - R) como uma ação mais efetiva do poder público na gestão local e o desenvolvimento de políticas de combate a poluição. 


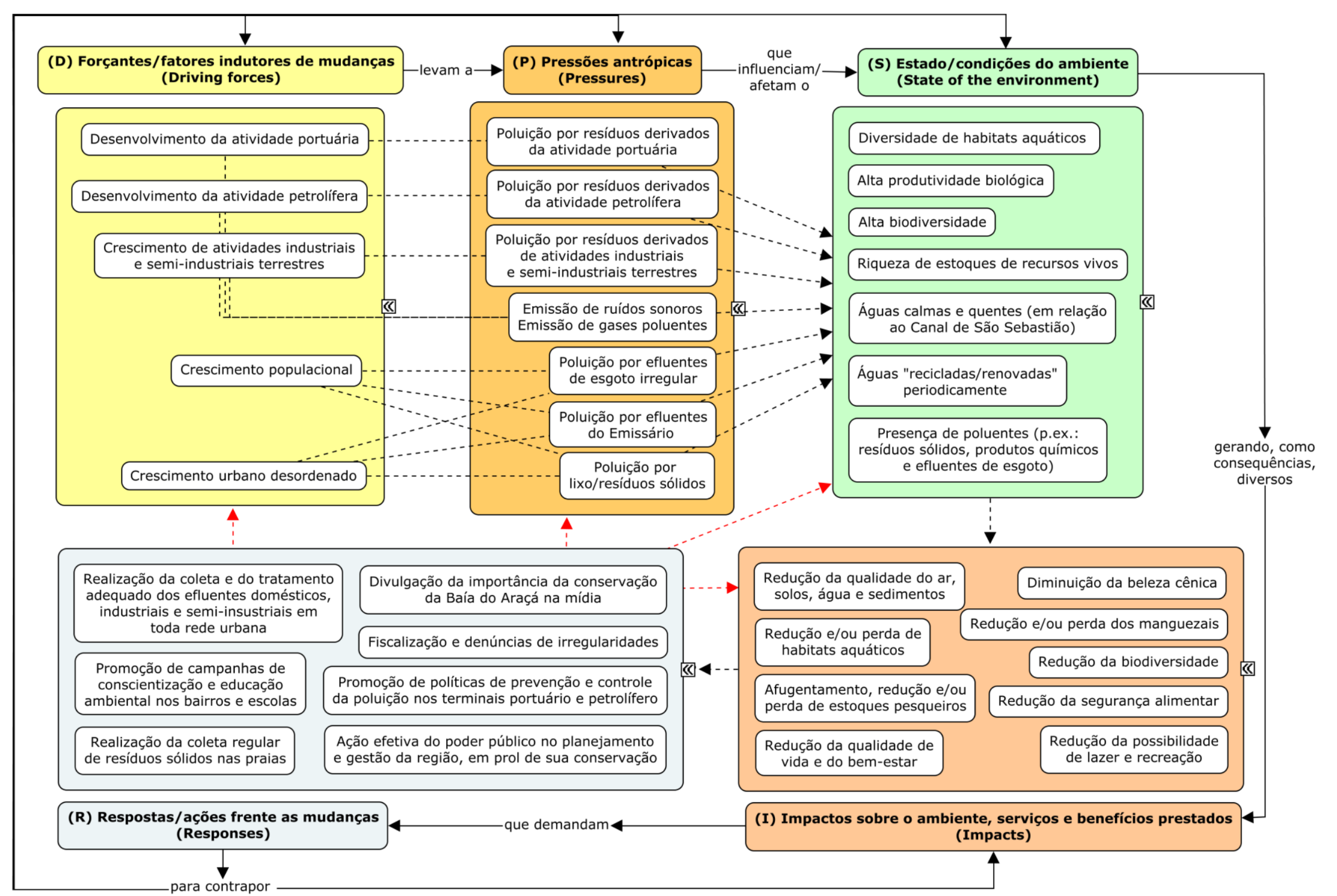

Figura 27: DPSIR/Araçá - aplicação do modelo DPSIR para a Baía do Araçá (com base nas informações obtidas a partir do CT e das percepções dos pescadores entrevistados) exemplificando as relações entre causas e consequências dos problemas ambientais locais 


\section{DISCUSSÃO}

Os 18 pescadores artesanais entrevistados nesse trabalho são nativos da região litorânea e se reconhecem enquanto caiçaras o que, segundo eles mesmos, significa preservar um estilo de vida ligado ao mar, à pesca artesanal e ao uso da canoa como meio preferencial de transporte marítimo, em concordância com aspectos dessa cultura destacados por autores como MUSSOLINI (1980), BEGOSSI (1998), ADAMS (2000a), WILLEMS (2003) e DIEGUES (2004a). O fato de se reconhecerem como caiçaras, demonstra a identificação que possuem com essa cultura (enquanto uma cultura distinta) e, por si só, já é uma característica fundamental para que possam ser vistos como uma população tradicional (DIEGUES; NOGARA, 1999; DIEGUES, 2004a, 2008). Do ponto de vista da legislação brasileira, tal afirmação também é válida, uma vez que esse autoreconhecimento foi incorporado como uma premissa na definição de "Povos e Comunidades Tradicionais" do Decreto no 6.040/2007, que instituiu a Política Nacional de Desenvolvimento Sustentável dos Povos e Comunidades Tradicionais (NOHARA, 2016).

Ao constatar que os entrevistados vivem em uma região urbanizada $e$ que sua rotina está ligada, ao mesmo tempo, ao "dia-a-dia" da cidade e da pesca, esses pescadores podem ser vistos como pescadores artesanais urbanos, assim como observado por DIEGUES (2004a) em outras localidades do litoral paulista. Mesmo que poucos entrevistados dependam exclusivamente da pesca enquanto uma fonte de renda, para eles essa é uma atividade importante que thes fornece alimento e é, sobretudo, um elemento fundamental de sua tradição. Portanto, pode-se dizer que a pesca artesanal se tornou 0 principal elo desses pescadores com sua identidade cultural caiçara, de forma similar ao que foi relatado por CLAUZET e BARELLA (2004) em sua pesquisa realizada na Praia Grande do Bonete, em Ubatuba (São Paulo).

Diversos autores ressaltam a importância da pesca na tradição das populações marítimas, relacionando-a ao domínio (pelos pescadores) de um conjunto de saberes práticos e cognitivos que são essenciais para o sucesso nessa atividade (GADGIL et al., 1993; BERKES et al., 1995; RUDDLE, 2000; DIEGUES, 2004b). Conforme afirmou DIEGUES (2004b, p.87): 
cerne da própria pesca artesanal: o domínio do saber-fazer e do conhecer que forma o cerne da 'profissão'. Esta é entendida como domínio de um conjunto de conhecimentos e técnicas que permitem ao pescador se reproduzir enquanto tal. Esse controle da "arte da pesca" que se aprende com "os mais velhos...

A transmissão desse conjunto de conhecimentos e técnicas tradicionais através das gerações é um fator intrínseco da reprodução, aperfeiçoamento e adaptação do modo de vida dessas populações tradicionais (GADGIL et al., 1993; BERKES et al., 1995; RUDDLE, 2000; DIEGUES, 2004b). No Araçá, os pescadores entrevistados deram seus primeiros passos na pesca ainda na infância e o aprendizado inicial se deu pela observação e pela prática através da convivência colaborativa com pescadores antigos, geralmente o pai, tios ou avôs. Os pescadores também costumam ensinar/transmitir conhecimentos sobre a pesca para outras pessoas, normalmente filhos, sobrinhos e amigos, o que gera um fluxo de informação intergerações, evidenciando a importância da família nesse processo de perpetuação dos saberes patrimoniais pesqueiros. Quebrar esse fluxo de informações poderia comprometer essa memória imaterial (BERKES et al.2000; DIEGUES, 2004b; 2008) e, consequentemente, a manutenção do modo de vida tradicional na região.

Todos os entrevistados pescam na Baía do Araçá e em áreas adjacentes (como a Ponta do Araçá, a Praia Preta e o Farol do Moleque), região que configura-se como o território pesqueiro desses pescadores, conforme a concepção de GODELIER (1984). Embora esse território possa ser representado como uma área contínua e restrita a uma porção do espaço marítimo, as fronteiras existentes são "fluidas", eventualmente descontínuas, e de difícil demarcação (DIEGUES, 2008). Ainda assim, foi possível estabelecer uma área aproximada para o território pesqueiro do Araçá, que pode ser utilizado para se discutir propostas de ordenamento marinho da região considerando o CT dos pescadores e seus mecanismos tradicionais de apropriação desse espaço e seus recursos.

É através do CT a respeito de seu território que os pescadores desenvolvem formas próprias de apropriação, manejo, exploração e controle de seu espaço pesqueiro (CORDELL, 2001; DIEGUES 2004b). No Araçá, a 
seleção e uso de diferentes métodos e artes de pesca dependem do conhecimento e da interpretação das condições do mar e do tempo, bem como da sazonalidade, comportamento e hábitats preferenciais das espécie-alvo. Tal conduta, reflete o fato de que na pesca, a natureza se impõe a sua maneira sendo, apropriada pelo pescador num "sistema de produção próprio que se articula com o social" (CUNHA, 2000, p.106). Assim, esse conjunto de conhecimentos e práticas é considerado fundamental para o sucesso das comunidades tradicionais pesqueiras, bem como para a gestão de seus territórios (DIEGUES; NOGARA, 1999; MOURA, 2013; RUDDLE, 2000; CORDELL, 2001; DIEGUES, 2004b; RAMIRES et al., 2007).

Para o caiçara, cujo dia a dia e modo de vida sempre esteve associado aos espaços costeiro-marinhos, as mudanças que ocorrem nesses ambientes são percebidas de maneira nítida (ADAMS, 2000; DIEGUES, 2004a; PERES et al., 2016). No Araçá, a percepção de que a pesca "diminuiu" em relação a décadas passadas devido, principalmente, ao desenvolvimento das atividades portuária e petrolífera na região, foi unanime a todos os pescadores entrevistados. A sombra de uma nova proposta de expansão do porto (apresentada em 2011) também foi citada como uma grande ameaça a pesca artesanal nesse território, visto que implicaria na perda de uma grande área da baía (PERES et al., 2016). Assim, caso essa ampliação ocorra, muitos afirmaram que a pesca vai "acabar por completo", o que os levará, ou a abandonar a atividade, ou a mudar de região.

Nenhum pescador entrevistado reconheceu a existência de regras formais que "regem" a atividade pesqueira no Araçá, no entanto, afirmaram existir o ética do respeito, do bom senso e da camaradagem em relação aos demais. Embora esses elementos não sejam vistos como regras formalizadas, os mesmos podem ser entendidos como parte de um "código de honra" que representam os mecanismos informais de apropriação desse território pelos pescadores, de forma similar ao que relatou CORDELL (2001) para a pesca de calão no litoral sul do estado da Bahia. O respeito ao período reprodutivo das espécies ao não capturar juvenis e fêmeas ovadas e o uso da estratégia do segredo para não revelar os locais onde sabem que há concentração de cardumes também fazem parte desses mecanismos informais dos pescadores 
do Araçá, que contribuem para minimizar conflitos e assegurar a conservação dos espaços e recursos naturais locais, bem como a continuidade da pesca artesanal e de seu modo de vida tradicional.

Ao considerar a possibilidade de criação de áreas fechadas ou de proibição da pesca, a maioria dos pescadores acredita que não há essa necessidade. Para eles, o ideal seria reduzir/corrigir os problemas que afetam a região, principalmente atrelados a poluição, pois o ambiente local é capaz de sustentar a pesca nos moldes e escala atuais, sem comprometer o futuro da atividade e gerar impactos negativos significativos sobre a biota marinha. Por outro lado, os pescadores afirmaram que seriam a favor de algumas medidas restritivas como, por exemplo, a proibição do arrastão e da pesca por atuneiros (barcos industriais), pois ambas tem um grande impacto sobre o ambiente local.

Os resultados apresentados corroboram com a hipótese de que existem pescadores artesanais (caiçaras) que usam a região da Baía do Araçá como seu território tradicional de pesca. Assim, o CT desses pescadores e seus mecanismos de apropriação dos espaços e recursos naturais costeiromarinhos estão intimamente ligados essa região. A perda desse território, como no caso de uma eventual ampliação do Porto de São Sebastião, poderia resultar no fim da pesca artesanal, do modo de vida, das práticas e do conhecimento tradicional caiçara na Baía do Araçá, o que seria uma perda inestimável.

Conforme apresentado anteriormente, a Baía do Araçá possui características únicas e compreende diversos tipos de habitats (como manguezais, costões, praias e parcéis submersos), que a tornam capaz de abrigar/suportar uma elevada biodiversidade sendo vista por pesquisadores como um verdadeiro "laboratório natural" (AMARAL et al., 2010; 2015). Enquanto beneficiários diretos dessa "riqueza ecológica" e possuidores de um amplo CT a respeito do funcionamento desse território, os pescadores entrevistados reconhecem a importância ecológica do Araçá e o papel dessa região enquanto um "viveiro", "criadouro", "berçário", que se configura como um verdadeiro "santuário" de biodiversidade e que "tem tudo quanto é espécie". Para eles, inúmeras espécies da fauna marinha procuram o local 
para se reproduzir, se alimentar e se desenvolver devido a fatores como: a heterogeneidade de habitas, a ampla disponibilidade de alimentos, e o fato de o local ser um "remanso" e oferecer uma certa proteção contra predadores. Em uma publicação recente sobre a área, intitulada "A vida na Baía do Araçá", AMARAL et al. (2015) também ressaltam esse papel da baía enquanto um "berçário" e apresentam resultados que confirmam esse raciocínio apresentado pelos pescadores.

Ao investigar o CT dos entrevistados a respeito das etnoespécies (principalmente as que são mais utilizadas/capturadas), observou-se que esses pescadores identificam diversos padrões e características, ligadas a questões como a sazonalidade e os hábitos e habitats preferenciais de ocorrência (distribuição espacial). Em relação a sazonalidade, os pescadores classificam as etnoespécies entre aquelas que são frequentes e abundantes durante o "ano todo" e aquelas que ocorrem predominantemente durante o "verão" ou "inverno", utilizando o mesmo modelo de classificação observado por RAMIRES et al., (2007) em comunidades caiçaras do Litoral Sul do Estado de São Paulo. A distribuição espacial das espécies obedecem padrões comparáveis aos modelos de "zonas ecológicas" abordadas por POSEY (1987). Tais "modelos" evidenciam um conjunto de conhecimentos que os pescadores do Araçá possuem a respeito tanto dos ambientes submersos, quanto dos hábitos e preferências das etnoespécies (p.ex.: comportamentos de migração e predação, e locais e tipos de alimentação).

Para os principais invertebrados capturados no Araçá, os pescadores apontaram fatores como a disponibilidade de alimentos e, principalmente, 0 "tipo de fundo" que cada espécie de invertebrado "gosta" (p.ex.: pedra, cascalho, areia, lama), como as principais informações relevantes para identificar os locais de distribuição preferencial dessas espécies. Estudos sobre invertebrados bentônicos na região também apontam que a composição do substrato ou "tipo de fundo" é um dos principais fatores que regem a distribuição desses organismos (AMARAL et al., 2015), o que evidencia uma similaridade entre CT e científico.

Para os peixes, um exemplo dos padrões identificados é o dos peixes de passagem (p.ex.: carapau, anchova, sororoca e espada) que "são de fora", 
"entram por essas beiradas" e "vêm atrás da sardinha, do camarão". ARANTES (2014) realizou um levantamento da dieta de 23 espécies (algumas das quais mencionadas pelos pescadores) e seus resultados se aproximam do CT dos pescadores entrevistados sobre o comportamento alimentar espécies como o espada (Trachiurus lepturus) e o robalo (Centropomus parallelus, Centropomus undecimalis) que, segundo ambos, são predadores e se alimentam, predominantemente, de peixes menores ou de camarões.

Com relação a distribuição espacial dos peixes, estudos na literatura sobre esse tema são raros considerando a escala espacial abordada (de poucos $\mathrm{km}^{2}$ ). A identificação desses aspectos através do CT é um exemplo que ilustra uma possibilidade de aplicação dessas bases de conhecimento, enquanto fonte de informações para a gestão integrada, na ausência ou carência de dados científicos.

A compreensão de fenômenos físico-oceanográficos atrelados as condições do mar e do tempo, também é essencial para o sucesso na pesca (MALDONADO, 2000). No Araçá. um fenômeno de grande relevância citado pelos pescadores, são as chamadas "águas de sul" e "águas de leste". Além de serem diferenciadas pelo sentido/direção de "onde vem" (em relação ao Canal de São Sebastião), esses regimes de águas também são diferenciados por apresentar condições físico-químicas distintas, que influenciam nos tipos de espécies capturadas. Num estudo sobre a hidrografia e a circulação do Canal de São Sebastião, CASTRO et al. (2008) identificaram processos de alternância no sentido das correntes superficiais locais, que correspondem de forma muito próxima aos regimes de circulação descritas pelos pescadores. Tal correspondência demonstra que, pelo menos em termos qualitativos, O CT e o conhecimento científico a respeito desses processos são convergentes.

Outro fenômeno que foi mencionado pelos pescadores foi a chamada "revessa de maré", movimento de rotação das águas no interior da baía que ocorre atrelado a subida da maré e de entrada de águas provenientes do Canal de São Sebastião. Embora a revessa não influencie diretamente na pesca, segundo os próprios pescadores, ela é reconhecida por "trazer o lixo" e por reter "a lama" que depositam nas praias e manguezais nas margens do lado oeste da baía. Ao investigar mudanças nos processos hidrográficos da área 
interna da baía devido a expansão do Porto de São Sebastião, VILLAMARIN (2014) sugere que atualmente há uma "menor renovação das águas e acúmulo de sedimentos na porção esquerda (lado oeste da baía)". Mesmo que tal afirmação não se refira diretamente ao processo de rotação das águas, ela vai ao encontro das observações realizadas pelos pescadores sobre a deposição de resíduos nessa mesma região.

A partir dos resultados apresentados, observou-se que, de modo geral, o CT dos pescadores entrevistados forneceu um amplo conjunto de informações sobre o território do Araçá atrelado tanto a aspectos ecológicos/biológicos (envolvendo a fauna marinha, seus comportamento e habitats) quanto a aspectos físico-oceanográficos (relacionados as correntes e variação das marés) desse ambiente costeiro-marinho. Embora tais informações tenham sido apresentadas de forma compartimentada nas análises dessa pesquisa, a principal característica do CT investigado é o fato de que o mesmo reflete uma visão holística, integrada e ecossistêmica sendo, também, adaptativo por natureza (BERKES et al., 1995; 2000; DIEGUES, 2003). A constante interpretação e reinterpretação dessas características/ fatores permite que os pescadores identifiquem padrões e peculiaridades das espécies-alvo que pretendem capturar, os quais são utilizados em favor da pesca. Desse modo, esse conjunto de conhecimentos é considerado fundamental para o sucesso das comunidades tradicionais pesqueiras (RUDDLE, 2000; CORDELL, 2001; DIEGUES, 2004b; RAMIRES et al., 2007).

É interessante notar que, geralmente, quando comparado à literatura científica, o CT registrado apresenta diversas similaridades. $O$ fato de parte desses saberes tradicionais serem confirmados demonstra a convergência que existe entre ambas as formas de conhecimento, corroborando para o uso do CT enquanto uma fonte de dados complementar em processos de gestão integrada. No entanto, em muitos casos as informações fornecidas pelo CT são inéditas devido a uma ausência ou carência de dados científicos. Nesses casos, desde que sejam devidamente investigados e sistematizados, os saberes tradicionais podem aportar informações que podem ser tanto primárias quanto complementares ao conhecimento científico, preenchendo lacunas e contribuindo com processos de planejamento e gestão. 
O complexo ecossistema costeiro-marinho da Baía do Araçá fornece uma série de serviços e benefícios à comunidade local como um todo (CARRILHO, 2015; TURRA et al., 2015, PLDS/Araçá, 2016). Para pescadores, que possuem uma forte ligação sociocultural com esse território, tal espaço é fundamental e lhes garante a manutenção de seu modo de vida tradicional. Pautados nessa relação íntima com o território e no conhecimento que possuem dele, os pescadores mencionaram diversas importâncias/pontos positivos (p.ex.: fornecimento de alimento e renda; identidade cultural; biodiversidade; desenvolvimento de atividades científicas e educacionais; e saúde/tranquilidade) e problemas/pontos negativos (p.ex.: poluição por resíduos sólidos e descargas de esgoto; surgimento de novas indústrias; e desamparo do poder público) atreladas à região. Essas importâncias e problemas são aspectos fundamentais do ponto de vista do planejamento estratégico, uma vez que refletem o cenário atual de um determinado local, devendo ser consideradas em processos de gestão local (BUARQUE, 2008).

Ao refletir sobre o futuro, a preocupação com a melhoria das condições ambientais e com a preservação/conservação da biodiversidade marinha na baía ficaram evidentes nos discursos dos entrevistados, sendo compartilhada por todos. Com base no conhecimento natural e social dos entrevistados a cerca do Araçá, ações como melhorar as condições de infraestrutura urbana; desenvolver ações visando a manutenção da tradição da pesca artesanal; e incentivar o uso da baía como um local de pesquisas e visitação turística foram propostas como solução para problemas e catalisadoras do futuro almejado. Ações nesse âmbito deveriam ser consideradas em processos de planejamento e tomada de decisão, uma vez que consideram o CT e as opiniões daqueles que serão afetados diretamente por elas (TRAN et al., 2002; JUNG et al., 2011; TAYLOR et al., 2011). Desse modo, as decisões teriam um caráter mais democrático e inclusivo, minimizando conflitos e promovendo sinergias locais (SOUSA et al., 2013).

$\mathrm{Na}$ análise SWOT pautada no CT dos pescadores do Araçá, foram identificadas potencialidades como segurança, beleza cênica, pesca artesanal e biodiversidade; oportunidades como o desenvolvimento do turismo comunitário, a despoluição dos córregos que deságuam na baía e o 
fortalecimento da participação social; fraquezas como a presença de resíduos sólidos, presença de esgoto e falta de iluminação nas áreas de acesso a baía; e ameaças como o crescimento urbano desordenado, o tráfego intenso de embarcações e o descaso do poder público pela região. Ao identificar de forma clara e simples fatores internos e externos que influenciam positivamente ou negativamente o território local, tal ferramenta facilita a definição e priorização de ações que podem catalisar as potencialidades e oportunidades, e minimizar ou evitar as fragilidades e ameaças, visando a sustentabilidade da região (BUARQUE, 2008; VIEGAS et al.,2014; BRAUN; AMORIM, 2014). Os resultados apresentados no SWOT/Araçá demonstram que o CT pode ser direcionado para questões focais atreladas ao planejamento estratégico e, assim, auxiliar na tomada de decisão sobre a região do Araçá.

Do mesmo modo que no SWOT/Araçá, os resultados apresentados no DPSIR/Araçá refletem os saberes/percepções dos pescadores do Araçá sobre o ambiente local, exemplificando relações de causa e efeito relacionadas aos problemas locais de forma simples e concisa, bem como algumas possibilidades de respostas/ações para enfrentá-los. Um exemplo claro que foi abordado pelos pescadores e contemplado no DPSIR é o da poluição por esgoto doméstico irregular (pressão). Conforme apontado pelos pescadores, tal pressão é originada pelo crescimento urbano desordenado da região e pelo aumento das ocupações irregulares (fator indutor de mudanças). Como consequências dessa pressão ocorrem alterações do estado do ambiente, como acúmulo de matéria orgânica, e impactos como a redução da qualidade da água. Assim, em resposta a essas mudanças que ocorreram, os entrevistados mencionaram que são necessárias ações como a ampliação da infraestrutura pública de saneamento básico. A aplicação do DPSIR, permite comunicar com clareza as relações entre origens e consequências dos problemas abordados e, de uma forma pragmática, definir sobre quais "fatores" devem ser concentradas as ações visando a solução ou mitigação do problema em questão (GABRIELSEN; BOSCH, 2003; ATKINS et al., 2011; XAVIER; TURRA, 2013). Cabe ressaltar que tais resultados derivaram de um exercício de interpretação e sistematização das informações registradas nas entrevistas com os pescadores, e que os mesmos podem ser complementados com 
informações e dados provenientes de outras bases como relatórios de programas de monitoramento e/ou publicações científicas sobre a região. Além disso, as respostas/ações frente as mudanças que foram sugeridas, são exemplos que se baseiam numa perspectiva de futuro partilhada pelos pescadores, mas que não foram discutidas em profundidade para que se pudesse avaliar questões como a efetividade e a viabilidade dessas propostas. 


\section{CONSIDERAÇÕES FINAIS}

Os resultados apresentados e discutidos nesse trabalho confirmam a hipótese de que existem pescadores artesanais caiçaras que usam a região Baía do Araçá como seu território tradicional de pesca. Esses pescadores possuem formas próprias de apropriação desse território, pautado em um amplo conjunto de saberes e práticas tradicionais, além de condutas (regras informais) que são partilhadas entre eles. Assim, a conservação e preservação desses territórios tradicionais, assim como a Baía do Araçá, são consideradas aspectos fundamentais para a manutenção da identidade e do modo de vida das comunidades caiçaras (BEGOSSI, 1998; ADAMS, 2000a; CASTRO, 2000; DIEGUES, 2004a; 2008).

Esse conjunto de saberes tradicionais dos pescadores do Araçá sobre o território no/do qual vivem é pautado numa perspectiva holística, integrada e ecossistêmica, de caráter adaptativo/dinâmico, tendo sido adquirido e aperfeiçoado através da prática da pesca; do aprender "vendo/fazendo"; da transmissão de saberes patrimoniais pelos "mais velhos"; e do aprendizado contínuo associado aos processos de percepção sensorial e cognitiva inerentes das relações entre homem-mar, que esses pescadores desenvolveram. Verificou-se, por exemplo, um amplo conhecimento dos pescadores em relação ao zoneamento dos diversos habitats que Baía do Araçá possui e tais resultados podem contribuir no processo de formulação de políticas de ordenamento. Assim, no contexto da gestão integrada, esse conjunto de saberes tradicionais pode fornecer um grande valor para 0 desenvolvimento de estratégias de gestão local, pois além de incorporar diversas informações sobre o funcionamento do território, consideram suas opiniões, valores e percepções (HILL et al., 2010; MOURA et al., 2013; NARCHI et al., 2014; RAMIRES et al., 2015).

Nesse contexto, o uso de modelos como o SWOT e o DPSIR facilitou a organização das informações registradas e seu direcionamento para a definição de ações estratégicas que visem o desenvolvimento sustentável da região. Embora esses modelos sejam aplicados recorrentemente no âmbito da gestão e do planejamento ambiental, o uso do CT tradicional enquanto uma base primária de informações para subsidiar tais modelos ainda é uma questão 
muito pouco explorada. Nesse contexto, os resultados do SWOT/Araçá e DPSIR/Araçá, demonstram o potencial de aplicação do CT como uma das bases de dados que podem fomentar a construção desses modelos.

Com base nos resultados obtidos nesse trabalho, considera-se que processos de planejamento, tomada de decisão e gestão dos espaços e recursos costeiro-marinhos, devem levar em consideração as peculiaridades socioculturais existentes nessas regiões e incluir os pescadores e seu CT, de forma colaborativa e democrática. 


\section{REFERÊNCIAS}

ABUCHAHLA, G. M. O. 2009. Community-based ICZM in the context of climate change: a case study of Keezhathottam village, Tamil Nadu, Southern India. Kiel: Christian-Albrechts-Universität zu Kiel.

ADAMS, C. 1998. Caiçaras na Mata Atlântica: Pesquisa científica versus planejamento e gestão ambiental. In: VEIGA, J. E. (Org.). Cência Ambiental: Primeiros Mestrados. São Paulo: Annablume. p. 299 - 320.

ADAMS, C. 2000a. Caiçaras na Mata Atlântica: pesquisa científica versus planejamento e gestão ambiental. [1a. Ed]. São Paulo: Annablume, 336p.

ADAMS, C. 2000b. As populações caiçaras e o mito do bom selvagem: a necessidade de uma nova abordagem multidisciplinar. Revista de Antropologia, v. 43, p. 145-181.

AFONSO, C. M. 1998. Uso e ocupação do solo na zona costeira do estado de São Paulo: Uma análise ambiental. In: VEIGA, Z. E. (Org.). Ciência ambiental: Primeiros mestrados. São Paulo: Annablume, p. 277-299.

ALBUQUERQUE, E. C. 2013. Considerações sobre os impactos ambientais negativos previstos sobre a Baía do Araçá devido à ampliação do Porto de São Sebastião: um olhar da engenharia sobre o meio ambiente marinho. Dissertação. São Paulo. Programa de Pós-graduação em Ciências Ambientais, Universidade de São Paulo, 124pp.

ALLUT, A. G. 2000. O conhecimento dos especialistas e seu papel no desenho de novas políticas pesqueiras. In: DIEGUES, A. C. (Org.) Etnoconservação. São Paulo: Annablume, p. 101-124.

AMARAL, A. C. Z.; MIGOTTO, A.; TURRA, A.; SCHAEFFER-NOVELLI, Y. 2010. Araçá: biodiversidade, impactos e ameaças. Biota Neotropica, v. 10, p. 219-264.

AMARAL, A. C. Z.; TURRA, A.; CIOTTI, A. M.; WONGTSCHOWSKI, C. L. D. B. R.; SCHAEFFER-NOVELLI, Y. 2015. Vida na Baía do Araçá: Diversidade e importância. São Paulo: LUME, 100 pp.

AMARAL, A. C. Z.; SCHAEFFER-NOVELLI, Y.; ROSSI-WONGTSCHOWSKI, C. D.; CIOTTI, Á. M.; TURRA, A.; SIEGLE, E.; ALCANTARA, J.; SOARES, L. S.; ÁVILA DA SILVA, A. O.; SINISGALLI, P. A.; ANGELINI, R.; CONTI, L. A. 2016. Biodiversity and functioning of a subtropical coastal ecosystem: a 
contribution to an integrated managment. XIX Iberian Symposium on Marine Biology Studies. doi: 10.3389/conf.FMARS.2016.05.00005

ARANTES, L. P. L. 2014. Relações alimentares de peixes da Enseada do Araçá (SP), Sudeste do Brasil. Dissertação. São Paulo. Programa de Pósgraduação em Oceanografia, Universidade de São Paulo, 196pp.

ARKEMA, K. K.; ABRAMSON, S. C.; DEWSBURY, B. M. 2006. Marine ecosystem-based management: from characterization to implementation. Frontiers in Ecology and the Environment, v. 4, p. 525-532.

ARMITAGE, D. 2005. Adaptive capacity and community-based natural resource management. Environmental management, v. 35, p. 703-15.

ARRUDA, R. S. V. 2000. "Populações Tradicionais" e a proteção dos recursos naturais em Unidades de Conservação. In: DIEGUES, A. C. (Org.). Etnoconservação: Novos rumos para a proteção da naturea nor trópicos. São Paulo: Annablume, p. 273 - 290.

ASMUS, M. L.; KITZMANN, D.; LAYDNER, C.; TAGLIANI, C. R. A. 2006. Gestão costeira no Brasil: Instrumentos, fragilidades e potencialidades. Gerenciamento Costeiro Integrado, v. 4, p. 52-57.

ATKINS, J. P; BURDON, D.; ELLIOT, M.; GREGORY, A. 2011. Management of the marine environment: integrating ecosystem services and societal benefits with the DPSIR framework in a systems approach. Marine pollution bulletin, v. 62, p. 215-26.

ÁVILA-DA-SILVA, A. O.; CARNEIRO, M. H.; SAKAMOTO, M. S. 2015. Atividade pesqueira: suporte à vida no mar e ao pescador. In: AMARAL, A. C. Z.; TURRA, A.; CIOTTI, A. M.; WONGTSCHOWSKI, C. L. D. B. R.; SCHAEFFER-NOVELLI, Y. Vida na Baía do Araçá: Diversidade e importância. São Paulo: LUME, p. 79-88.

BARBIER, E. B.; KOCH, E.; SILLIMAN, B.; HACKER, S.; WOLANSKI, E.; PRIMAREVA, J.; GRANEK, E.; POLASKY, S.; ASWANI, S.; CRAMER, L.; STOMS, D.; KENNEDY, C.; BAEL, D.; KAPPEL, C.; PERILLO, G.; REED, D. 2008. Coastal ecosystem-based management with nonlinear ecological functions and values. Science, v. 319, p. 321-3.

BEAUMONT, N.; AUSTEN, M.; MANGI, S.; TOWNSEND, M. 2008. Economic valuation for the conservation of marine biodiversity. Marine pollution 
bulletin, v. 56, p. 386-96.

BEGOSSI, A. 1998. Cultural and ecological resilience among caiçaras of the Atlantic Forest and caboclos of the Amazon, Brazil. In: BERKES, F.; FOLKE, C. (Eds.). Linking social and cultural systems for resilience.

Cambridge: Cambridge University Press, p. 129-157.

BEGOSSI, A. 2000. Resilience and neo-traditional populations: the caiçaras (Atlantic Forest) and caboclos (Amazon, Brazil). In: BERKES, F.; FOLKE, C.; COLDING, J. Linking social and ecological systems: Management practices and social mechanisms for building resilience. Cambridge: Cambridge University Press, p. 129-157.

BELCHIOR, C. C. 2008. Gestão Costeira Integrada - Estudo de Caso do Projeto ECOMANAGE na Região Estuarina de Santos - São Vicente, SP, Brasil. São Paulo: Universidade de São Paulo.

BERKES, F.; FOLKE, C.; GADGIL, M. 1995. Traditional ecological knowledge, biodiversity, resilience and sustainability. In: PERRINGS, C. A.; MÄLER, K.; FOLKE, C.; HOLLING, C.; JANSSON, B. (Eds.). Biodiversity Conservation: Problems and policies. Ecology, Economy and Environment, [s.I.]: Springer Netherlands, p. 281-299.

BERKES, F.; COLDING, J.; FOLKE, C. 2000. Rediscovery of traditional ecological knowledge as adaptive management. Ecological applications, $\mathrm{v}$. 10 , p. $1251-1262$.

BERKES, F. 2004. Rethinking Community-Based Conservation. Conservation Biology, v. 18, p. 621-630.

BIDONE, E. D.; LACERDA, L.D. 2004. The use of DPSIR framework to evaluate sustainability in coastal areas. Case study: Guanabara Bay basin, Rio de Janeiro, Brazil. Regional Environmental Change 4, 5e16.

BIJLSMA, L.; EHLER, C.; KLEIN, R.; KULSHRESTHA, S.; MCLEAN, R.; MIMURA, N.; NICHOLLS R.; NURSE L.; NIETO H.; STAKHIV E.; TURNER R.; WARRICK R. 1995. Coastal zones and small islands. Em: Climate Change 1995: Impacts, Adaptations and Mitigation of Climate Change Scientific-Technical Analyses. Cambridge: Cambridge University Press, $p$. 289-324.

BONI, V.; QUARESMA, S. J. 2005. Aprendendo a entrevistar: como fazer 
entrevistas em ciências sociais. Revista Eletrônica dos Pós-Graduandos em Sociologia Política da UFSC, v. 2, p. 68-80.

BOWEN, R. E.; RILEY, C. 2003. Socio-economic indicators and integrated coastal management. Ocean \& Coastal Management, v. 46, p. 299-312.

BRASIL. Decreto № 6.040, de 7 de fevereiro de 2007. Institui a Política Nacional de Desenvolvimento Sustentável dos Povos e Comunidades Tradicionais. Diário Oficial de União, Brasília (2007 fev 08); 316 pp.

BRAUN, R.; AMORIM, A. 2014. Rapid SWOT diagnosis method for Conservation Areas. Scottish Geographic Journal, p. 1-19. Disponível em: $<$ https://drive.google.com/drive/folders/0B9DaOsy3mMMjT3BjMVk5d1JNRz g>. Acessado em: Outubro 2014.

BUARQUE, S. C. 2008. Construindo o desenvolvimento local sustentável: metodologia de planejamento. Rio de Janeiro: Editora Garamond, 177pp.

BURKE, L.; KURA, Y.; KASEM, K.; REVENGA, C.; SPALDING, M.; MCALLISTER, D. 2001. Pilot analysis of global ecosystems: Coastal ecosystems. Washington, D.C.: World Resources Institute, 77pp.

CAMPOS, M. D. O. 2002. Etnociência ou etnografia de saberes, técnicas e práticas?. In: AMOROZO, M. C. M.; MING, L. C.; SILVA, S. P. (Eds). Métodos de coleta e análise de dados em etnobiologia, etnoecologia e disciplinas correlatas. Rio Claro: UNESP/CNPq, p. 47-92.

CAPUCCI, M. R. 2016. Aspectos fundiários das comunidades caiçaras. In: NETO, P. S. (Org.). Direito das comunidades tradicionais. São Paulo: Café com lei, p. 105-132.

CARLSSON, L.; BERKES, F. 2005. Co-management: concepts and methodological implications. Journal of environmental management, v. 75, p.65-76.

CARR, E. R.; WINGARD, P.; YORYT, S.; THOMPSON, M.; JENSEN, N. 2007. Applying DPSIR to sustainable development. International Journal of Sustaineble Development \& World Ecology, v. 14, p. 543-555.

CARRILHO, C. D. 2015. Identificação e valoração econômica e sociocultural dos serviços ecossistêmicos da Baía do Araçá - São Sebastão, SP, Brasil. Dissertação. São Paulo. Programa de Pós-graduação em Ciências Ambientais, Universidade de São Paulo, 170pp. 
CARVALHO, H. C. B. 2001. Artesanato de caixeta em São Sebastião - SP. 143p. Dissertação. Piracicaba. Programa de Pós-graduação em Ciências Florestais, Universidade de São Paulo, 143pp.

CASTRO, E. 2000. Território, biodiversidade e saberes. In: DIEGUES, A. C. (Org.). Etnoconservação: Novos rumos para a proteção da naturea nor trópicos. São Paulo: Annablume, p. 165-182.

CASTRO, B. M.; MIRANDA, L. B.; SILVA, L. S., FONTES, R. F. C. 2008. Processos físicos: Hidrografia, Circulação e Transporte. In: PIRES-VANIN, A. M. S (Org.). Oceanografia de um Ecossistema Subtropical: Plataforma de São Sebastião, SP. São Paulo: Editora da Universidade de São Paulo, p. 59-122.

CHRISTIE, P. 2011. Creating space for interdisciplinary marine and coastal research: five dilemmas and suggested resolutions. Environmental Conservation, v. 38, p. 172-186.

CICIN-SAIN, B. 1993. Sustainable Development and Integrated Coastal Management. Ocean \& Coastal Management, v. 21, p. 11-43.

CICIN-SAIN, B.; KNECHT, R. W.; FISK, G. W. 1995. Growth in capacity for integrated coastal management since UNCED: as international perspective. Ocean \& Coastal Management, v. 29, p. 93-123.

CICIN-SAIN, B.; KNECHT, R. W. 1998. Integrated Coastal and Ocean Management: Concepts And Practices. [s.I.]: Island Press, 517 pp.

CICIN-SAIN, B.; BELFIORE, S. 2005. Linking marine protected areas to integrated coastal and ocean management: A review of theory and practice. Ocean \& Coastal Management, v. 48, p. 847-868.

CLARK, J. R. 1992. Integrated management of coastal zones. FAO Fisheries Technical Paper, № 327. Roma: FAO, 167pp.

CLARK, J. R. 1997. Coastal zone management for the new century. Ocean \& Coastal Management, v. 37, p. 191-216.

CLAUZET, M.; BARRELA, W. 2004. A pesca artesanal na Praia Grande do Bonete, Ubatuba, litoral norte de São Paulo. In: DIEGUES, A. C. (Org.). Encoclopédia Caiçara: $O$ olhar do pesquisador. São Paulo: Editora HUCITEC-NUPAUB, p. 149-162.

CMMAD (COMISSÃO MUNDIAL SOBRE MEIO AMBIENTE E 
DESENVOLVIMENTO). 1991. Nosso futuro comum. [2a Ed] Rio de Janeiro: Editora Fundação Getúlio Vargas, 430pp.

CORDELL, J. 2001. Marginalidade social e apropriação territorial marítima na Bahia. In: DIEGUES, A. C.; MOREIRA, A. C. C. (Org.). Espaços e Recursos Naturais de Uso Comum. São Paulo: NUPAUB-USP, p. 139-162. COSTA, W. M. 2005. Subsídios para uma Política Nacional de Ordenamento Territorial. In: Ministério da Integração Nacional (MIN). Para pensar uma política nacional de ordenamento territorial: anais da Oficina sobre a Política Nacional de Ordenamento Territorial. Brasília: MI, pp. 55-59.

COWX, I. G.; ARLINGHAUS, R.; COOKE, S. J. 2010. Harmonizing recreational fisheries and conservation objectives for aquatic biodiversity in inland waters. Journal of Fish Biology, v. 76, p. 2194-2215.

CROSSLAND, C.; BAIRD, D. 2005. The coastal zone - a domain of global Interactions. Em: Coastal Fluxes in the Anthropocene. Global Change The IGBP Series. [s.I.]: Springer Berlin Heidelberg, p. 1-37.

CUMMING, G. S.; CUMMING, D. H. M.; REDMAN, C. L. 2006. Scale mismatches in social-ecological systems: causes, consequences, and solutions. Ecology and Society, v. 11, p.14.

CUNHA, L. H. O. 2000. Tempo natural e tempo mercantil na pesca artesanal. Em: DIEGUES, A. C. (Org.). A Imagem das Águas. São Paulo: Hucitec, p. 101-110.

CUNHA, I. 2003. Conflito ambiental em águas costeiras: Relação porto-cidade no Canal de São Sebastião. Ambiente \& sociedade, vol. 6, p. 83-98.

CURTIN, R.; PRELLEZO, R. 2010. Understanding marine ecosystem based management: A literature review. Marine Policy, v. 34, p. 821-830.

DENADAI, M. R.; GONÇALVES, M. A. O.; OlIVATO, D.; TURRA, A. 2009. Com quantas memórias se faz uma canoa. São Paulo: Instituto Costa Brasilis, $250 \mathrm{pp}$.

DIEGUES, A. C. 1983. Pescadores, camponeses e trabalhadores do mar. São Paulo: Ed. Ática, $287 \mathrm{pp}$.

DIEGUES, A. C.; NOGARA, P. J. 1999. O nosso lugar virou parque. [2a Ed.]. São Paulo: NUPAUB, 165 pp.

DIEGUES. A. C. 2000. Etno-conservação da natureza: enfoques alternativos. 
In: DIEGUES, A. C. (org.). Etnoconservação: novos rumos para a proteção da natureza nos trópicos. [2a. Ed.] São Paulo: Annablume, p. 1-46.

DIEGUES, A. C. 2003. Sociedades e comunidades sustentáveis. São Paulo: NUPAUB/USP, p. 1-7.

DIEGUES, A. C. (Org.) 2004a. Encoclopédia Caiçara: O olhar do pesquisador. São Paulo: Editora HUCITEC-NUPAUB, 382 pp.

DIEGUES, A. C. 2004b. Conhecimento tradicional e apropriação social do ambiente marinho. In: DIEGUES, A. (Org.). A pesca construindo sociedades. São Paulo: NUPAUB, p. 1-18.

DIEGUES, A. 2004b. A pesca construindo sociedades. São Paulo: NUPAUB USP, $315 \mathrm{pp}$.

DIEGUES, A. 2008. O Mito Moderno da Natureza Intocada. [3a Ed.] São Paulo: Editora Hucitec, $169 \mathrm{pp}$.

EDWARDS, S. D.; JONES, P.; NOWELL, D. 1997. Participation in coastal zone management initiatives: a review and analysis of examples from the UK. Ocean \& Coastal Management, v. 36, p. 143-165.

ELLSWORTH, J. E.; HILDEBRAND, L.; GLOVER, E. 1997. Canada's Atlantic Coastal Action Program: A community-based approach to collective governance. Ocean \& Coastal Management, v. 36, p. 121-142.

ERNANDORENA, P. R. A ação civil pública e a resolução dos conflitos ambientais em zona costeira de Santa Catarina. [s.l: s.n.].

FARIA, A. A. DA C.; NETO, P. S. F. 2006. Ferramentas de Diálogo Qualificando o Uso das Técnicas de DRP: Diagnóstico Rural Participativo. [2a Ed.] Brasília: IEB (Instituto Internacional de Educação do Brasil), 76 pp.

FEENY, D.; BERKES, F.; MACCAY, B. J.; ACHESON, J. M. 2001. A tragédia dos comuns: Vinte e dois anos depois. In: DIEGUES, A. C.; MOREIRA, A. C. C. (Org.). Espaços e Recursos Naturais de Uso Comum. São Paulo: NUPAUB-USP, p. 17 - 42.

FOLKE, C.; HAHN, T.; OLSSON, P.; NORBERG, L. 2005. Adaptive Governance of Social-Ecological Systems. Annual Review of Environment and Resources, v. 30, p. 441-473.

GABRIELSEN, P.; BOSCH, P. (Org.). 2003. Environmental Indicators: Typology and Use in Reporting. European Environment Agency, 20 pp. 
GADGIL, M.; BERKES, F.; FOLKE, C. 1993. Indigenous knowledge for biodiversity conservation. Ambio, v. 22, p. 151-156.

GARI, S. R.; NEWTON, A.; ICELY, J. D. 2015. A review of the application and evolution of the DIPSIR framework with an emphasis on coastal socialecological systems. Ocean \& Coastal Management, v. 103, p. 63-77.

GESAMP (IMO/FAO/UNESCO-IOC/WMO/WHO/IAEA/UN/UNEP JOINT GROUP OF EXPERTS ON THE SIENTIFIC ASPECTS OF MARINE ENVIRONMENTAL PROTECTION). 1996. The Contributions of Science to Integrated Coastal Management (FAO, Ed.): Reports an studies. Rome: FAO.

Disponível

em:

$<$ http://books.google.com/books?hl=en\&lr=\&id=QMIIMa0S0I4C\&oi=fnd\&pg= PA1\&dq $=$ The +contributions + of + science+to+integrated + coastal+manageme nt\&ots=LxaNXOLBai\&sig=udbUPC3hpelO38hbXWpPQUCsGUl>. Acesso em: 13 ago. 2014.

GIL, A. C. 1989. Métodos e técnicas de pesquisa social. [2a Ed.] São Carlos: Editora Atlas S.A., 206 pp.

GIUPPONI, C.; FASSIO, A.; FEÁS VÀZQUEZ, F.; MYSIAK, J. 2006. Sustainable water management and policy making. In: GIUPPONI, C., JAKEMAN, A. J.; KARSSENBERG, D.; HARE, M. P. (Eds.). Sustainable Management of Water Resources - An Integrated Approach. Northampton: Edward Elgar Publishing, p. 71-97.

GODELIER, M. 1984. L'approproation de la nature. In: GODELIER, M. L'idéel et le matériel: Pensée, économies, sociétés. Paris: Fayard, p. 112-117.

GRABNER, M. L. 2016. Os caiçaras e as Unidades de Conservação de Proteção Integral: Convergência entre os direitos fundamentais das comunidades tradicionais e a conservação ambiental. In: NETO, P. S. (Org.). Direito das comunidades tradicionais. São Paulo: Café com lei, p. 65 $-104$.

HALPERN, B. S.; WALBRIDGE, S.; SELKOE, K. A; KAPPEL, C. V.; MICHELI, F.; D'AGROSA, C.; BRUNO, J. F.; CASEY, K. S.; EBERT, C.; FOX, H. E.; FUJITA, R.; HEINEMANN, D.; LENIHAN, H. S.; MADIN, E. M. P.; PERRY, M. T.; SELIG, E. R.; SPALDING, M.; STENECK, R.; WATSON, R. 2008. A global map of human impact on marine ecosystems. Science, v. 319, p. 
$948 \mathrm{e} 952$.

HALPERN, B. S.; LONGO, C.; HARDY, D.; MCLEOD, K. L.; SAMHOURI, J. F.; KATONA, S. K.; KLEISNER, K.; LESTER, S. E.; O'LEARY, J.; RANELlETTI, M.; ROSENBERG, A. A.; SCARBOROUGH, C.; SELIG, E. R.; BEST, B. D.; BRUMBAUGH, D. R.; CHAPIN, F. S.; CROWDER, L. B.; DALY, K. L.; DONEY, S. C.; ELFES, C.; FOGARTY, M. J.; GAINES, S. D.; JACOBSEN, K. I.; KARRER, L. B.; LESLIE, H. M.; NEELEY, E.; PAULY, D.; POLASKY, S.; RIS, B.; ST MARTIN, K.; STONE, G. S.; SUMAILA, U. R.; ZELLER, D. 2012. An index to assess the health and benefits of the global ocean. Nature, v. 488, p. $615 \mathrm{e} 620$.

HEGARTY, A. 1997. Start with what the people know: a community based approach to integrated coastal zone management. Ocean \& Coastal Management, vol. 36, p. 167-203.

HILDEBRAND, L. 1997. Introduction to the special issue on community-based coastal management. Ocean \& Coastal Management, v. 36, p. 1-9.

HILL, N. A. O.; MICHAEL, K. P.; FRAZER, A.; LESLIE, S. 2010. The utility and risk of local ecological knowledge in developing stakeholder driven fisheries management: The Foveaux Strait dredge oyster fishery, New Zealand. Ocean \& Coastal Management, v. 53, p. 659-668.

JACOBI, P.R. 2000. Politicas Sociais e Ampliação da Cidadania. São Paulo: FGV Editora, $152 \mathrm{pp}$.

JACOBI, P. R.; FRANCO, M. I. G. C. 2011. Sustentabilidade, Participação, Aprendizagem Social. In: JACOBI, P.R. (Org.). Aprendizagem SocialDiálogos e Ferramentas Participativas: Aprender Juntos para Cuidar da Água. São Paulo: IEE/PROCAM, p. 11-21.

JACOBI, P. R.; GIATTI, L.; AMBRIZZI, T. 2015. Interdisciplinaridade e mudanças climáticas: caminhos de reflexão para a sustentabilidade. In: PHILIPPI, A.; FERNANDES, V. (Eds.). Práticas da Interdisciplinaridade no Ensino e Pesquisa. São Paulo: Manole.

JOHANNES, R. E. 1993. Integrating traditional ecological knowledge and management with environmental impact assessment. Traditional ecological knowledge: concepts and cases, p. 33-39.

JUNG, C. A.; DWYER, P.; MINNEGAL, M.; SWEARER, S. 2011. Perceptions of 
environ- mental change over more than six decades in two groups of people interacting with the environment of Port Phillip Bay, Australia. Ocean \& Coastal Management, vol. 54, p. 93-99.

KALIKOSKI, D. C.; SEIXAS, C. S.; ALMUDI, T. 2009. Gestão compartilhada e comunitária da pesca no Brasil: avanços e desafios. Ambiente \& Sociedade, v. 12, p. 151-172.

KELBLE, C. R.; LOOMIS, D. K.; LOVELACE, S.; NUTTLE, W. K.; ORTNER, P. B.; FLETCHER, P.; COOK, G. S.; LORENZ, J. J.; BOYER, J. N. 2013. The EBM-DPSER Conceptual model: Integrating ecosystem services into the DPSIR Framework. Plos ONE, v. 8, e70766.

KRISTENSEN, P. 2004. The DPSIR framework. Workshop on a comprehensive/detailed assessment of the vulnerability of water resources to environmental change in Africa using tiver basin approach. Disponível em:

http://wwz.ifremer.fr/dce/content/download/69291/913220/file/DPSIR.pdf>. Acesso em 30 de junho de 2016.

KNIGHT, R. L.; MEFFE, G. K. 1997. Ecosystem management: agency liberation from command and control. Wildlife Society Bulletin, v. 25, p. 676-678.

LÉVI-STRAUSS, C. 1973. O Pensamento Selvagem. Campinas: Papiros Editora, $323 \mathrm{pp}$.

LUNDBERG, C. 2005. Conceptualizing the Baltic Sea ecosystem: an interdisciplinary tool for environmental desicion making. Ambio, v. 34, p. 433-439.

MALDONADO, S. C. 2000. No mar: conhecimento e produção. Em: Diegues, A. C. (Org.). A Imagem das Águas. São Paulo: Hucitec, p. 95-99.

MALDONADO, W. 2004. A construção material e simbólica da canoa caiçara. Em: DIEGUES, A. C. (org.). Enciclopédia caiçara: o olhar do pesquisador. Vol.1, São Paulo: Editora Hucitec - NUPAUB-CEC/USP, p. 297-320.

MARCONI, M. A.; LAKATOS, E. M. 2003. Fundamentos de metodologia científica. São Paulo: Editora Atlas, 311 pp.

MARQUES, J. G. W. 2001. Pescando Pescadores: Ciência e Etnociência em uma Perspectiva Ecológica. [2a . Ed.] São Paulo: Núcleo de Apoio à Pesquisa sobre Populações Humanas e Áreas Úmidas Brasileiras da USP, 
$258 \mathrm{pp}$.

MARTíNEZ, M. L.; INTRALAWAN, A.; VÁZQUEZ, G.; PÉREZ-MAQUEO, O.; SUTTON, P.; LANDGRAVE, R. 2007. The coasts of our world: Ecological, economic and social importance. Ecological Economics, v. 63, p. 254-272.

MARTINEZ, D. 2012. Representações e percepções sobre ambiente e conservação como subsídio ao Gerenciamento Costeiro Integrado: estudo de caso com grupos sociais da região de Cananéia, litoral sul do Estado de São Paulo. Dissertação. São Paulo. Programa de Pós-graduação em Oceanografia, Universidade de São Paulo, 174pp.

MARTINS, G. A. 1994. Metodologias convencionais e não-convencionais e a pesquisa em administração. Caderno de Pesquisas em Administração, v. 0 , p. 1-6.

MARTINS, V. N.; PIRES, R.; CABRAL, P. 2012. Modelling of coastal vulnerability in the stretch between the beaches of Porto de Mós and Falésia, Algarve (Portugal). Journal of Coastal Conservation, v. 16, p. 503510.

MCALLISTER, K. 1999. Understanding participation: Monitoring and evaluating process, outputs and outcomes. IDRC series. International Development Research Centre, Ottawa. Available at: < https://www.idrc.ca/ > Acessado em: 20 de Junho de 2016.

MEA (MILLENNIUM ECOSYSTEM ASSESSMENT). 2005. Ecosystems and Human Well-being: Synthesis. Washington, D: Island Press, 155 pp.

MEADOWS, D. H.; MEADOWS, D. L.; RANDERS, D. L.; BEHRENS, III. W. W. 1972. The Limits to Growth: A Report for the Club of Rome's Project on the Predcament of Mankind. London: Earth Island Ltd, 205 pp.

MEDEIROS, R. P. 2009. Possibilidades e obstáculos à co-gestão adaptativas de sistemas pesqueiros artesanais: Estudo de caso da área da Baía de Tijucas, Litoral Centro-Norte do Estado de Santa Catarina, no período de 2004 a 2008. Florianópolis: Universidade Federal de Santa Catatina.

MERLEAU-PONTY, M. 1999. Fenomenologia da Percepção [2nd ed.]. São Paulo: Martins Fontes, $662 \mathrm{pp}$.

MORAES, A. X. R. 2007. Contribuições para a gestão da zona costeira do Brasil: elementos para uma geografia do Litoral Brasileiro. São Paulo: 
Annablume, 232pp.

MORAIS, J. M. F. 2008. O Antropoceno: desafios da mudança global. Revista Lusófona de Humanidades e Tecnologias, v. 1, pp. 15-25.

MORAN, E. F. 2008. Nós e a natureza: uma introdução às relações homemambiente. [s.l.] Editora Senac, 304 pp.

MORAN, E. F. O. 2011. Desafio de Pesquisa em Interações Homem-Ambiente. In: Meio Ambiente e Ciências Sociais. São Paulo: Editora Senac, p. 21-53.

MOREIRA, V. 2004. O método fenomenológico de Merleau-Ponty como ferramenta crítica na pesquisa em psicologia. Psicologia: Reflexão e Crítica, v. 17, p. 447-456.

MORIN, E. 2004. Os desafios da complexidade. Em: MORIN, E. (Ed.). A religação dos saberes: o desafio do século XXI. Rio de Janeiro: Bertrand Brasil.

MOURA, G. G. M.; DIEGUES, A. C. S. A. 2009. Os conhecimentos tradicional e científico do Saco do Arraial, estuário da Lagoa dos Patos (RS). Boletim do Instituto de Pesca, v. 35, p. 359-372.

MOURA, G. G. M. 2009. Águas da Coréia: pescadores, espaço e tempo na construção de um território de pesca na Lagoa dos Patos (RS) numa perspectiva etnooceanográfica. Dissertação. São Paulo. Programa de Pósgraduação em Ciências Ambientais, Universidade de São Paulo, 259pp.

MOURA, G. G. M. 2013. Guerras nos mares do Sul: A produção de uma monocultura marítima e os processos de resistência. Doutorado. São Paulo. Programa de Pós-graduação em Ciências Ambientais, Universidade de São Paulo, 410pp.

MOURA, G. G. M.; KALIKOSKI, D. C.; DIEGUES, A. C. S. 2013. A resource management scenario for traditional and scientific management of pink shrimp (Farfantepenaeus paulensis) in the Patos Lagoon estuary (RS), Brazil. Journal of ethnobiology and ethnomedicine, v. 9, p. 1-18.

MOURÃO, J. S.; NORDI, N. 2003. Etnoictiologia de pescadores artesanais do estuário do rio Mamanguape, Paraíba, Brasil. Betim do Instituto de Pesca, v. 29 , p. $9-17$.

MUSSOLINI, G. 1980. Ensaios de Antropologia Indígena e Caiçara. Rio de Janeiro: Paz e Terra, 290 pp. 
NARCHI, N. E.; CORNIER, S.; CANU, D. M.; AGUILAR-ROSAS, L. E.; BENDER, M. G.; JACQUELIN, C.; THIBA, M.; MOURA, G. M. G.; WIT, R. 2014. Marine ethnobiology a rather neglected area, which can provide an important contribution to ocean and coastal management. Ocean \& Coastal Management, v. 89, p. 117-126.

NESS, B.; ANDERBERG, S.; OLSSON, L. 2010. Structuring problems in sustainability science: The multi-level DPSIR framework. Geoforum, v. 41, p. $479-488$.

NETO, P. S. A. 2016. Importância da tutela jurídica das comunidades tradicionais caiçaras. In: Neto, P. S. (Org.) Direito das Comunidades Tradicionais Caiçaras. Editora São Paulo: Café com Lei, p. 21-38.

NORAH, I. P. 2016. Atuação do Estado nas comunidades tradicionais caiçaras. In: Neto, P. S. (Org.) Direito das Comunidades Tradicionais Caiçaras. Editora São Paulo: Café com Lei, p. 49-64.

OGDEN, J. C.; DAVIS, S. M.; JACOBS, K. J.; BARNES, T.; FLING, H. E. 2005. The use of conceptual ecological models to guide ecosystem restoration in South Florida. Wetlands, v. 25, p.795-809.

OLSEN, S. B.; LOWRY, K.; TOBEY, J. 1999. A manual for assessing progress in coastal management Coastal Resources Center, University of Rhode Island, $61 \mathrm{pp}$.

OLSEN, S. B. 2003. Frameworks and indicators for assessing progress in integrated coastal management initiatives. Ocean \& Coastal Management, v. 46, p. 347-361.

ÖSTERBLOM, H.; MARRIE, A.; METIAN, M.; BOONSTRA, W.; WATSON, J.; RYKACZEWSKI, R.; OTA, Y.; SARMIENTO, J.; SCHLÜTER, M.; BIRNBAUM, S.; GUSTAFSSON, B.; HUMBORG, C.; MÖRTH, M.; MÜLLER-KARULIS, B.; TOMCZAK, M; TROELL, M.; FOLKE, C.; BLENCKNER, T. 2013. Modeling Social-Ecological Scenarios in Marine Systems. BioScience, v. 63, p.735-744.

PAES, S. R. 2006. Desenvolvimento global e desenvolvimento local: cultura caiçara no litoral norte de São Paulo. Ciências Humanas em Revista, v. 4, p 153-167.

PERES, C.M. Avaliação da percepção ambiental como ferramenta para análise 
de transformações e impactos sobre o ambiente costeiro: estudo de caso na Enseada do Araçá. Monografia. São Paulo. Título de Bacharelado em Oceanografia, Universidade de São Paulo, 59pp.

PERES, C. M.; XAVIER, L. Y.; SANTOS, C. R.; TURRA, A. 2016. Stakeholders perceptions of local environmental changes as a tool for impact assessment in coastal zones. Ocean \& Coastal Management, v. 119C, p. 135-145.

PETERSON, N. D. 2011. Excluding to include: (Non)participation in Mexican natural resource management. Agriculture and Human Values, v. 28, p. 99107.

PICKTON, D. W.; WRIGHT, S. 1998. What's swot strategic analysis? Strategic Change, v. 7, p. 101-109.

PIMBERT, M. O.; PRETTY, J. N. 2000. Parques, comunidades e profissionais: Incluindo "participação" no manejo de Áreas Protegidas. In: DIEGUES, A. C. (Org.). Etnoconservação: Novos rumos para a proteção da naturea nor trópicos. São Paulo: Annablume, p. 183-224.

PIKITCH, E.; SANTORA, E.; BABCOCK, A.; BAKUN, A. 2004. Ecosystembased fishery management. Science. Disponível em: $<$ http://ecite.utas.edu.au/73153>. Acessado em Julho 2014.

PLDS/Araçá. Plano Local de Desenvolvimento Sus- tentável da Baía do Araçá. 2016. TURRA, A.; SANTOS, C. R.; PERES, C. M.; SEIXAS, S. C.; SHINODA, D. C.; STORI, F. T.; XAVIER, L. Y.; ANDRADE, M. M.; SANTANA, M F. M.; RODRIGUES, M. V.; GRILLI, N. M.; JACOBI, P. R.; SARAFINI, T. Z. (Org.). São Paulo: Instituto Oceanográfico da Universidade de São Paulo, 69 pp.

POLETTE, M.; SILVA, L. 2003. Gesamp, Ican e PNGC - Análise comparativa entre as metodologias de gerenciamento costeiro integrado. Gestão das Águas, v. 55, p. 27-31.

POLETTE, M.; LINS-DE-BARROS, F. 2012. Os desafios urbanos na zona costeira brasileira frente às mudanças climáticas. Costas - Revista Ibero Americana de Manejo Costeiro Integrado, v. 1, p. 165-180.

PONTING, C. 1995. Uma História Verde no Mundo. Rio de Janeiro: Civilização Brasileira, $646 \mathrm{pp}$.

POSEY, D. A. 1987. Introdução - Etnobiologia: teoria e prática. Em: RIBEIRO, 
D. (Ed.). Suma etnológica brasileira. Petrópolis: Vozes/Finep, p. 15-25.

POSEY, D. A. 2001. Interpretando e utilizando a "realidade" dos conceitos indígenas: o que é preciso aprender dos nativos?. In: DIEGUES, A. C.; MOREIRA, A. C. (Org.). Espaços e recursos naturais de uso comum. São Paulo: NAPAUB, p. 279 - 294.

POST, G. C.; LUNDIN, C.G. 1996. Guidelines for integrated coastal zone management. Washington, DC: The World Bank, $28 \mathrm{pp}$.

RADCHENKO, V.; ALEYEV, M. 2000. Environmental and social impacts of management approaches in Sevastopol Bay in a historic retrospective: a case study from the Black Sea. Ocean \& coastal management, v. 43, p. 793-817.

RAMIRES, M.; MOLINA S. M. G.; HANAZAKI, N. 2007. Etnoecologia caiçara: o conhecimento dos pescadores artesanais sobre aspéctos ecológicos da pesca. Biotemas, v. 20, p. 101-113.

RAMIRES, M.; CLAUZET, M.; BARRELLA, W.; ROTUNDO, M. M.; SILVANO, R. A. M.; BEGOSSI, A. 2015. Fishers' knowledge about fish trophic interactions in the southeastern Brazilian coast. Journal of ethnobiology and ethnomedicine, v. 11, p. 1-11.

RESSURREIÇÃO, R.D. 2002. São Sebastião: transformações de um povo caiçara. São Paulo: Editora Humanitas, 256pp.

RHOADS, B.; WILSON, D.; URBAN, M. 1999. Interaction Between Scientists and Nonscientists in Community-Based Watershed Management: Emergence of the Concept of Stream Naturalization. Environmental management, v. 24, p. 297-308.

ROUÉ, M. 2000. Novas perspectivas em etnoecologia: "saberes tradicionais" e gestão dos recursos naturais. In: DIEGUES, A. C. Etnoconservação: Novos rumos para a conservação da natureza. São Paulo: ANNABLUMENUPAUB-HUCITEC, p. 67-80.

ROWE, G.; FREWER, L. J. 2000. Public participation methods: a framework for evaluation. Science, Technology and Human Values, v. 25 p. 3-29.

ROWE, G.; MARSH, R.; FREWER, L. J. 2004. Evaluation of a deliberative conference in science. Science Technology \& Human values, v. 29, $88 \mathrm{e} 121$. 
RUDDLE K. 1998. Traditional community-based coastal marine fisheries management in Viet Nam. Ocean \& Coastal Management, v. 40, p. 1-22.

RUDDLE, K. 2000. Systems of knowledge: dialogue, relationships and process. Environment, development and sustainability, p. 277-304.

SANTOS, B. D. S. 2007. Para além do Pensamento Abissal. Novos Estudos, v. 79, p. 71-94.

SANTOS, C. R.; TURRA, A. (Org.). Rumos da sustentabilidade costeira: Uma visão do Litoral norte. No prelo.

SCHREIBER, E.; BEARLIN, A., 2004. Adaptive management: a synthesis of current understanding and effective application. Ecological Managment \& Restoration, v. 5, p. 177-182.

SEKOVSKI, I.; NEWTON, A.; DENNISON, W. C. 2012. Megacities in the coastal zone: Using a driver-pressure-state-impact-response framework to address complex environmental problems. Estuarine Coastal and Shelf Science, v. 96, p. 48-59.

SERAVAL, T. A. \& ALVES, F. L. 2011. International trends in ocean and coastal management in Brazil. Journal of Coastal Research, SI 64, p. 1258-1262.

SHIRAZAWA-FREITAS, J. 2012. Gestão da zona costeira: políticas públicas e atores sociais na Praia da Cocanha, Caraquatatuba, São Paulo. Dissertação. São Paulo. Programa de Pós-graduação em Oceanografia, Universidade de São Paulo, 115pp.

SLOCOMBE, D. 1998. Defining Goals and Criteria for Ecosystem-Based Management. Environmental management, v. 22, p. 483-93.

SMEETS, E., WETERINGS, R. 1999. Environmental indicators: typology and overview. Technical Report No. 25, p. 1-20.

SORENSEN, J. 1993. The International Proliferation of Integrated Coastal Zone Management Efforts. Ocean \& coastal management, v. 21, p. 45-80.

SOUSA, L. P.; LILLEBØ, A.; GOOCH, G.; SOARES, J.; ALVES, F. 2013. Incorporation of Local Knowledge in the Identification of Ria de Aveiro Lagoon Ecosystem Services (Portugal). Journal of Coastal Research, p. 1051-1056.

SRIVASTAVA, P. K.; KULSHRESHTHA, K.; MOHANTY, C. S.; PUSHPANGADAN, P.; SINGH, A. 2005. Stakeholder-based SWOT 
analysis for successful municipal solid waste management in Lucknow, India. Waste Management, v. 25, p. 531-537.

STEFFEN, W.; SANDERSON, R.; TYSON, P.; JÄGER, J.; MATSON, P.; MOORE, III. B.; OLDFIELD, F.; RICHARDSON, K.; SCHELLNHUBER, H.; TURNER, B.; WASSON, R. 2005. Global change and the earth system: a planet under pressure. [s.l.]: Springer, $336 \mathrm{pp}$.

STORI, F.T. 2010. Adaptatividade e Resiliência no Sistema Socioecológico da Comunidade Caiçara da Ilha Diana, Município de Santos-SP. São Carlos. Doutorado. Programa de Pós-Graduação em Ecologia e Recursos Naturais, Universidade Federal de São Carlos, 239 pp.

STORI, F. T.; ABESSA, D. M. S.; NORDI, N. 2013. Análise das lógicas de ação de atores sociais em torno do licenciamento ambiental de um terminal portuário no estuário de Santos (Brasil). Revista da Gestão Costeira Integrada, v. 13, p. 365-377.

STORI, F.T.; SANTOS, C.R; VIVACQUA, M.; SERAFINI, T.Z., XAVIER, L.Y. GRILLI, M.N.; PERES, C.M.; SHINODA, D.C.; NUNES, F.O.; CARRILHO, C.; SINISGALLI, P.A.A.; JACOBI, P.R.; SEIXAS, C.S.; TURRA, A. 2016. Gestão costeira integrada com vistas à resiliência de sistemas socioecológicos para sustentabilidade dos bens e serviços ecossistêmicos: reflexões de um coletivo. In: Avanços em Oceanografia Humana: o socioambientalismo nas ciências do mar. Org: MOURA, G. Jundiaí: Paco Editorial. No prelo.

TALJAARD, S.; SLINGER, J. H.; MORANT, P. D.; THERON, A. K.; VAN NIEKERK, L.; van der MERWE, J. 2012. Implementing integrated coastal management in a sector-based governance system. Ocean \& Coastal Management, v. 67, p. 39-53.

TAYLOR, R. B.; MORRISON, M.; SHEARS, N. 2011. Establishing baselines for recovery in a marine reserve (Poor Knights Islands, New Zealand) using local ecological knowledge. Biological Conservation, v. 144, p. 3038-3046.

TISSOT, B. N.; WALSH, W. J.; HIXON, M. 2009. Hawaiian Islands Marine Ecosystem Case Study: Ecosystem- and Community-Based Management in Hawaii. Coastal Management, v. 37, p. 255-273.

TSCHERNING, K.; HELMING, K.; KRIPPNER, B.; SIRBER, S.; PALOMA, S. G. 
2012. Does research applying the DIPSIR framework support decision making?. Land and Policy, v. 29, p. 102-110.

TRAN, K. C.; EUAN, J.; LUISA, M. 2002. Public perception of development issues: impact of water pollution on a small coastal community. Ocean \& Coastal Management, v. 45, p. 405-420.

tRenouth, A. L.; HARTE, C.; PETERSON DE HEER, C.; DEWAN, K.; GRAGE, A.; PRIMO, C.; CAMPBELL, M. 2012. Public perception of marine and coastal protected areas in Tasmania, Australia: Importance, management and hazards. Ocean \& Coastal Management, v. 67, p. 19-29.

TURNER, R. K.; LORENZONI, I.; BEAUMONT, N.; BATEMAN, I.; LANGFORD, I.; MCDONALD, A. 1998. Coastal Management for Sustainable Development: Analysing Environmental and Socio-Economic Changes on the UK Coast. The Geographical Journal, v. 164, p. 269-281.

TURRA, A.; PERES, C. M.; SANTOS, C. R. 2015. Histórico da Baía Araçá. In: AMARAL, A. C. Z.; TURRA, A.; CIOTTI, A. M.; WONGTSCHOWSKI, C. L. D. B. R.; SCHAEFFER-NOVELLI, Y. Vida na Baía do Araçá: Diversidade e importância. São Paulo: LUME, p. 18-27.

UNEP. 1972. Report of the United Nations Conference on the Human Environment. Disponível em: <http://http://www.un-documents.net/aconf4814r1.pdf>. Acesso em: 17 de junho de 2016.

UNEP. 1992. Rio declaration on environment and development. Disponível em:<http://www.unep.org/documents.multilingual/default.asp?documentid=7 8\&articleid=1163>. Acesso em: 17 de junho de 2016.

UN. 1982. United Nations Convention on the Law of the Sea. Disponível em: $<$ http://www.un.org/Depts/los/convention_agreements/convention_overview _convention.htm>. Acesso em: 17 de junho de 2016.

UN. 1992. Agenda 21. Disponível em: < http://www.onu.org.br/rio20/img/2012/01/agenda21.pdf>. Acesso em $10 \mathrm{de}$ junho de 2016.

VIANNA, L. P. 2008. De invisíveis a protagonistas: populações tradicionais e unidades de conservação. São Paulo: Annablume, 339 pp.

VIEGAS, M. D. C.; MONIS, A. B.; SANTOS, P. T. 2014. Artisanal fishermen contribution for the integrated and sustainable coastal management - 
application of strategic SWOT analysis. Prodecia: Social and Behavioral Sciences, v. 120, p. 257-267.

VIERTLER, R. V. 2002. Métodos antropológicos como ferramenta para estudos em Etnobiologia e Etnoecologia. In: AMOROZO, M. C. M.; MING, L. C.; SILVA, S. P. (Orgs.). Métodos de Coleta e Análise de Dados em Etnobiologia, Etnoecologia e Disciplinas Correlatas. Anais do Seminário de Etnobiologia e Etnoecologia do Sudeste. 204p. Rio Claro: UNESP/CNPq.

VILLAMARIN, B. C. 2014. Alterações morfológicas da Baía do Araçá: Implicações em sua dinâmica. Monografia. São Paulo. Título de Bacharelado em Oceanografia, Universidade de São Paulo, 59pp.

WEBLER, T.; KASTENHOLKZ, H.; RENN, O. 1995. Public participation in impact assessment: A social lerarning perspective. Environmental Impact Assessment Review, v. 15, p. 443-463.

WESTMACOTT, S. 2001. Developing decision support systems for integrated coastal management in the tropics: is the ICM decision-making environment too complex for the development of a useable and useful DSS? Journal of environmental management, v. 62, p. 55-74.

WEVER, L.; GLASER, M.; GORRIS, P.; FERROL-SCHULTE, D. 2012. Decentralization and participation in integrated coastal management: Policy lessons from Brazil and Indonesia. Ocean \& Coastal Management, v. 66, p. 63-72.

WILLEMS, E. 2003. A llha de Búzios. São Paulo: Hucitec, 185 pp.

WRIGHT, R.; STEIN, M. Snowball sampling. In: Encyclopedia of Social Measurement. [s.l: s.n.].

WORLD OCEAN REVIEW (WOR). 2015. Sustainable Use of Our Oceans Making Ideas Work volume 4. Hamburg: Maribus, $151 \mathrm{pp}$.

XAVIER, L. Y. 2010. Participação de comunidades de pescadores tradicionais na elaboração de políticas públicas para a zona costeira: Um estudo de caso sobre o Zoneamento Ecológico-Econômico Marinho no Litoral Norte de São Paulo. Dissertação. São Paulo. Programa de Pós-graduação em Oceanografia, Universidade de São Paulo, $191 \mathrm{pp}$.

XAVIER, L. Y.; TURRA, A. 2013. Entendendo os problemas socioambientais: passos para construir a Agenda 21 Local. In: JACOBI, P. R.; XAVIER, L. Y.; 
MISATO, M. T. (Org.). Aprendizagem social e unidades de conservação: aprender juntos para cuidar dos recursos naturais. São Paulo: IEE/PROCAM, p. 57-62.

ZAGONARI, F. 2008. Integrated coastal management: Top-down vs. community-based approaches. Journal of environmental management, $v$. 88, p. 796-804. 


\section{ANEXO 1 - Questionário semiestruturado}

ENTREVISTA SEMIESTRUTURADA ETNO/RESILIÊNCIA UNIVERSIDADE DE SÃO PAULO - INSTITUTO OCEANOGRÁFICO -

LabManejo

PROJETO BIOTA ARAÇÁ - FAPESP.

DATA: № do Questionário

1)Nome:

Apelido

2) Contato (telefone, endereço, e-mail):

3) Sexo: [ ] Masculino [ ] Feminino

4) Idade:

5) Religião: [ ] Católica [ ] Evangélica [ ] Espírita [ ] Outra

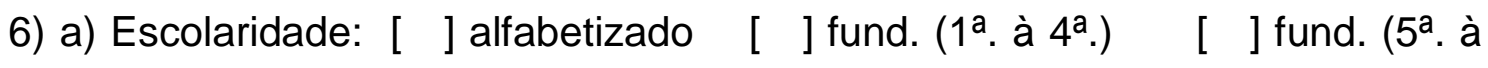
8. ${ }^{\text {.) }}$ [ ] médio incompleto

[ ] médio completo [ ] sup. incompleto [ ] sup. completo [ ] nível técnico

b) Freqüenta escola atualmente? [ ] Sim [ ] Não

Obs:

7) Fonte de renda principal:

e secundária: 
8) Considerando o valor de um salário mínimo ( $S M=724$ reais) qual é a sua renda: [ ] Sem renda [ ] até 2

[ ] 2-4 [ ] 4-10 [ ] 10-20 [ ] + de 20

Obs:

9)Local de Nascimento:

UF:

10) a) Há quanto tempo reside nesta região?

b) Por que você mora nesta região?

c) O que você acha de morar nesta região? Por quê?

d) Você quer continuar morando nesta região? [ ] Sim [ ] Não Por quê?

e) O que o levaria a mudar-se desta região? Para onde você iria?

11) Você se considera um caiçara?

12) O que tem de bom na Baía do Araçá?

13) O que tem de ruim?

14) Qual a importância do Araçá?

15) Pense no território do Araçá. Fale sobre as mudanças que você presenciou neste território.

16) Fale mais sobre a pesca Baía da Araçá:

a) Você acha que a pesca mudou de uns tempos pra cá? [ ] Sim [ ] Não

b) O que mudou?

c) O que causou esta(s) mudança(s)?

d) Em que época(s) esta(s) mudança(s) foi percebida?

e) Foi feito alguma coisa para mudar essa situação? O quê?

f) O que você acha que vai acontecer com a pesca na Baía do Araçá no futuro?

g) O que você faria se a pesca acabasse na Baía do Araçá? 
17) a) Com quantos anos começou a pescar/catar?

b) Com quem aprendeu?

c) Vc já ensinou alguém a pescar/catar? [ ] Sim [ ] Não Quem?

18) Com que freqüência você pesca/cata? [ ] Todo dia. vezes/semana. Outro

19) Qual área aqui dentro da Baía é importante para produção de pescado? Indicar no mapa.

20) Diga mais sobre as pescarias que você realiza (preencher tabela de pesca):

a) O que você pesca/cata e como?

b) Quais são as melhores épocas do ano para pescar/catar essa espécie?

c) Em que condições é melhor de pescar/catar essa espécie?

d) Como você escolhe o local que vai pescar/catar? Indicar no mapa os locais de pesca.

e) Por que este recurso existe nestes locais? O que faz ter este recurso nestes lugares?

TABELA DE PESCA: Descrição das pescarias realizadas pelo entrevistado (pergunta 20 do questionário).

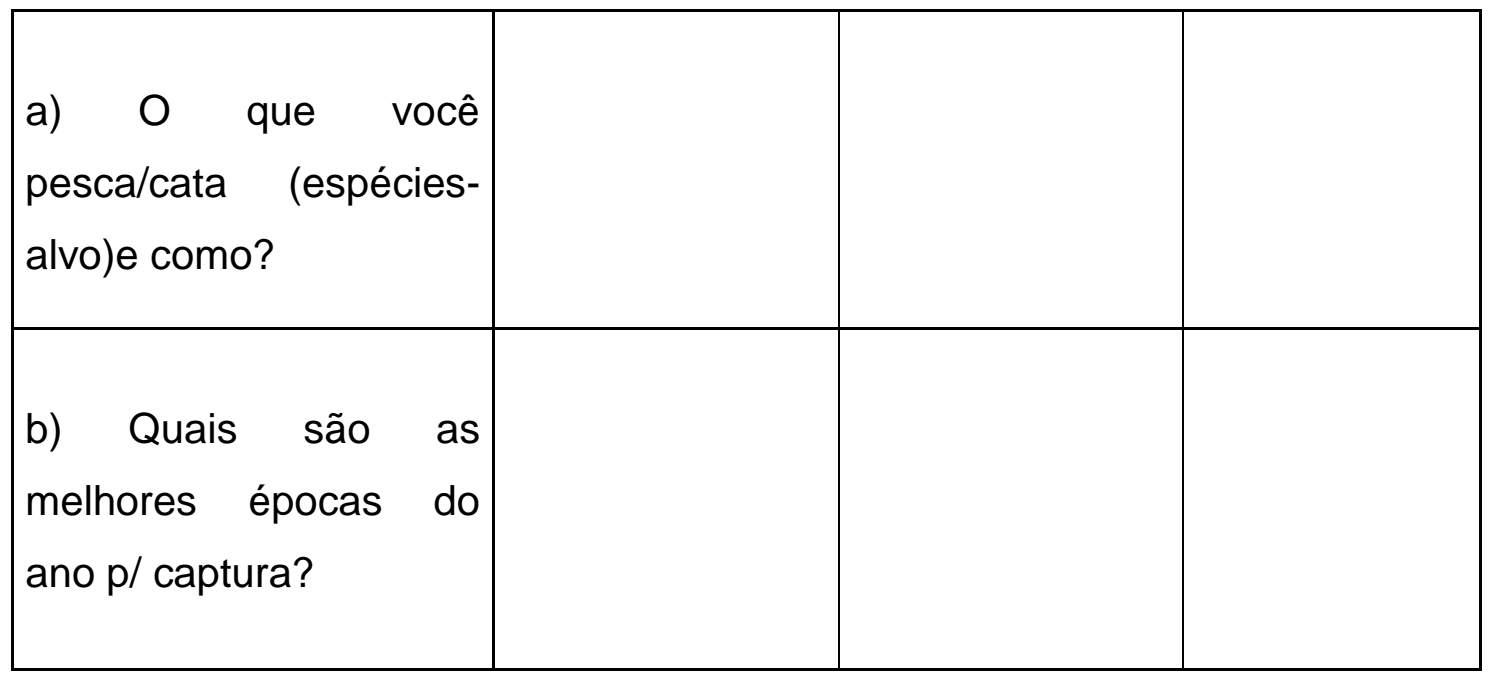




\begin{tabular}{|l|l|l|l|}
\hline $\begin{array}{l}\text { c) Em que condições é } \\
\text { melhor p/ capturar? }\end{array}$ & & & \\
\hline $\begin{array}{l}\text { d) Como você escolhe o } \\
\text { local que vai } \\
\text { pescar/catar?(Mapa) }\end{array}$ & & & \\
\hline $\begin{array}{l}\text { e) Por que este recurso } \\
\text { existe nestes locais? O } \\
\text { que faz ter ele nestes }\end{array}$ & & & \\
lugares? & & & \\
\hline
\end{tabular}

21) Você acha que deveria ter alguma área fechada para pesca?

a) Se sim, onde e por quanto tempo? Indicar no mapa.

22) a) Você possui alguma embarcação? [ ] Sim [ ] Não

b) Mostre no mapa onde voce a estaciona.

c) Por que você deixa ela neste lugar? O que torna este lugar bom para deixar sua embarcação?

23) Você compartilha?

a) embarcação [ ] $\operatorname{Sim} \quad$ [ ] Não Nom quem?

b) petrechos [ ] Sim [ ] Não Com quem?

c) locais de pesca [ ] Sim [ ] Não Com quem?

24) Existem regras entre os pescadores do Araçá? [ ] Sim [ ] Não 
Quais?

25) a) Você e sua família praticam alguma atividade de lazer e recreação aqui?

[ ] Sim [ ] Não

b) O quê? Onde? Mostre no mapa onde voce pratica esta atividade.

c) $O$ que faz deste lugar um bom lugar para tal prática (processos/funcionamento)?

26) Tem alguma área importante para a pesca e lazer que não poderia ser perdida-eliminada?

27) Como você acha que vai ser o futuro da Baía do Araçá? Por quê?

28) a) Como você gostaria que fosse o futuro da Baía do Araçá?

b) O que teria e o que não teria neste futuro? Por quê?

29) O que é preciso fazer para que a Baía do Araçá se torne um lugar melhor?

30) a) Quem você considera responsável por estas ações?

b) Você acha que há organização das pessoas da região neste sentido? [ ] Sim [ ] Não

31) a) Você participa de alguma associação comunitária? [ ] Sim [ ] Não Qual?

b) Desde quando?

c) Como é a sua participação-envolvimento?

32) O que você faz para contribuir com a melhoraria da Baía do Araçá?

33) O que você poderia fazer para contribuir com a melhoraria da Baía do Araçá?

34) a) Você conhece ou já ouviu falar da Política que trata do Gerenciamento 
Costeiro do LN (GERCO) que fez Zoneamento Marinho? [ ] Sim [ ] Não

b) Do que ela trata?

c) Qual sua opinião a respeito?

d) Participou do trabalho que foi feito até 2004? [ ] Sim [ ] Não

e) Se não participou por quê?

f) Acompanha - participa atualmente? [ ] Sim [ ] Não

g) Se não participou por quê?

h) Se participou, quais sugestões vc deu?

35) a) Você conhece ou já ouviu falar da APAMLN? [ ] Sim [ ] Não

b) Do que ela trata?

c) Qual sua opinião a respeito?

d) Acompanha-participa do trabalho do Plano de Manejo que está sendo feito?

[ ] Sim [ ] Não

e) Se não, por quê?

f) Se sim, quais sugestões vc deu?

36) Poderia indicar outras pessoas envolvidas na pesca aqui no Araçá que seriam importantes para conversar? Por que você indicou esta(s) pessoa(s)? 


\section{ANEXO 2 - Termo de consentimento}
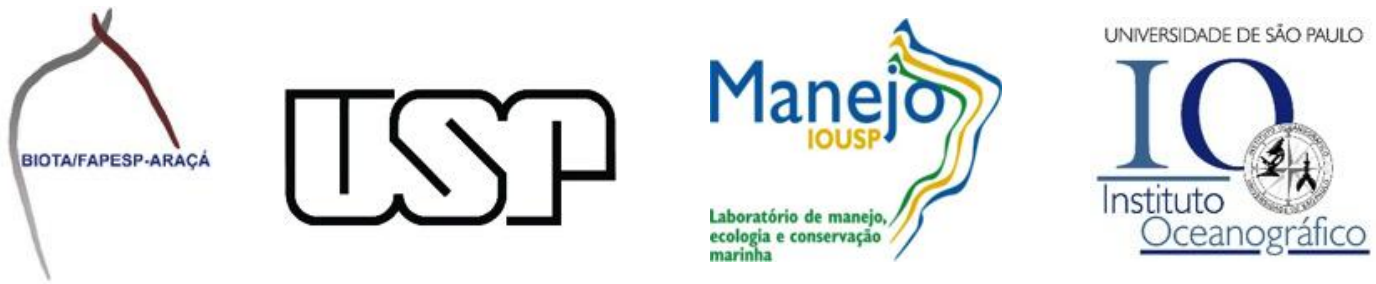

TERMO DE CONSENTIMENTO LIVRE E ESCLARECIDO

Nome: Sr. (Sra.)

Idade: Sexo:

Declaro que fui informado sobre a pesquisa "Gerenciamento Costeiro Integrado sob uma perspectiva Etno-ocenográfica: o Conhecimento tradicional na Enseada do Araçá" (Projeto "Biodiversidade e funcionamento de um ecossistema costeiro subtropical: subsídios para a gestão integrada", Módulo 10: Gestão Integrada); realizada pelo Laboratório de Manejo, Ecologia e Conservação Marinha do Departamento de Oceanografia Biológica do Instituto Oceanográfico da Universidade de São Paulo.

Pelo fato desta pesquisa ter única e exclusivamente um interesse científico, a mesma foi aceita espontaneamente pelo (a) senhor (a) que poderá desistir a qualquer momento, inclusive sem nenhum motivo, bastando para isso informar da maneira mais conveniente a sua desistência. Por ser voluntário (a) e sem interesse financeiro, o (a) senhor (a) não terá direito a nenhuma remuneração. Os dados referentes ao senhor (a) serão sigilosos e privados, e a divulgação do resultado visará apenas os possíveis benefícios obtidos pela pesquisa em questão, sendo que o (a) senhor (a) poderá solicitar informações durante todas as fases desta pesquisa, inclusive após a publicação da mesma.

de de 
ANEXO 3 - Mapa da Baía do Araçá contendo apenas a linha de costa

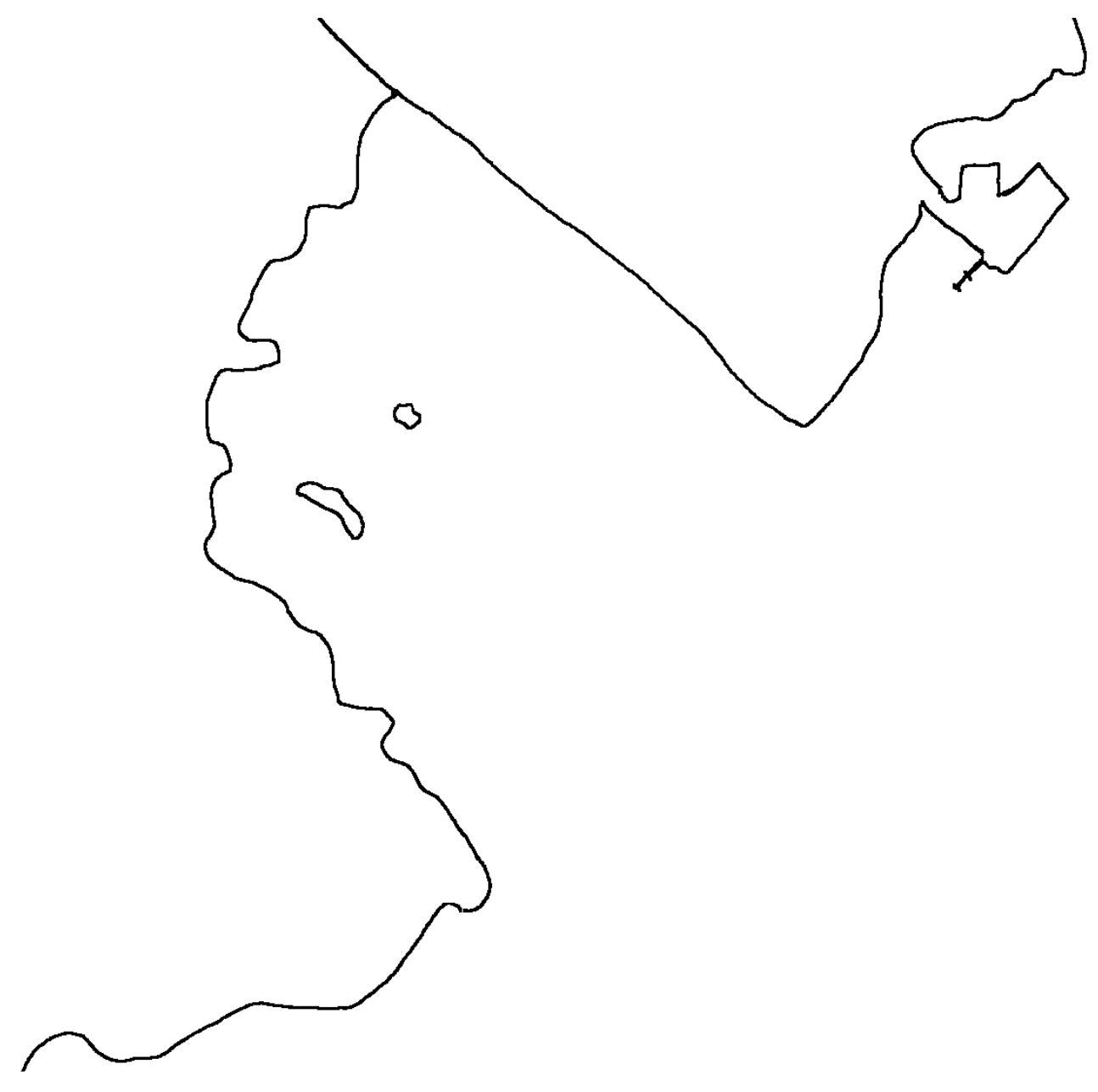

